\title{
Patterns of spatio-temporal paraglacial response in the Antarctic Peninsula region and associated ecological implications
}

\author{
Jesús Ruiz-Fernández ${ }^{1}$, Marc Oliva ${ }^{2}$, Daniel Nývlt ${ }^{3}$, Nicoletta Cannone ${ }^{4}$, Cristina \\ García-Hernández ${ }^{1}$, Mauro Guglielmin ${ }^{5}$, Filip Hrbáček ${ }^{3}$, Matěj Roman ${ }^{3}$, \\ Susana Fernández ${ }^{6}$, Jerónimo López-Martínez ${ }^{7}$, Dermot Antoniades ${ }^{8}$
}

${ }^{1}$ Department of Geography, University of Oviedo, Oviedo, Spain.

${ }^{2}$ Department of Geography, University of Barcelona, Barcelona, Spain.

${ }^{3}$ Department of Geography, Masaryk University, Brno, Czech Republic.

${ }^{4}$ Department of Science and High Technology, Università degli Studi dell'Insubria, Varese, Italy.

${ }^{5}$ Department of Theoretical and Applied Sciences, Università degli Studi dell'Insubria, Varese, Italy.

${ }^{6}$ Department of Geology, University of Oviedo, Oviedo, Spain.

${ }^{7}$ Department of Geology and Geochemistry, University Autónoma of Madrid, Madrid, Spain.

${ }^{8}$ Department of Geography \& Centre for Northern Studies (CEN), Université Laval, Canada

\section{Corresponding author}

Jesús Ruiz-Fernández, ruizjesus@uniovi.es

Department of Geography, University of Oviedo

C/ Amparo Pedregal s/n, Oviedo, 33011, Spain

Tel: +34 985104406 


\begin{abstract}
The Antarctic Peninsula (AP) constitutes the warmest region of Antarctica, although $98 \%$ of the surface is still covered by glaciers. The region shows contrasting geographic and climatic properties, which have conditioned past and present glacial activity. This paper constitutes a review of the spatial and temporal patterns of paraglacial activity across the AP bridging the geomorphological and ecological perspectives. The number and extent of ice-free environments has increased since the Last Glacial Maximum, particularly during the Early Holocene and the $20^{\text {th }}$ century. Following deglaciation, the redefinition of coastlines and the uplift of landmasses proceeded differently in the three sectors of AP, with maximum uplift in the western sector (40 $\mathrm{m}$ a.s.1.), the minimum on the north (20.4 $\mathrm{m}$ a.s.1.), and intermediate in the eastern sector $(30 \mathrm{~m})$. There are also differences in the levels of raised beaches, with the highest complexity in the northern AP (5-7 levels) and the lowest in the eastern AP (3 levels). The transition from glacial to periglacial conditions (paraglacial stage) also differed greatly between the three sectors, with the absence of rock glaciers in the western sector, the development almost exclusively of glacier-derived rock glaciers in the eastern AP, and the majority of talus-derived rock glaciers in the northern AP. The development of protalus lobes, block streams and other periglacial features was highly dependent on the cold/warm based character of individual glaciers; this characteristic determines the existence or absence of permafrost following deglaciation which, in turn, conditions the type and intensity of geomorphic processes in newly exposed ice-free areas. More recently, following the post-1950s regional warming, there have still been important differences between the three sectors in the development of paraglacial environments. Permafrost degradation has occurred in newly exposed areas, accelerating mass wasting and sediment redistribution and changing hydrological processes, especially in the northern and western AP, while sudden glacial outburst flooding has occurred in the eastern AP. The most apparent major ecological response to this recent warming is greening due to vegetation expansion, which is more evident where paraglacial and periglacial processes are less intense. The accurate characterization of the different paraglacial responses existing in the AP enables a better understanding of future environmental responses in this climatically sensitive region, where climate models forecast significant environmental change for during forthcoming decades.
\end{abstract}

Key words: Antarctic Peninsula, deglaciation, paraglacial processes, geomorphology, permafrost, ecology. 


\section{Introduction}

The Antarctic Peninsula (AP) is one of areas on Earth most dramatically affected by climate warming during the recent past, with rates of temperature increase of 0.1 to $0.5^{\circ} \mathrm{C} /$ decade between the $1950 \mathrm{~s}$ and early $21^{\text {st }}$ century (Vaughan et al., 2003; Turner et al., 2005, 2014). However, a reversion of the AP warming trend has been observed from $1998-1999$ to the present, during which time a $-0.47^{\circ} \mathrm{C} / \mathrm{dec}$ de cooling has been observed across the AP, with the exception of the region's NE fringe where the air temperature trend remained positive (Turner et al., 2016; Oliva et al., 2017a).

Besides significant impacts on AP cryospheric processes such as the retreat of ice shelves and sea ice (Cook \& Vaughan, 2010; Davies et al., 2012a), this warming has driven glacial shrinking (Cook et al., 2016), exposing new ice-free areas in coastal fringes of the AP and surrounding islands (e.g. Oliva \& Ruiz-Fernández, 2015). Following glacial retreat, these new ice-free environments are subject to very active geomorphological dynamics, with intense readjustment and sediment redistribution caused by rapid mass movements (mudflows, debris flows, landslides, rock avalanches, etc.) and widespread, slow periglacial processes, such as solifluction (Oliva \& Ruiz-Fernández, 2015). These processes are enhanced in many areas by the existence of permafrost (Vieira et al., 2010; López-Martínez et al., 2012; Bockheim et al., 2013; Oliva \& Ruiz-Fernández, 2015). In proglacial environments, intense sediment redistribution can affect the seasonal fluvial network and even generate anastomosed streams in relatively flat areas (Mink et al., 2014).

Glacial retreat in the AP region is a long-term process associated with the warming trend observed since the Last Glacial Maximum (LGM) and throughout the Holocene, with the exception of limited readvances at certain times (Ingólfsson et al., 2003; Simms et al., 2011; Balco et al., 2013; Ó Cofaigh et al., 2014). Glacial shrinking has led to the exposure of nunataks and coastal areas subjected to longterm paraglacial dynamics such as: (i) glacio-isostatic response, with the development of raised beaches and other raised marine features in coastal environments (Fretwell et al., 2010; Roberts et al., 2011; Watcham et al., 2011), and (ii) soil development and colonization of these environments by wildlife and flora following glacial retreat (Michel et al., 2014; Ruiz-Fernández et al., 2017).

All processes triggered in response to glacial retreat at different temporal and spatial scales are framed within a paraglacial context (Mercier, 2008; Mercier \& Etienne, 2008). The paraglacial concept includes readjustments related to the exposure of new ice-free terrain generated by glacial retreat (Ballantyne, 2002). Paraglacial responses in natural ecosystems can last for hundreds or even thousands of years, with very intense activity during an early stage and a gradual decline in intensity until a certain geomorphological equilibrium is reached (Ballantyne, 2008).

The study of paraglacial dynamics has taken place in numerous locations, but has been largely confined to Alpine regions (e.g. Owen \& Sharma, 1998; Palacios et al., 1999; Iturrizaga, 2008; KellererPirklbauer et al., 2010; Ballantyne \& Stone, 2013). The study of paraglacial processes in polar regions, by contrast, has received less attention (e.g. Fitzsimons, 1996; Mercier \& Laffly, 2005; Rachlewicz, 2010; Francelino et al., 2011), especially in Antarctica where the only existing studies have focused on the AP region (Davies et al., 2013; Oliva \& Ruiz-Fernández, 2015). Our understanding of paraglacial activity in this region is therefore still poorly developed, only examined in specific areas and mostly considered laterally to studies focused on different research topics such as glacial chronology, periglacial processes and glacio-isostatic rebound, among others.

The main objective of this review is to identify, characterize and delineate spatially and temporally the type, magnitude and intensity of paraglacial dynamics in the AP and neighboring islands. This synthesis will enable a better understanding of the possible response of polar maritime environments to the 
temperature increase of up to $3.2^{\circ} \mathrm{C}$ by 2100 predicted for the whole Antarctic continent (IPCC, 2014) that will generate new ice-free areas that will be subject to intense paraglacial dynamics.

\section{Regional setting}

The AP region constitutes the northernmost part of the Antarctic continent between latitude $62^{\circ} \mathrm{S}$ and $75^{\circ} \mathrm{S}$ and longitude $55^{\circ} \mathrm{W}$ and $75^{\circ} \mathrm{W}$ (Figures 1 and 2). The AP region includes several islands and archipelagos, encompassing a total surface of $\sim 540,000 \mathrm{~km}^{2}$. Up to $98 \%$ of the AP region is covered by

glaciers, with the ice-free areas representing an area estimated between 3,800 and 7,000 $\mathrm{km}^{2}$ located mainly in small, deglaciated coastal environments, rocky outcrops and nunataks (Antarctic Digital Database; Burton-Johnson, 2016).

Figure 1

The AP region recorded one of the most pronounced warming rates on Earth during the second half of the $20^{\text {th }}$ century (Turner et al., 2005, 2014), with overall mean annual air temperature (MAAT) increases between 0.8 and $3.0^{\circ} \mathrm{C}$ between 1950 and 2015 (Oliva et al., 2017a). Generally, the climate of the AP region is strongly affected by the orographic barrier of the AP mountain ridge. The western part of the AP is influenced by wet polar-maritime climates, with MAAT between $-2^{\circ} \mathrm{C}\left(65^{\circ} \mathrm{S}\right)$ and -8 to $-9^{\circ} \mathrm{C}$ $\left(70^{\circ} \mathrm{S}\right)$, while a semi-arid polar continental climate prevails in the eastern AP, with MAAT between -6 to $-9^{\circ} \mathrm{C}\left(65^{\circ} \mathrm{S}\right)$ to -13 to $-15^{\circ} \mathrm{C}\left(70^{\circ} \mathrm{S}\right)(\mathrm{Cook} \&$ Vaughan, 2010). Precipitation is estimated between 500 and $2000 \mathrm{~mm}$ w.e. $\cdot \mathrm{yr}^{-1}$ in the western AP and the northern AP, while 100 to $500 \mathrm{~mm}$ w.e. $\cdot \mathrm{yr}^{-1}$ is modelled in the eastern AP (van Lipzig et al., 2004).

Figure 2

Local topographical conditions, together with long-term climate trends since the LGM, have conditioned glacial retreat of ice sheets, ice caps and alpine glaciers across the AP region. Glacial retreat has triggered a wide range of geomorphological processes that have reshaped coastlines as well as terrestrial ecosystem dynamics. Glacial shrinking favored glacio-isostatic processes and the formation of coastal lagoons and raised beaches (Fretwell et al., 2010; Watcham et al., 2010), and promoted the appearance of lakes in the region as meltwater accumulated in surface depressions (Toro et al., 2007; Nedbalová et al., 2013) as well as a redistribution of water runoff in ice-free areas (Mink et al., 2012). Postglacial environmental dynamics favored the extension of permafrost across most of the region; this permafrost plays a major role in geomorphic dynamics in ice-free areas (Vieira et al., 2010; Bockheim et al., 2013). The permafrost distribution in the western AP is mostly discontinuous, with maximum thicknesses around $100 \mathrm{~m}$, while it is continuous in all areas of the eastern AP, with thicknesses of up to $200 \mathrm{~m}$ (Bockheim et al., 2013). The thickness of the active layer is highly variable, ranging between $\sim 30$ and $500 \mathrm{~cm}$ in the western AP and between 20 and $150 \mathrm{~cm}$ in the eastern AP (Vieira et al., 2010; Bockheim et al., 2013). The presence of permafrost and the active layer, together with enhanced water availability in summer, generate drainage above the permafrost table, contributing to surface flow, with potential geomorphological and ecological consequences (Moreno et al., 2012).

With the purpose of examining paraglacial activity in the AP region, in this review we have divided the AP into three different regions based on geographical and climatic criteria:

- The western AP: including the areas from $62^{\circ} \mathrm{S}$ to $75^{\circ} \mathrm{S}$ on the western side of the AP.

- The eastern AP: including the areas from $62^{\circ} \mathrm{S}$ to $75^{\circ} \mathrm{S}$ on the eastern side of the AP.

- The northern AP and surrounding areas, including the northern tip of the AP as well as archipelagos including the South Shetland Islands $\left(62^{\circ} \mathrm{S}\right)$ and islands located further north up to latitude $60^{\circ} \mathrm{S}$ (Elephant Island, Signy Island, etc.). 


\section{Glacial evolution of the AP region}

Cenozoic Antarctic glaciations developed in response to cooling at the Eocene/Oligocene boundary at $\sim 34 \mathrm{Ma}$ (Davies et al., 2012b), and have generally been driven by Milankovitch's orbital forcing (Raymo et al., 2006; Naish et al., 2009). Recurring waxing and waning of the AP Ice Sheet and smaller AP ice caps during the Neogene provided ideal conditions for the operation of paraglacial processes, which modified deglaciated terrestrial landscapes during the relatively shorter interglacial periods (Ballantyne, 2002; Hepp et al., 2006; Nývlt et al., 2011). The importance of the interplay between glacial and paraglacial processes in sculpting landscapes of the AP and adjacent South Atlantic islands has already been suggested by Gordon et al. (1978) in South Georgia and further discussed by Davies et al. (2013) for James Ross Island. The configuration of AP ice cover at the LGM and during the last deglaciation were recently summarized by Ó Cofaigh et al. (2014). Owing to the great variability in the timing and pattern of deglaciation across the AP region (Ó Cofaigh et al., 2014) and the important implications of the expansion of ice-free terrestrial surfaces for paraglacial development of postglacial landscapes (Davies et al., 2013), we present a brief regional overview of the current state of knowledge of AP deglaciation.

\subsection{The eastern AP region}

Recent studies on the configuration of the AP Ice Sheet, which at the LGM also covered the NW Weddell Sea continental shelf as well as islands of the James Ross Archipelago, clearly demonstrate great spatial variability in the timing of deglaciation and its dependence on local topography (Johnson et al., 2011; Davies et al., 2012b; Glasser et al., 2014; Nývlt et al., 2014; Ó Cofaigh et al., 2014; Minzoni et al., 2015). Two ice domes developed in southern Palmer Land, in the southeast AP, with similar configurations to those now present, i.e. radially flowing away from the AP's central spine (Ó Cofaigh et al., 2014). Geological data, including erratics associated with (presumably LGM) trimline on nunataks in Palmer Land and erratic boulders on James Ross Island, indicate ice sheet thickening of at least 400-600 $\mathrm{m}$ in the eastern AP at the LGM (Bentley et al., 2006, 2010; Glasser et al., 2014).

The retreat of the AP Ice Sheet from the outer shelf of the eastern AP starting at $\sim 18.5$ ka (Heroy \& Anderson, 2007) was characterized by re-advances and changes in ice flow direction (Davies et al., 2012b; Campo et al., 2017). The first prominent ice front retreat, associated with meltwater pulse 1A, occurred at 14.5-14.0 ka BP (Weaver et al., 2003). Grounded ice was replaced by floating ice shelves around James Ross Island between 13.3 and 10 ka BP (Pudsey \& Evans, 2001; Nývlt et al., 2014; Minzoni et al., 2015), following rapid regional warming and the Early Holocene optimum when atmospheric temperatures were higher than at present (Mulvaney et al., 2012). The opening of modern fjords and channels occurred between 12 and 10 ka (Domack et al., 2005; Evans et al., 2005; Nývlt et al., 2014; Minzoni et al., 2015), and the remaining ice cover on the individual islands of James Ross Archipelago separated from the AP Ice Sheet and continued in independent development (Johnson et al., 2011; Glasser et al., 2014; Nývlt et al., 2014). Together with a rapid glacial isostatic uplift of individual islands of the James Ross Archipelago (see section 5.1.), this led to the deglaciation of lowlying areas (<100 m a.s.l.) of James Ross Island by 13-11 ka (Glasser et al., 2014; Nývlt et al., 2014); these were thus the areas exposed to paraglacial processes for the longest time.

Grounded ice reached its present configuration by 10 ka BP (Ó Cofaigh et al., 2014). Early-Mid Holocene warmth caused further thinning and retreat of ice caps and glaciers (e.g. Balco et al., 2013), as well as break-up of the Prince Gustav Channel and Larsen-A ice shelves (Brachfeld et al., 2003; Pudsey et al., 2006, Sterken et al., 2012). The mid-altitude areas of James Ross Archipelago (100-300 $\mathrm{m}$ a.s.1.) deglaciated between 8 and $6.3 \mathrm{ka}$ (Johnson et al., 2011; Glasser et al., 2014), but the higherlying surfaces of volcanic mesas ( $>600 \mathrm{~m}$ a.s.l.) were rarely ice-free and persisted under glacier cover even during interglacial periods since their Pliocene formation (Johnson et al., 2009). This corresponds 
well with the present equilibrium line altitude, which lies between 311 and $393 \mathrm{~m}$ a.s.l. for small glaciers of northern James Ross Island (Engel et al., 2018). At least one climatic deterioration, between 5 and 2 ka BP (Björck et al., 1996, Barbara et al., 2016), however, brought glacier advances and some ice shelf reformation during the Neoglacial (Pudsey et al., 2006, Davies et al., 2013). Nonetheless, much younger ages for Neoglacial advances $(<0.5 \mathrm{ka})$ are assumed in case studies from northern James Ross Island (Carrivick et al., 2012; Davies et al., 2014). Gradual warming of the AP region greatly accelerated only over the past century (Cook et al., 2005), causing ice mass loss (Zwally et al., 2015; 2018) and disintegration of ice shelves (Glasser \& Scambos, 2008), and the recent collapse (March 2002) of the Larsen-B Ice Shelf is possibly unprecedented in the Holocene (Domack et al., 2005). Ice unloading in the sector of Robertson Trough has caused glacioisostatic rebound up to $\sim 40 \mathrm{~mm} \mathrm{yr}^{-1}$ in the $21^{\text {st }}$ century (Nield et al., 2014).

\subsection{The western AP region}

A wealth of data from glaciomarine sediments and submarine geomorphological and seismic mapping indicate that the grounded AP Ice Sheet extended to the continental shelf edge of the AP in the Bellingshausen Sea at the LGM (e.g. Heroy \& Anderson 2005; Amblas et al., 2006; Graham \& Smith, 2012). The troughs carved by fast-flowing, erosive ice hosted the Biscoe, Adelaide, Anvers-Hugo Island, Smith and Marguerite Trough paleo-ice streams (Livingstone et al., 2012). Separate ice caps formed on the islands along the western AP coast, including Alexander, Brabant and Anvers islands (Canals et al., 2000; Graham and Smith, 2012; Figures 2A and 2B). The AP Ice Sheet and ice caps were generally 500-650 $\mathrm{m}$ thicker than today and progressive thinning had already started before the LGM, e.g. in the Marguerite Bay region (Bentley et al., 2006; Johnson et al., 2012).

The AP Ice Sheet retreated from the western continental shelf break relatively rapidly after $18 \mathrm{ka}$ BP, firstly in the north and subsequently the lift-off of grounded ice progressed southwards (Heroy \& Anderson, 2007; Ó Cofaigh et al., 2014). The outer Smith and Anvers troughs were thus ice-free earliest, before $\sim 16.5 \mathrm{ka} \mathrm{BP}$, whereas the deglaciation of outer Marguerite, Charcot and Rothschild troughs commenced after $\sim 15$ ka BP (Heroy \& Anderson, 2007; Kilfeather et al., 2011; Graham \& Smith, 2012). Paleo-ice streams experienced rapid but highly variable, topographically controlled retreat and thinning, in contrast to shallower inter-ice stream banks that may have maintained grounded ice longer (Livingstone et al., 2012). Similarly, grounding zone wedges documenting stillstands and episodic advances contrast with the most rapid phases of retreat that coincided with sudden sea-level rises or global meltwater pulses 1A and 1B at $\sim 14$ and $\sim 11$ ka BP, respectively (Heroy \& Anderson, 2007; Kilfeather et al., 2011; Jamieson et al., 2012). Terrestrial data, such as exposure ages from the Batterbee Mountains and Citadel Bastion, located on both sides of George VI Sound, reveal the ongoing thinning of the AP Ice Sheet to 350 and $500 \mathrm{~m}$ a.s.l. by $12.7 \mathrm{ka}$ BP (Bentley et al., 2006). Furthermore, several lacustrine sedimentary records from islands adjacent to Marguerite Bay constrain the deglaciation of terrestrial environments in this sector of the western AP to the Early Holocene (Roberts et al., 2008, 2009; Hodgson et al., 2009, 2013). Lakes on Horseshoe Island were deglaciated 10.6 ka BP (Hodgson et al., 2013), whereas Parvenu Point on Pourquoi-Pas Island became ice-free by 9.6-8.8 ka BP (Bentley et al., 2011; Hodgson et al., 2013) (Figure 2B).

The AP Ice Sheet reached the present-day western coastline of the AP by 7-9 ka BP, following the Early Holocene climatic optimum, and later than in the eastern AP (Bentley et al, 2009, 2011; Ó Cofaigh et al., 2014). Open sea conditions occurred in King George Bay for a brief period in the Early Holocene, as the George VI Ice Shelf collapsed around $~ 9.6 \mathrm{ka} \mathrm{BP}$ and reformed at $\sim 7.7 \mathrm{ka} \mathrm{BP}$, after which it has persisted until the present day (Bentley et al., 2005b). Changes in the position of the Southern Westerlies and the intrusion of warm Circumpolar Deep Water onto the AP shelf are considered to be responsible 
for these thermal optima and glacier recessions, the latter in particular driving submarine ice-shelf melting (Bentley et al, 2009; Shevenell et al., 2011). Neoglacial cooling is registered in Palmer Deep starting at $\sim 3.4 \mathrm{ka} \mathrm{BP}$, and culminating $\sim 100 \mathrm{yr}$ BP at the end of the Little Ice Age (LIA) (Domack et al., 2001). Since the $20^{\text {th }}$ century, rapid glacier recession has occurred, mainly due to ocean-induced melting, and has further accelerated after AD 1990 with increasing inflow of Circumpolar Deep Water onto the western AP continental shelf south of $65^{\circ} \mathrm{S}$ (Cook et al., 2016; IMBIE team, 2018).

\subsection{The northern AP region and surrounding areas}

An independent, largely marine-based ice cap centered between Robert and Greenwich islands with a minimum thickness of 570-1000 m covered the South Shetland Islands and reached the continental shelf edge to the north at the LGM (Canals et al., 2000; Fretwell et al., 2010; Simms et al., 2011). Bransfield Strait was probably occupied by an ice shelf throughout the LGM and well into the Holocene (until $\sim 10 \mathrm{ka} \mathrm{BP}$ ), as this was a major focal point of converging paleo-ice streams from the South Shetland Islands and Trinity Peninsula (Simms et al., 2011; Livingstone et al., 2012). The paleo-ice streams occupied Lafond, Laclavere, Mott Snowfield and Orleans troughs, draining into the central Bransfield Basin and the Gerlache-Boyd Trough, flowing into the western Bransfield Basin and further to Boyd Strait (Livingstone et al., 2012; Davies et al., 2012b).

The earliest evidence of ice sheet recession from the shelf break for the entire AP region is found in the Bransfield Basin and dates to $17.5 \mathrm{ka} \mathrm{BP}$ (Banfield \& Anderson, 2013). A phase of significant glacier retreat occurred in Maxwell Bay, King George Island (Figure 2C), between 14 and 8 ka BP based on ${ }^{14} \mathrm{C}$ dating of marine sediments (Milliken et al., 2009; Simms et al., 2011) and terrestrial evidence from surface exposure dating and the onset of lacustrine sedimentation (Seong et al., 2009; Watcham et al., 2011). Grounded ice receded from the Firth of Tay near Joinville Island at $\sim 9.4 \mathrm{ka}$ BP (Michalchuk et al., 2009). The presently ice-free areas of Byers Peninsula on Livingston Island (Figure 2C) were deglaciated progressively between 8.3 and $1.8 \mathrm{ka}$ BP (Toro et al., 2013; Oliva et al., 2016), with small glacier centers distributed across the area during the mid-Holocene (Mink et al., 2014). However, there is evidence that some hills such as Cerro Negro had their uppermost parts exposed above the glacial ice, functioning as nunataks during most of the Holocene (Ruiz-Fernández \& Oliva, 2016). As in Byers Peninsula, it is likely that the deglaciation of the nearby small ice-free area of Elephant Point occurred throughout the Holocene (Oliva \& Ruiz-Fernández, 2017). According to Hall \& Perry (2004), the existence of ice rafted detritus on different levels of raised beaches of Livingston Island, suggests that these sediments, even coming from the Antarctic Peninsula, could have been transported within icebergs as deglaciation progressed during the late Holocene. Similarly, on Signy Island $\left(60^{\circ} \mathrm{S}\right)$, at the extreme north of the region, the onset of deglaciation has been estimated at $\sim 7 \mathrm{ka} \mathrm{BP}$ (Jones et al., 2000).

Holocene climatic and glacial fluctuations are once again complex in the northern AP and reflect numerous driving factors, including latitudinal shifts of the westerlies, and alternating inflows of warm Circumpolar Deep Water and cold waters of Weddell Sea origin (Bentley et al., 2009). Warm and humid conditions peaked around $\sim 3 \mathrm{ka} \mathrm{BP}$ on Livingston Island, followed by (poorly constrained) Neoglacial cooling and the LIA (Björck et al., 1991; Yoo et al., 2009; Monien et al., 2011). In the last 80 years, glacier retreat in the South Shetland Islands has been driven by pronounced atmospheric and possibly also oceanic warming (Yoo et al., 2009; Monien et al., 2011; Rückamp et al., 2011), although not as rapidly as in the western and eastern sectors of the AP (Davies et al., 2012a; Cook et al., 2016).

\section{Methods}

We performed a comprehensive synthesis of the scientific literature focusing on the paraglacial dynamics in the AP region. Until now, studies have focused on single elements of different terrestrial 
systems (i.e. glacier mass balances, geomorphic processes, coastal dynamics, permafrost, plant distribution and wildlife colonization) and discrete time periods. Here, we use a multidisciplinary approach combining both geomorphological and ecological perspectives to better understand landscape changes in deglaciating AP environments.

The available data have been compiled in four tables concerned with redefinition of coastlines, past and recent permafrost and periglacial processes, alluvial and lacustrine dynamics, and geoecological responses related to paraglacial dynamics in the AP region. We differentiate past and recent processes in each of the four tables. Given that numerous climatic studies have identified the 1950s as the onset of an accelerated warming trend in the AP region as recorded at several stations across the region (Vaughan et al., 2003; Turner et al., 2005, 2016; Oliva et al., 2017a), we use the 1950s as delineating the period of recent paraglacial adjustment to glacial retreat in response to recent warming. Past processes include environmental dynamics between the LGM and the 1950s, whereas recent processes include paraglacial dynamics from 1950s to the present day.

In order to better illustrate the geographical variability of the observed changes, three different regions have been considered in this study: the eastern AP, the western AP and the northern AP and surrounding areas. Each table includes the observed geomorphological and environmental evidence, the specific areas from where paraglacial observations were made as well as the scientific references.

\section{Results}

Present-day landscape dynamics in the AP region are a consequence of long- and short-term changes in terrestrial and marine ecosystems driven by climate variability that have had large implications for the cryosphere.

\subsection{Past paraglacial dynamics: from the LGM to the first half of the $20^{\text {th }}$ century}

Long-term glacial retreat in the AP region has led to substantial geomorphological and geoecological changes across this landmass, including changes to coastlines as a result of glacio-isostatic uplift, periglacial processes and mass movements, and alluvial and lacustrine dynamics, among others. Here we present an overview of these processes subdivided into the three study regions.

\subsubsection{Coastline adjustment}

\section{The eastern AP region}

The partial deglaciation of the James Ross Archipelago during the early Holocene (Johnson et al., 2011; Glasser et al., 2014; Nývlt et al., 2014) led to glacio-isostatic uplift of individual islands and the emergence of coastal areas. Roberts et al. (2011) presented a relative sea-level curve based on lacustrine records from shallow coastal lakes from Beak Island in the northern Prince Gustav Channel, which clearly shows a slightly decelerating trend of glacio-isostatic uplift of Beak Island since the early Holocene maximum stand at $\sim 8 \mathrm{ka} \mathrm{BP}$. The early Holocene marine limit is $\sim 15 \mathrm{~m}$ a.s.l. on Beak Island (Roberts et al., 2011), whereas the highest Holocene marine terraces on the northern Ulu Peninsula (James Ross Island; Figure 2D) lie at $\sim 30 \mathrm{~m}$ (Hjort et al., 1997; Table 1). Holocene marine terraces, raised beaches and associated deposits of Ulu Peninsula were mapped by Davies et al. (2013) and Mlčoch et al. (2018). They cluster in three principal altitude levels on James Ross Island: 20-30 m, 10$17 \mathrm{~m}$ and 2-6 m (Ingólfssson et al., 1992; Strelin \& Malagnino, 1992; Hjort et al., 1997), with the largest areas of marine terraces located in Abernethy Flats and Santa Marta Slopes on the northern Ulu Peninsula (Davies et al., 2013). Isolated sand and gravel spits and modern beaches with lagging boulders are well-developed along the flat coast of northern James Ross Island (Davies et al., 2013) (Figure 3A) indicating decelerated glacio-isostatic uplift in recent times. 
Table 1

\section{The western AP region}

In the western AP, deglaciation also led to glacio-isostatic uplift of individual islands and emergence of coastal areas (Figure 3B). The highest raised beaches, formed sometime after $9 \mathrm{ka} \mathrm{BP}$, reach $40 \mathrm{~m}$ a.s.l. at Pourquoi-Pas Island and Calmette Bay (Hodgson et al., 2013), with at least 5 levels of more recent raised beaches formed between 22 and $4.5 \mathrm{~m}$ a.s.l. (Bentley et al., 2009; Guglielmin et al., 2012; Table 1). Uplift rates between 7.4 and $2.7 \mathrm{ka} \mathrm{BP}$ were suggested to have ranged between $2.7 \mathrm{~mm} \mathrm{yr}^{-1}$ (Hodgson et al., 2013) and $4.1 \mathrm{~mm} \mathrm{yr}^{-1}$ (Guglielmin et al., 2012). Differences in clast roundness between raised beaches suggest different phases of wave activity resulting from variations in summer sea ice cover. Periods with enhanced wave activity due to reduced sea ice occurred after $8.9 \mathrm{ka} \mathrm{BP}$ at Calmette Bay, between 6 and $2.3 \mathrm{ka} \mathrm{BP}$ at Horseshoe Island (Hodgson et al., 2013) and between 3.5 and $2.4 \mathrm{ka}$ BP at Rothera and Anchorage Island (Bentley et al., 2005a; Guglielmin et al., 2012). Relative sea level was also inferred from elevated lake deltas on Alexander Island, with the last period of intensive delta formation occurring in the mid-Holocene (ca. 4.5 ka BP; Roberts et al., 2009).

\section{The northern AP region and surrounding areas}

Warmer conditions during the late Pleistocene-early Holocene (especially between 15-14 ka BP and 6 ka BP; Ingólfsson et al., 2003; Milliken et al., 2009; Seong et al., 2009; Watcham et al., 2011; Weber et al., 2014), caused significant ice loss and glacial retreat in the northern AP and adjacent islands. The highest raised beaches in the region have been dated to between 7.5 to 7 ka BP (Hall, 2010; Watcham et al., 2011). Glacio-isostatic rebound models created for the South Shetland Islands show a center of maximum uplift between Greenwich and Robert islands (18.7 to $20.4 \mathrm{~m}$ ), with rebound rates between 2.2 and $4.8 \mathrm{~mm} \mathrm{yr}^{-1}$ over the last $7 \mathrm{ka} \mathrm{BP}$ (Fretwell et al., 2010; Watcham et al., 2011; Table 1). New coastal areas emerged due to this uplift (John \& Sudgen, 1971; Bentley et al., 2005a; Fretwell et al., 2010; Hall, 2010; Watcham et al., 2011), with the development of 5-7 levels of raised beach levels through the mid- and late Holocene at elevations between 2 and $20 \mathrm{~m}$ (Fretwell et al., 2010; Hall, 2010; Simms et al., 2012; Figure 3C).

\subsubsection{Permafrost, periglacial processes and mass movements The eastern AP region}

Rock glaciers are common in ice-free landscapes of the eastern AP (Strelin et al., 2007; Fukui et al., 2008; Davies et al., 2013; Guglielmin et al., 2018). They mostly originate from ice-cored moraines that began creeping (i.e. they represent glacier-derived rock glaciers sensu Humlum, 1996). Exposures of glacier ice are often visible in central parts or in marginal talus (Strelin \& Sone, 1998). Less common are talus-derived rock glaciers (Figure 4A), which generally originate from vast accumulations of debris scree at the foot of volcanic mesas with buried snow deriving in interstitial ice (Davies et al., 2013). Large-scale mass movements are characteristic on the slopes of volcanic mesas of the James Ross Archipelago, where rock blocks detaching from the original surface of the deltaic topsets slide downslope, fall or topple and create chaotic accumulations of blocks beneath the cliffs (Davies et al., 2013). These steep slopes are prone to mass wasting and accumulation of material forming talus cones or scree slopes, and protalus ramparts are a common landform observed in the scree accumulations (Table 2) (Ermolin et al., 2002; Davies et al., 2013; Nozal et al., 2013; Mlčoch et al., 2018). The age of these landforms is unknown, although the mass movement processes have likely operated throughout the Holocene (Davies et al., 2013; Smellie et al., 2013).

Figure 4 
Table 2

\section{The western AP region}

The western AP is much more glacierized than the eastern AP, and terrestrial environments and ice-free areas are therefore spatially limited (Figure 4B). Data on permafrost distribution and thermal state are scarce (Bockheim et al., 2013; Guglielmin et al., 2014). Sporadic permafrost has been detected in the Palmer Archipelago and the Biscoe Islands at elevations above 100-180 m (Bockheim et al., 2013) with active layer thicknesses exceeding $10 \mathrm{~m}$ on bedrock (Wilhelm et al, 2016), whereas at Rothera $\left(67^{\circ} 57^{\prime} \mathrm{S}\right)$ permafrost is continuous with soil temperatures of $-3^{\circ} \mathrm{C}$ (Guglielmin et al., 2014). Permafrost in the western AP is strongly controlled by snow accumulation and therefore its characteristics are highly localized (Guglielmin et al., 2014). Geomorphic indicators of permafrost conditions present in other maritime polar environments (e.g. rock glaciers, pingos, ice wedge polygons, active layer detachment failures) are absent in the western AP region. Stone-banked solifluction lobes and terracettes are quite common, although they may form under a seasonal frost regime (Table 2).

\section{The northern AP region and surrounding areas}

Glacial retreat at the northern tip of the AP favored very intense periglacial processes. The humid conditions in the area, with common rain and snow events and frequent freeze-thaw cycles during summer (Oliva et al., 2017b), enhance physical weathering and promoted the development of periglacial landforms immediately after deglaciation. Under these conditions, processes such as solifluction, cryoturbation and mass movement are very active and lead to the formation of a wide range of periglacial phenomena between sea level and ca. $300 \mathrm{~m}$ (Table 2).

Despite the lack of absolute ages from periglacial landforms, there are at least two stages of periglacial activity in areas of the South Shetland Islands, such as Byers Peninsula, based on morphostratigraphic criteria and dating of other deposits and landforms (Ruiz-Fernández \& Oliva, 2016). During the first stage, when glacial ice still covered most of the present-day ice-free areas, the periglacial landforms (e.g. block streams) that developed under very intense cold conditions were spatially restricted to the limited ice-free areas of the nunataks and some coastal fringes. Subsequently, a second periglacial phase occurred as glacial retreat accelerated, resulting in a wide range and distribution of periglacial landforms (e.g. solifluction, patterned ground features) formed under a climate regime that was less severe than the previous stage (Ruiz-Fernández \& Oliva, 2016). Whereas the first landforms are indicative of permafrost conditions, the latter do not strictly imply permanently frozen conditions but may be also related to seasonal frost (Table 2).

The landforms formed following deglaciation include rock glaciers, protalus lobes and block streams, which are permafrost-related features present in ice-free environments of the northern AP region (Table 2). The presence of these landforms reveals the existence of permafrost conditions, in some cases down to sea level (Araya \& Hervé, 1972; Serrano \& López-Martínez, 2000; Serrano et al., 2004; LópezMartínez et al., 2012). In the South Shetland Islands Serrano \& López-Martínez (2000) identified nine rock glaciers and eleven protalus lobes formed during three stages: after the last major deglaciation, between $2 \mathrm{ka} \mathrm{BP}$ and pre-LIA, and during the LIA (Table 2). Glacial retreat has generated glacierderived rock glaciers in some cases (38\% of the total). However, talus-derived rock glaciers are dominant in the South Shetland Islands (62\%; Serrano \& López-Martínez, 2000). Block streams are landforms inherited from colder stages in some sectors (Ruiz-Fernández \& Oliva, 2016), while in others they are fully active (López-Martínez et al., 2012). In the Hope Bay area (Figure 2D), under colder conditions, talus cones and patterned ground features were generated following deglaciation in the successively created ice-free areas (Birkenmajer, 1988; Schaefer et al., 2015). 
The ice-free areas formed throughout the Holocene are largely covered by sediments either deposited by glaciers, generated by physical weathering, or elevated by glacio-isostatic uplift (Fretwell et al., 2010; Hall, 2010; Watcham et al., 2011; López-Martínez et al., 2012; Oliva et al., 2016). These environments, rich in fine particles, are favorable for the development of intense cryoturbation processes (Table 2). A wide range of patterned ground features is thus distributed across level surfaces and gentle slopes (e.g. stone fields, stone sorted-circles, stone stripes, stone polygons, micropolygons, earth hummocks and mudboils; Guglielmin et al., 2008; López-Martínez et al., 2012; Figure 4C). Solifluction landforms are abundant on gentle slopes covered by detrital deposits, whereas talus cones are common landforms at the foot of rock walls, volcanic plugs, rocky outcrops and scarps (LópezMartínez et al., 2012; Oliva \& Ruiz-Fernández, 2017).

\subsubsection{Alluvial and lacustrine dynamics \\ The eastern AP region}

Numerous lakes formed in the area of the James Ross Archipelago in connection with deglaciation (Björk et al., 1996; Hjort et al., 1997; Sterken et al., 2012; Nedbalová et al., 2013). The oldest lakes are those located on higher-lying uplifted marine terraces, on old levelled surfaces shaped by glacier erosion or in old moraines (Table 4). For coastal lakes on marine terraces, the transition from shallow marine to lacustrine environments was reconstructed from sedimentary records and/or biostratigraphy (Ingólfsson et al., 1992; Hjort et al., 1997; Sterken et al., 2012). A large number of stable lakes appear on the volcanic mesas of both James Ross and Vega islands (Table 3). Lakes in old moraines (Nedbalová et al., 2013) were formed either during the Pleistocene-Holocene transition, or more commonly after local glaciers retreated following Neoglacial advances (Table 3). Late Holocene glacial advances connected with the local LIA (Carrivick et al., 2012) led to the formation of prominent morainic ridges surrounding local glaciers, which underwent rapid retreat especially in the last several decades (Davies et al., 2012; Engel et al., 2012). Glacier retreat and down-wasting are connected with formation of cirque lakes on northern James Ross Island that are rather stable and perennially icecovered (Nedbalová et al., 2013).

Deglaciation also led to the formation of the modern fluvial network, which either followed the deglaciation pattern (Figure 5A), or the pattern predisposed by geological the structure (e.g.; Kavan et al., 2017). Sediment load in streams of the James Ross Archipelago is mostly suspended load originating from underlying strata or transported by wind action (Kavan et al., 2017; Kavan \& Nývlt, 2018). Beddominant load is typical for proglacial streams, where coarse-grained material is available depending on geological conditions.

Figure 5

Table 3

\section{The western AP region}

Fewer lakes occur in the ice-free areas of the western AP with respect to the eastern AP but especially in Marguerite Bay. Some have been studied in detail, and the evolution of these lacustrine environments and the chronology of glacial retreat is thus quite well understood. In Narrows Lake, located on the NE ice-free coast of Pourquoi-Pas Island, an increase in productivity was recorded between 9.3 and $8.5 \mathrm{ka}$ $\mathrm{BP}$, indicating a warm period coincident with glacial retreat and warm, open ocean conditions between $\sim 9$ and 7 ka BP (Hodgson et al., 2013).

\section{The northern AP region and surrounding areas}

Holocene glacial retreat favored the progressive appearance of numerous lakes and coastal lagoons in newly exposed ice-free areas (Figure 5C). In several ice-free areas of the South Shetland Islands there 
are dozens of lakes distributed in overdeepened glacial basins and dammed by moraines that began to form during the early Holocene, whereas others located closer to present-day glacier fronts have appeared during the last millennium, as reported for Fildes (Watcham et al., 2010), Barton and Byers peninsulas (Oliva et al., 2016). Dating of the basal sediments provided information about the age of lake formation and thus the pattern and timing of glacial retreat, and showed evidence of augmented mineral sediment inputs during the paraglacial stage. For example, in the largest ice-free area of the South Shetland Islands, Byers Peninsula, lakes appeared across the peninsula between $8.3 \mathrm{ka}$ BP and $1.8 \mathrm{ka}$ BP, with ages related to distance from the glacier front (Toro et al., 2013; Oliva et al., 2016). Lakes formed at relatively high elevations near glacial domes and alpine glaciers, as well as in lowaltitude environments near sea level, with some of them being uplifted due to glacio-isostatic rebound. Poor drainage favored water retention and the development of (semi-permanent) lakes behind the different levels of the relatively flat marine platforms and raised beaches. In some cases, these coastal lagoons are directly related to ice retreat near the glacial fronts, and were therefore formed during the paraglacial stage, whereas others formed when the uplift isolated coastal basins which then became infilled with freshwater (Watcham et al., 2010). This process has been reported in several other ice-free environments in the northern AP region (Table 3). For Signy Island, multiproxy data provided evidence of remarkable Holocene climatic changes driving significant environmental changes (e.g. Jones et al., 2000; Hodgson \& Convey, 2005), though there is no reference to paraglacial dynamics in those studies.

Paraglacial dynamics also condition the drainage systems in areas underlain by permafrost. This is particularly evident in relatively flat and gently sloping environments, such as the Byers Peninsula, where the shape of drainage basins and a limited hierarchical network reveals a youthful stage of landscape evolution (Mink et al., 2012). Such poorly developed drainage networks are common in many other ice-free landscapes of the northern AP region.

\subsubsection{Geoecological response to paraglacial adjustments}

Deglaciation created new areas for soil development as well as plant and wildlife colonization. The oldest ice-free landscapes have better developed soils in contrast to recently deglaciated environments, as weakening paraglacial processes allowed for earlier soil formation (González-Guzmán et al., 2017; Navas et al., 2017). Soil development was enhanced by the attenuation of cryoturbation and other sediment remobilization processes, resulting in the formation of cryogenic soils (mostly abiotic soils). Plant colonization of deglaciated areas typically occurred through directional succession, with increasing species diversity and plant cover over time and concomitant changes in species composition: pioneer mosses and lichens occurred on recently exposed landscapes, then disappeared completely in early and late successional stages when they were replaced by other species that, once established, were able to persist to the oldest successional stages (Favero-Longo et al., 2012).

Soil development in ice-free landscapes of the AP has been influenced by biological activity, generally due to the effects of pinniped and sea bird populations. These communities may enhance soil acidification and increase the concentration of certain soil chemical compounds as well as organic matter content (Blume et al., 2002; Simas et al., 2007; Strauss et al., 2009; Moura et al., 2012). Dense concentrations of animals also result in high nutrient inputs in ice-free areas due to the deposition of excrement and the resulting fertilization of terrestrial ecosystems. Vertebrate colonies may thus play an important role in determining the distribution and abundance of vegetation in the AP region (Tatur, 2002; Smykla et al., 2006; Michel et al., 2006; Ruiz-Fernández et al., 2017). In general terms, wildlife occurrences increase with distance from glaciers and are merely sporadic in the young deglaciated foreland. Ornithogenic soils have been observed to develop during the last $6 \mathrm{ka} \mathrm{BP}$ in parallel with the occupation history of sea birds, with progressively older occupations from the northern to southern AP despite the fact that previous records of penguin occupation in the northern AP may have been erased 
by LIA glacial readvances (Emslie, 2001; Table 4). Ornithogenic soils in the Hope Bay area occupy late Pleistocene to Holocene moraines, marine terraces and rocky outcrops, usually at low altitudes $(<60$ m) (Pereira et al., 2013; Schaefer et al., 2015).

Several cycles of glacier advance and retreat that induced vegetation responses can be identified and reconstructed through the analysis of moss peat banks and peat deposits. Moss peat banks are a characteristic and unique feature of Antarctic vegetation occurring in the northern and western AP as far as $\sim 69^{\circ} \mathrm{S}$. These features differ from peat deposits, as they develop through the combination of the low temperature and $\mathrm{pH}(3.5-4.5)$ of the peat (inhibiting microbial activity) and the occurrence of permafrost (Fenton \& Smith 1982; Cannone et al., 2017a) and not in depressions associated with water saturation and anaerobiosis. These features permit the inference that permafrost aggradation occurred after glacial recession in several locations, as moss peat banks develop only under favorable climatic conditions characterized by cool and wet summers (Royles et al., 2012), and their conservation requires the persistence of permafrost that prevents the degradation of the organic matter (Fenton 1982; Cannone et al., 2017a).

\section{The eastern AP region}

Biological activity in the eastern AP region is limited due to the very low precipitation, which is a critical factor for plant colonization and vegetation development (Elster, 2008; Láska et al., 2011; Figure 6A). Soils in the eastern AP are generally poorly developed with low organic content (Souza et al., 2014). However, in the James Ross Archipelago, hundreds of seal carcasses were found to have played an important role in promoting vegetation colonization (e.g. Nelson et al., 2008; Negrete et al., 2011, 2015; Nývlt et al., 2016). These carcasses represent important vectors of nutrients (Nývlt et al., 2016), but also of contaminants (Zvěřina et al., 2017), from the marine environment to nutrient-poor, ice-free environments where they produce hotspots of nutrient rich soil that are commonly colonized by mosses, lichens and algae (Nývlt et al., 2016).

Figure 6

Table 4

\section{The western AP region}

Plant colonization in the western AP has been observed to have followed a directional succession (Corner \& Smith, 1973; Smith, 1982; Table 4 \& Figure 6B). In this region, moss peat banks developed due to permafrost aggradation in a paraglacial context, but developed later than in the northern AP (after $630 \pm 50 \mathrm{yr}$ BP, Smith 1982) with the youngest ages recorded in the southwestern AP (AD 1860, Royes et al., 2013). On the other hand, in several areas of the western AP, penguin occupation cycles during the Holocene correlate with glacial advances and retreats, with increased occupation identified between 4 and 3 ka BP (Emslie \& McDaniel, 2002; Table 4). Following deglaciation, the resulting postglacial rebound promoted a gradual redistribution of penguin colonies that moved onto newly exposed ground and left behind the former rookeries where ornithogenic cryosols had started forming (Emslie et al., 1998; Table 4).

\section{The northern AP region and surrounding areas}

In regions where local-scale environmental characteristics are less severe, such as the northern AP region, landscape age is often the main driver of plant colonization, as observed in undisturbed regions of the northern AP where landscapes deglaciated from the LGM to the LIA to the $20^{\text {th }}$ century (FaveroLongo et al., 2012). The time needed for colonization in the northern AP region ranged between several 
decades for the earliest colonization by pioneer species to three or four hundred years for the establishment of immature communities, while the climax stage can develop only in the oldest ice-free landscapes (e.g., Polytrichum strictum-Chorisodontium aciphyllum community at Signy Island, FaveroLongo et al., 2012; Table 4, Figure 6C). Similar patterns have been reported from several localities in the northern AP (Sancho \& Valladares 1993; Smith 1995; Sancho \& Pintado 2004, Table 4). However, disturbance factors, such as those associated with coastal dynamics, may alter this pattern, with the richest vegetation and highest coverage having been observed on coastal surfaces of intermediate deglaciation age, rather than the oldest landscapes where vegetation was less developed (Kozeretska et al., 2010). The oldest moss peat banks in the northern AP were dated at 5.5 ka BP (Fenton, 1982; Bjorck et al., 1991), while peat deposits provided a slightly younger age (Ye \& Rongquan 1999). Ornithogenic soils were also described near penguin colonies in Hope Bay (e.g. Pereira et al., 2013) and on Seymour Island (Souza et al., 2014). Chemical and mechanical weathering caused the alteration of guano layer and underlying phosphatized rock into ornithogenic soils, which are now at some places considered relict (Tatur, 1989).

\subsection{Recent paraglacial dynamics since the $1950 \mathrm{~s}$}

The warming that has occurred since the 1950s in the AP and surrounding areas has led to intense paraglacial processes in the new ice-free landscapes that have been generated during the last several decades. These processes are triggering significant changes in the terrestrial ecosystems of these areas.

\subsubsection{Coastline adjustment The eastern AP region}

Recent coastline changes in the eastern AP region are related to ice shelf disintegration (Prince Gustav and Larsen A ice shelves in 1995; Larsen B ice shelf in 2002), which exposed new coastal areas (Skvarca et al., 1995; Cook \& Vaughan, 2010; Davies et al., 2012a). These changes were most pronounced in the areas of the James Ross Archipelago and the Nordenskjöld and Oscar coasts of the eastern AP. At present, ice unloading is driving glacioisostatic uplift in the sector of the Robertson Trough of up to $\sim 40 \mathrm{~mm}$ yr-1 (Nield et al., 2014). Recent beaches are well-developed along the coast of the Ulu Peninsula (James Ross Island), with sand and gravel spits enclosing small bays due to sediment redistribution by coastal currents (Davies et al., 2013; Table 1, Figure 3D).

\section{The western AP region}

Coastline changes in the western AP region are also linked to changes in glacier extent that are less obvious and homogeneous in this sector (Figure 3E). According Seehaus et al. (2018), since 1985 numerous glaciers along the west coast of the AP show stable ice-front positions or even some advance. Locally, pronounced retreats have also been recorded, such as at Rothera Station (Guglielmin et al., 2016), but they did not affect the coastline.

\section{The northern AP region and surrounding areas}

Paraglacial dynamics in response to the enhancement of glacial retreat due to recent warming is also affecting contemporary coastal processes, as shown by the formation of tombolos and present-day beaches (Figure 3F). Well-developed and incipient tombolos in tidal environments are common landforms in coastal areas of the northern AP region near glacier fronts and moraine systems that favor high sedimentary inputs (e.g. Elephant Point on Livingston Island; Oliva \& Ruiz-Fernández, 2017). By contrast, present-day beaches are forming on the lowest levels of Holocene raised beaches and at the foot of glacier fronts located on coastal edges. Recent glacial retreat in some areas has also favored the development of new proglacial environments during recent decades due to the very high sediment discharge remobilized by proglacial streams towards the sea (Table 1). Subsequently, these sediments are redistributed along the shorelines by coastal processes. 


\subsubsection{Permafrost, periglacial processes and mass movements The eastern AP region}

Recent paraglacial processes in the eastern AP region are limited in their extent due to slower retreat of local glaciers (Figure 4D). The recent areal changes of land-terminating glaciers were on the order of tens of square meters per year (e.g.; Skvarca et al., 1995; Engel et al., 2012). The newly formed ice-free areas with possible paraglacial response have thus not been of the scope for periglacial research as of yet. Scree formation on foothills of volcanic mesas is the dominant modern process on ice-free surfaces (Davies et al., 2013). Frost shattering is widespread on the surfaces of volcanic mesas including basalt boulder subvertical turning due to freeze-thaw processes (Davies et al., 2013). In places, protalus ramparts show clear activity connected with material translation through the clast rolling down the seasonal snow banks.

\section{The western AP region}

Thermal weathering and thermal shock (Hall, 1997) are very active in newly exposed areas, even in granitic outcrops such as on Alexander Island, as well as frost shattering in metamorphic or sedimentary areas (Figure 4E). The widespread distribution of permafrost conditions that show evidence of degradation (at least until 2012; Bockheim et al., 2013) favor landslides, rockfalls and debris flows, although no visible exposure of ice-rich frozen sediments has been detected (Table 2).

\section{The northern AP region and surrounding areas}

Paraglacial processes in this region, in the form of very active periglacial activity, are very intense in non-consolidated sediments following glacial retreat (Table 2). Frost shattering is very active in this area, affected by high moisture and a high number of freeze-thaw cycles (Oliva et al., 2017b), mainly on sedimentary and metamorphic rocks. In gentle to moderate slopes, the resulting debris can be subsequently mobilized downslope by solifluction dynamics or even by rapid mass wasting processes such as mudflows, debris flows and landslides (Oliva \& Ruiz-Fernández, 2017; Figure 4F). This sediment transfer between proglacial environments, slopes and valley bottoms can be enhanced by the presence of permafrost (López-Martínez et al., 2012; Oliva \& Ruiz-Fernández, 2015). In some recently deglaciated environments, slope processes can expose permafrost, which has been found as warm/cold and ice-rich/dry, depending on the location and the thermal character of the glacier bases (Oliva \& RuizFernández, 2015). In some permafrost areas, frost mounds formed by ice segregation have been identified (López-Martínez et al., 2012; Oliva \& Ruiz-Fernández, 2017).

Rockfall activity is also very high in recently deglaciated vertical walls, favoring the development of scree deposits at the foot of the cliffs. Patterned ground features are very abundant in relatively flat areas (favored by the existence of fine sediments), especially stone stripes, stone sorted-circles and stone fields (Table 2).

\subsubsection{Alluvial and lacustrine dynamics}

Recent glacial retreat has led to the formation of new proglacial areas where alluvial processes are changing the landscape and new lakes are appearing.

\section{The eastern AP region}

Seasonal braided streams drain the proglacial environments between glacier fronts and moraines or the sea, in some cases even forming alluvial fans (Table 3). Ice-cored moraine degradation leads to the formation of kettle/perched lakes (Carrivick et al., 2012; Davies et al., 2013; Nedbalová et al., 2013), which are the least stable of all lake types found in the James Ross Archipelago. Sone et al. (2007) reported on the outburst of such a lake from the eastern flank of Lachman Crags (James Ross Island) 
between 2004 and 2005. Glacial lakes have also formed near glacier fronts (Nedbalová et al., 2013; Figure 5D).

\section{The northern AP region and surrounding areas}

In addition to lakes formed near glacier fronts (Toro et al., 2007, 2013; Oliva et al., 2016), in recently deglaciated environments of the northern AP region there are abundant coastal lagoons (e.g. coastal lagoon near Clark Nunatak in Byers Peninsula, Figure 5F). Local fluvial activity is restricted to a few months in summer (Mink et al., 2012; Kavan et al., 2017), when the streams are mostly fed by meltwater from glaciers, snowfields, or permafrost.

\subsubsection{Recent geoecological response}

Recently, a greening trend has been observed in Antarctica that has been attributed to warming (Amesbury et al., 2017). However, in the recently exposed ice-free areas of the AP region where paraglacial responses are very intense, several other processes have been detected. Deglaciation has resulted in an increase in ice-free areas with ground exposed to low temperatures and freeze-thaw cycles, which have proven to be a key factor in soil weathering in the AP region (Blume et al., 2002; Navas et al., 2006, 2008; Strauss et al., 2009; Moura et al., 2012; Michel et al., 2014). In these environments, intense cryoturbation with continuous sediment redistribution favors highly unstable soils, thus preventing plant colonization (Oliva et al., 2015; Ruiz-Fernández et al., 2016, 2017). In many deglaciated areas, not enough time has passed to diminish the activity of geomorphic processes and stabilize sediment redistribution, thus permitting soil development and plant and wildlife colonization. The amount of time elapsed since deglaciation is therefore a key factor explaining soil evolution and vegetation colonization in ice-free areas of the AP region (Simas et al., 2007; Strauss et al., 2009; RuizFernández et al., 2017).

Soils in recently deglaciated areas are typically coarse-textured and poorly developed. Cryosoils with low organic matter content are widespread due to the limited microbial contribution to soil development in cold temperature regimes (Blume et al., 2002). Consequently, in these environments organic matter levels were lower compared to guano- or vegetation-enriched soils in older environments (Engelen et al., 2008; González-Guzmán et al., 2017; Navas et al., 2017). The transport of mineral and organic matter is important in the process of biological colonization of newly exposed terrain. Water and wind, but also wildlife, have proven to be effective transport agents for both flora and microfauna (Janiec, 1996; Smykla et al., 2006; Schlensog et al., 2013).

The question of whether the very first colonizers of glacier forefields after glacier recession were microbial communities or plants is still under debate, even if soil microbial community can be detected just one year after deglaciation (Strauss et al., 2012). The activity of heterotrophic microbes (both bacteria and fungi), autotrophic microbes and nitrogen-fixing diazotrophs has been hypothesized to be the agent of the initial build-up of labile nutrient pools, although it still remains unclear to what extent microbial life or external sources are responsible for initial nutrient concentrations (Bradley et al., 2014). Indeed, in many cases, nitrogen-fixing cyanobacteria are the photobiont (or photosynthetic partner in lichen symbiosis) of pioneer lichen species colonizing glacier forefields. Their nutrient fixation and subsequent degradation ensures the nutrient enrichment of recently deglaciated bare ground and promotion of further colonization by other plant species.

\section{The eastern AP region}

Periglacial processes limit the development of vegetation in newly ice-free areas exposed by recent glacial retreat (Cannone \& Guglielmin, 2008; Figure 6D). However, no dispersal limitation for the lichen colonization of newly deglaciated substrates of volcanic mesas was found on James Ross Island, but lichen establishment is rather rare and growth of lichen communities is therefore a long-term process 
(Bohuslavová et al., 2018). Nutrients are effectively released from decaying seal carcasses, of which hundreds were mapped in ice-free areas of the James Ross Archipelago (e.g. Nelson et al., 2008; Negrete et al., 2015; Nývlt et al., 2016). According to radiocarbon ages most died during the last century, although a number of new carcasses appear every spring on Ulu Peninsula, James Ross Island (Nývlt et al., 2016). Recent mapping (Nedbalová et al., 2017) revealed that the fairy shrimp Branchinecta gaini, the largest Antarctic freshwater invertebrate, was more widely distributed in freshwater lakes of the James Ross Archipelago relative to samples taken 20-25 years ago (Björck et al., 1996). The desiccation of shallow lakes, which can occur due to evaporation or drainage following permafrost degradation, is another important phenomenon that may drastically change the availability of freshwater habitats (Váczi et al., 2011).

\section{The western AP region}

Vegetation and soil succession show similar patterns, with mineral soils that are typically coarsetextured and poorly developed in recently deglaciated areas, and more evolved soils situated on older tundra (Strauss et al., 2009; Table 4 \& Figure 6E). However, this successional trend is not always linear due to the impacts of environmental factors, which may decrease vegetation development through disturbance, or increase it through processes mainly associated to animal occurrence (Table 4). Cryoturbation has also been identified as a major factor of environmental disturbance affecting the colonization of recently deglaciated terrains by vegetation, with very poor lichen and bryophyte flora that are restricted to rock surfaces and crevices, and to the margins of soil polygons (Engelen et al., 2008 , 2010), mainly as a result of particle size sorting processes associated to cryoturbation and solifluction (Blume et al., 2002).

\section{The northern AP region and surrounding areas}

According to the prevailing patterns of ecological succession in glacier forefields, the visible plant colonization of recently deglaciated terrains started in the first 20-30 years after glacier retreat and was typically characterized by the appearance of pioneer epilithic lichens (Sancho \& Valladares, 1993; Smith, 1995; Figure 6F), with the size and coverage of lichen increasing with age since deglaciation (Valladares \& Sancho, 1995; Table 4). Recent climate warming further increased the colonization rate of pioneer lichens and mosses on ground recently exposed by glacier recession (Convey \& Smith, 2006). On the other hand, the enrichment of terrestrial organic matter associated to animals (e.g. GonzálezGuzmán et al., 2017; Navas et al., 2017) may facilitate vegetation colonization. On Signy Island, the rate and extent of lichen colonization 20 years after deglaciation varied depending on nutrient availability, with epilithic lichens covering between 40 and $>90 \%$ in nutrient-enriched sites, but only of 20-25\% in non-biotically-influenced sites (Smith, 1995).

\section{Discussion}

Our analyses of the distribution of landforms and processes associated with paraglacial activity in three contrasting climatic regions of the AP demonstrates that there are clear regional differences in the magnitude and type of response (Figure 7).

\section{Figure 7}

\subsection{Factors and processes controlling paraglacial responses in the AP region}

The time elapsed since deglaciation is the crucial factor controlling the intensity of paraglacial processes (Ballantyne, 2002). The configuration of the same AP region is, in part, a consequence of the paraglacial response that occurred at long-term scales. Glacial retreat since the LGM has reshaped coastlines, favoring the emergence of new islands and peninsulas as well as exposing new fjords and bays (Ó Cofaigh et al., 2014). Short-term paraglacial dynamics have also changed landscapes at the local scale, 
favoring the development of periglacial landforms and sediment redistribution through a wide range of processes.

Time elapsed also constrains the availability of sediment for mobilization. Environments where several centuries to millennia have passed since the paraglacial stage host soils that contribute to stabilize the sediments, even with an incipient vegetation cover, as in the uppermost raised beaches and bedrock plateaus of Elephant Point, Livingston Island (González-Guzmán et al., 2017). In some of these areas, biological activity can also contribute to soil fertilization (Blume et al., 2002; Simas et al., 2007; Strauss et al., 2009). However, recent studies in the northern AP region show that soil development in deglaciated environments is highly influenced by other factors (e.g. geology, altitude, slope, weathering intensity, sediment sources) (Navas et al., 2018). Therefore, soil development under paraglacial conditions can be very spatially variable, reinforcing the idea that the evolution of these landscapes is non-uniform (Oliva et al., 2019). By contrast, mass wasting is still highly prevalent in recently deglaciated (i.e., the second half of the $20^{\text {th }}$ century) areas, with very active geomorphic processes favoring continuous sediment remobilization and impeding well-developed soils that favor vegetation cover (Oliva \& Ruiz-Fernández, 2015; Ruiz-Fernández et al., 2017).

Cryptobiosis, a state in which an organism ceases all metabolic processes in order to survive periods of intense adverse conditions, may also be linked with paraglacial dynamics. Entire moss patches survived six centuries of cold-based glacier burial through cryptobiosis, and were able to return to a metabolically active state after re-exposure due to glacier retreat (Cannone et al., 2017b). This finding provides new perspectives concerning species survival during glaciations and mechanisms of potential recolonization during the paraglacial stage. On the other hand, during the Holocene paraglacial phase a particular ecological response occurred in the northern AP, and later in the western AP, with the formation of moss peat banks where permafrost occurred (Cannone et al., 2017a).

Another critical factor controlling the intensity of paraglacial processes is the local climate. Physical weathering is more active in the western AP, and particularly in the northern AP, where summer temperatures favor freeze-thaw cycles, frost shattering and cryoturbation (Balks et al., 2013). The cool and wet summers, along with rain events and positive temperatures, favor snow melt and surface runoff, as well as a thickening of the active layer and permafrost degradation, which in turn enhance periglacial dynamics (López-Martínez at al., 2012; Oliva \& Ruiz-Fernández, 2017). In the Hope Bay area, colder conditions relative to the South Shetland Islands produce shallow permafrost depths, intense frost shattering and the suppression of soil development processes (Schaefer et al., 2015). In the drier and colder eastern AP, the lower soil moisture conditions limit periglacial activity in recently deglaciated environments.

The transition from glacial to periglacial conditions is also strongly affected by the typology of glaciers. While the retreat of warm-based glaciers does not condition the presence of permafrost following deglaciation - even if climatic conditions favor its formation - cold-based glaciers determine the existence of permafrost once the land surface is exposed after glacier retreat (Carrivick et al., 2012). This is the case of the eastern AP, where dryer permafrost relative to the northern or western AP (Hrbáček et al., 2016) will condition paraglacial dynamics; in contrast, in the northern AP, such as in the South Shetland Islands, polythermal glaciers determine different patterns of response in neighboring areas. Paraglacial processes will be particularly effective in ice-rich permafrost environments, enhancing erosion and mass wasting processes (Oliva \& Ruiz-Fernández, 2015). Thermokarst erosion may affect previously stable moraines, such as in the Hope Bay area where the formation of depressions have been observed (Birkenmajer, 1988, Schaefer et al., 2015). Thermokarst processes have also been 
identified in present-day proglacial areas of the northern AP such as Elephant Point, where tens of kettle-lakes appeared during the last several decades (Oliva \& Ruiz-Fernández, 2015).

The geomorphological setting also determines the types of processes that occur, as well as sediment redistribution. Areas with widespread unconsolidated sediments, such as moraines, coastal environments or proglacial areas that become exposed after glacier retreat, favor sediment remobilization by periglacial slope processes and alluvial dynamics. Consequently, the configuration of drainage systems is also altered, increasing erosion, transport and sedimentation processes in valley bottoms and across shorelines (Oliva \& Ruiz-Fernández, 2015). Newly exposed bedrock is affected by glacial debuttressing, which favors the formation of screes at the feet of cliffs (Grämiger et al., 2017).

Gravitationally-induced mass movement processes related to former glaciation have thus far received limited attention in the AP region, or indeed in the whole Antarctic (Gordon et al., 1978; Fitzsimmons, 1996; Davies et al., 2013). Nonetheless, high availability of unconsolidated glacigenic sediments, driftmantled slopes and steep rockwalls preconditions these landsystems to be susceptible to slope relaxation and gravitational deformation, in turn leading to significant paraglacial modification (Ballantyne, 2002). Talus accumulations in the form of debris cones or aprons (scree slopes) are ubiquitous features formed beneath steep headwalls of oversteepened glacial cirques and valleys, or cliffs of vertically jointed hyaloclastite deposits (Davies et al., 2013). Following glacier retreat or ice surface lowering, debuttressing and stress release incite rockfalls or the toppling of weathered or fractured rock and its accumulation at slope foothills (Ballantyne, 2002). The importance of rockfall erosion has recently been studied in the southern AP, where long-term erosion rates due to rockfall are considered to be greater than those for cold-based ice action, thus providing ample debris supply for glacier landsystems (Dunning et al., 2016). In the Ellsworth Mountains, near the southern edge of the AP, Marrero et al. (2018) found that subaerial erosion rates are also influenced by the availability of abrasive, predominantly aeolian material, which is again related to areas with potential sediment supply. Finally, rockfall also modifies isostatically uplifted coastal cliffs in the South Shetland Islands (Strzelecki et al., 2017).

\subsection{Expected environmental evolution}

The polar regions are among the areas expected to show the most dramatic climatic changes in the forthcoming decades. International reports suggest that the average warming across the whole Antarctic continent may reach $\sim 3^{\circ} \mathrm{C}$ (IPCC, 2014), which will lead to significant environmental consequences in the AP region. Temperature increases may be associated with increasing precipitation in the western and northern AP, while decreased precipitation is predicted for the eastern AP (IPCC, 2014) Depending on the seasonality and magnitude of precipitation changes, the mass balances of glaciers may increase or decrease, though most models show glacial loss by the end of the $21^{\text {st }}$ century (Radic et al., 2014).

Among the main consequences of this warming scenario in terrestrial environments in the AP region will be an increase in the number of ice-free areas as well as the expansion of the ice-free areas that already exist. Consequently, new areas will be affected by paraglacial dynamics and therefore an accurate characterization of environmental dynamics in the areas recently affected by glacial retreat may be useful for anticipating the future responses of terrestrial ecosystems in the AP region (Oliva \& Ruiz-Fernández et al., 2015).

The processes affecting newly ice-free environments will differ depending on the lithology, geomorphological and topographical setting and local climate conditions. In the drier eastern AP region, the predominance of cold-based glaciers implies the existence of permafrost once deglaciation occurs. Consequently, if precipitation is unchanged or decreases in the eastern AP, the amount of water stored 
within the active layer will continue to be limited and therefore the activity of periglacial slope processes will not increase.

In the northern $\mathrm{AP}$, where temperatures are currently positive during the summer season, more areas with a significantly larger land surface affected by paraglacial activity are expected. Following deglaciation, the intensity of paraglacial processes in this region will depend on glacier type (cold- vs warm-based) and the existence of permafrost. The presence of ice-rich permafrost immediately after deglaciation, where sediments are still unconsolidated and physical weathering processes are very intense, will generate environments in which paraglacial processes are highly active. In these areas, mass wasting processes, the formation of patterned ground features, thermokarst processes and permafrost degradation may accelerate with higher temperatures (Oliva \& Ruiz-Fernández, 2015). In the southwestern AP, where temperatures are lower and the number and extent of deglaciated environments is also lower, the spatial distribution of paraglacial processes will be limited, showing similar processes to those of the northern and northwestern AP, but generally of lower magnitude.

There will also be some general patterns of response to glacial retreat across the AP region. Slow and gradual redefinition of coastlines, with the appearance of some lagoons, tombolos, peninsulas, etc., driven by glacio-isostatic uplift and increased sediment input from proglacial environments, is to be expected. Changes are also likely in marine coastal environments due to increased sediment resuspension and mineralization that will induce changes in primary production (Fritz et al., 2017). Moreover, glacial retreat and permafrost degradation may also alter the biogeochemical cycles in the polar regions, with consequences for the climate system at regional and global scales (Hodson et al., 2017).

Research on paraglacial dynamics is more abundant in mountain areas (e.g. Ballantyne, 2008; McColl, 2012; Knight \& Harrison, 2014; Deline et al., 2015) than in polar regions (e.g. Mercier et al., 2009; Moreau et al., 2008); especially in the case of Antarctica, where there are only a few specific studies (Davies et al., 2013; Oliva \& Ruiz-Fernández, 2015). In contrast, paraglacial studies are abundant in mountain ranges such as the European Alps (Curry et al., 2006; Cossart, 2008; Kellerer-Pirklbauer et al., 2010; Eichel et al., 2013; Bosson et al., 2014), the Andes (Harrison et al., 2006; Riquelme et al., 2011), the Himalayas (Owen \& Sharma, 1998; Barnard et al., 2004), the Hindukush and Karakorum (Iturrizaga, 2008), and other mountainous areas such as the Scottish Highlands (Ballantyne, 2008; Ballantyne \& Stone, 2013). Some studies have even analyzed paraglacial dynamics occurring on large stratovolcanoes of Central America (Palacios et al., 1999). These investigations have addressed topics such as sediment transport, slope dynamics, associated fluvial and torrential processes, and the response on different time scales. Some of the most recent studies have also investigated the plant colonization of recently deglaciated areas in glacier forelands (Fickert \& Grüninger, 2018), the interaction between Alpine glaciers and rock glaciers (Kenner, 2019), and even the role of biogeomorphic interactions in the paraglacial stage (Eichel et al., 2013). Conceptual models and methodological approaches, mainly focused on mountain areas, have also constituted a line of preferential research (Ballantyne, 2002; Mercier, 2008; Knight \& Harrison, 2018).

Future research on this topic in Antarctica will allow a better understanding of the environmental dynamics of newly exposed ice-free areas. This will improve current knowledge gaps, such as the interaction between cold- and warm-based glaciers and permafrost, the loss of landmass, as well as the control exerted by the subglacial topography on the mobilization of sediments once glaciers have retreated (Oliva et al., 2019). Although time elapsed for soil formation and vegetation colonization can be highly variable depending on several factors (topography, climate, geomorphic disturbances, contribution of nutrients from wildlife colonies, interactions between bio- and geo-systems, etc.), the succession of processes and its chronology is still poorly understood. The formation of new ice-free 
areas also has important implications that have yet to be studied in detail, such as the creation of wildlife colonies.

Future research should also address the role that the nearshore zone plays in biogeochemical cycling in marine-terminating glaciers, which constitute large areas in Antarctica. Whereas Fritz et al. (2017) highlight the role that the sediment released due to coastal erosion - enhanced by permafrost degradation - has in the land-sea transition zone in the Arctic, a similar process may occur in recently deglaciated environments in Antarctica; in this case, it would be favored by both glacier retreat and permafrost degradation, although no studies have quantified it yet. The sediments reaching the sea may (i) transform into greenhouse gases, (ii) accelerate marine primary production, (iii) be buried nearshore, or (iv) be transported offshore (Fritz et al. 2017).

\section{Conclusions}

The AP, the warmest region of the Antarctic continent, represents a key area for the global climatic system. Increasing temperatures in the region may accelerate glacial retreat, which may have important consequences for local terrestrial and marine ecosystems but also implications at the global scale through altering ocean-atmospheric circulation patterns.

Past glacial retreat since the LGM has reshaped the configuration of the AP and surrounding islands, favoring the emergence of new land as well as the exposure of formerly glaciated environments. The shrinking and spatial retreat of glaciers has favored glacio-isostatic uplift, which has redefined coastlines, with the development of new islands, peninsulas, and other landforms. All these changes that occurred during the paraglacial stage promoted changes in the distribution pattern of flora and fauna, which in maritime Antarctica are mainly restricted to coastal fringes. Glacial retreat has also conditioned environmental dynamics, which have been more or less intense according to topography, the geomorphological setting and the presence or absence of permafrost.

The pronounced warming trend recorded during the second half of the $20^{\text {th }}$ century has accelerated some of these processes, as inferred from the geological record. The abundance and variety of records (glacial, periglacial, permafrost, alluvial, coastal) as well as observations of ecological processes, has shown evidence of the rapid paraglacial readjustment of AP environments during the transition from glacial to ice-free conditions. High uplift rates have continued to reshape coastlines, permafrost degradation in newly exposed areas is accelerating mass wasting and sediment redistribution and changing hydrological processes, and wildlife and flora are rapidly adapting to the new environmental setting.

All climate scenarios project a significant temperature increase by the end of the $21^{\text {st }}$ century in the AP region, which will lead to an increase in the extent of ice-free environments and therefore of the areas affected by paraglacial dynamics. In this context, an accurate characterization of the response of recently deglaciated environments following glacial retreat is critical for anticipating the future environmental responses in this highly sensitive climatic setting.

\section{Acknowledgements}

This research was supported by the project CRONOANTAR (Glacial evolution in King George and Livingston Islands (Antarctica) since the Last Glacial Maximum based on cosmogenic nuclide dating and glacier surface reconstruction) of the Spanish Ministry of Economy, Industry and Competitiveness (CTM2016-77878-P). Marc Oliva is supported by the Ramón y Cajal Program of the Spanish Ministry of Economy and Competitiveness (RYC-2015-17597). The Czech contribution has been supported by the Ministry of Education, Youth and Sports of the Czech Republic projects LM2015078 and CZ.02.1.01/0.0/0.0/16_013/0001708 and by the Masaryk University project MUNI/A/1419/2016. 


\section{References}

Amblas, D., Urgeles, R., Canals, M., Calafat, A.M., Rebesco, M., Camerlenghi, A., Estrada, F., De Batist, M., Hughes-Clarke, JE., 2006. Relationship between continental rise development and palaeo-ice sheet dynamics, Northern Antarctic Peninsula Pacific margin. Quat. Sci. Rev. 25, 933944. https://doi.org/10.1016/j.quascirev.2005.07.012.

Amesbury, M.J., Roland, T.P., Royles, J., Hodgson, D.A., Convey, P., Griffiths, H., Charman, D.J., 2017. Widespread Biological Response to Rapid Warming on the Antarctic Peninsula. Curr. Bio. 27, 1616-1622. https://doi.org/10.1016/j.cub.2017.04.034.

Anderson, J.B., Warny, S., Askin, R.A., Wellner, J.S., Bohaty, S.M., Kirshner, A.E., Livsey, D.N., Simms, A.R., Smith, T.R., Ehrmann, W., Lawver, L.A., Barbeau, D., Wise, S.W., Kulhenek, D.K., Weaver, F.M., Majewski, W., 2011. Progressive Cenozoic cooling and the demise of Antarctica's last refugium. Proc. Natl. Acad. Sci. U. S. A. 108, 11356-11360. https://doi.org/10.1073/pnas.1014885108.

Araya, R., Hervé, F., 1972. Periglacial phenomena in the South Shetland Islands, in: Adie, R.J. (Ed.), Antarctic Geology and Geophysics: International Union of Geological Science Series, 1, pp. 105109.

Balks, M., López-Martínez, J., Goryachkin, S.V., Mergelov, N., Schaefer, C.E.G.R., Simas, F.N.B., Almond, P.C., Claridge, G.G.C., McLeod, M., Scarrow, J., 2013. Windows on Antarctic soil landscape relationships: comparison across selected regions of Antarctica. Geol. Soc. Lond. Spec. Publ. 381, 397-410. https://doi.org/10.1144/SP381.9.

Ballantyne, C.K., 2002. Paraglacial geomorphology. Quat. Sci. Rev. 21, 1935-2017. https://doi.org/10.1016/S0277-3791(02)00005-7.

Ballantyne, C.K., 2008. After the ice: Holocene geomorphic activity in the Scottish Highlands. Scott. Geogr. J. 124, 8-52. https://doi.org/10.1080/14702540802300167.

Ballantyne, C.K., Stone, J.O., 2013. Timing and periodicity of paraglacial rock-slope failures in the $\begin{array}{llll}\text { Scottish Highlands. } & \text { Geomorphology }\end{array}$ https://doi.org/10.1016/j.geomorph.2012.12.030.

Balco, G., Schaefer, J.M., LARISSA group, 2013. Exposure-age record of Holocene ice sheet and ice shelf change in the northeast Antarctic Peninsula. Quat. Sci. Rev. 59, 101-111. https://doi.org/10.1016/j.quascirev.2012.10.022.

Banfield, L.A., Anderson, J.B., 2013. Seismic facies investigation of the Late Quaternary glacial history of Bransfield Basin, Antarctica. Geology and Seismic Stratigraphy of the Antarctic Margin. Antarct. Res. Ser. 68, 123-140. https://doi.org/10.1029/AR068p0123.

Barbara, L., Crosta, X., Leventer, A., Schmidt, S., Etourneau, J., Domack, E., Massé, G., 2016. Environmental responses of the Northeast Antarctic Peninsula to the Holocene climate variability. Paleoceanogr. 31, 131-147. https://doi.org/10.1002/2015PA002785.

Barnard, P.L., Owen, L., Finkel, R.C., 2004. Style and timing of glacial and paraglacial sedimentation in a monsoon-influenced high Himalayan environment, the upper Bhagirathi Valley, Garhwal Himalaya. Sedimentary Geol. 165(3-4), 199-221. https://doi.org/10.1016/j.sedgeo.2003.11.009

Bentley, M.J., Fogwill, C.J., Kubik, P.W., Sugden, D.E., 2006. Geomorphological evidence and cosmogenic 10Be/26Al exposure ages for the Last Glacial Maximum and deglaciation of the Antarctic Peninsula Ice Sheet. Geol. Soc. Am. Bull. 118, 1149-1159. https://doi.org/10.1130/B25735.1.

Bentley, M.J., Fogwill, C.J., Le Brocq, A.M., Hubbard, A.L., Sugden, D.E., Dunai, T.J., Freeman, S.P.H.T., 2010. Deglacial history of the West Antarctic Ice Sheet in the Weddell Sea embayment: Constraints on past Ice volume change. Geology 38, 411-414. https://doi.org/10.1130/G30754.1.

Bentley, M.J., Johnson, J.S., Hodgson, D.A., Dunai, T., Freeman, S.P.H.T., Ó Cofaigh, C., 2011. Rapid deglaciation of Marguerite Bay, western Antarctic Peninsula in the Early Holocene. Quat. Sci. Rev. 30, 3338-3349. https://doi.org/10.1016/j.quascirev.2011.09.002.

Bentley, M.J., Hodgson, D.A., Smith, J.A., Cox, N., 2005a. Relative sea level curves for the South Shetland Islands and Marguerite Bay, Antarctic Peninsula. Quat. Sci. Rev. 24, 1203-1216. https://doi.org/10.1016/j.quascirev.2004.10.004.

Bentley, M.J., Hodgson, D.A., Smith, J.A., Ó Cofaigh, C., Domack, E.W., Larter, R.D., Roberts, S.J., Brachfeld, S., Leventer, A., Hjort, C., Hillenbrand, C.D., Evans, J., 2009. Mechanisms of 
Holocene palaeoenvironmental change in the Antarctic Peninsula region. The Holocene 19, 5169. https://doi.org/10.1177/0959683608096603.

Bentley, M.J., Hodgson, D.A., Sugden, D., Roberts, S., Smith, J., Leng, M., Bryant, C., 2005b. Early Holocene retreat of the George VI Ice Shelf, Antarctic Peninsula. Geology 33, 173-176. https://doi.org/10.1130/G21203.1.

Birkenmajer, K., 1988. Report on the Polish geological investigations in the Antarctic Peninsula sector, 1987-1988. Pol. Polar Res. 9, 505-519.

Björck, S., Håkansson, H., Zale, R., Karlén, W., Jönsson, B.L., 1991. A late Holocene lake sediment sequence from Livingston Island, South Shetland Islands, with palaeoclimatic implications. Antarct. Sci. 3, 61-72. https://doi.org/10.1017/S095410209100010X.

Björck, S., Malmer, N., Hjort, C., Sandgren, P., Ingolfsson, O., Wallen, B., Smith, R.I.L., Jonsson, B.L., 1991. Stratigraphic and palaeoclimate studies of a 5500-year-old moss bank on Elephant Island, Antarctica. Arct. Antarct. Alp. Res. 23, 361-374.

Björck, S., Olsson, S., Ellis-Evans, C., Håkansson, H., Humlum, O., Lirio, J.M. 1996. Late Holocene palaeoclimatic records from lake sediments on James Ross Island, Antarctica. Palaeogeogr. Palaeoclimatol. Palaeoecol. 121, 195-220. https://doi.org/10.1016/0031-0182(95)00086-0.

Blume, H.P., Kuhn, D., Bölter, M., 2002. Weathering and soil formation. In: Beyer, L., Bölter, M., (Eds.), Geoecology of Antarctic ice-free coastal landscapes. Ecological studies. Springer, Berlin. 154 , pp. 115-138.

Bockheim, J., Vieira, G., Ramos, M., López-Martínez, J., Serrano, E., Guglielmin, M., Wilhelm, K., Nieuwendam, A., 2013. Climate warming and permafrost dynamics in the Antarctic Peninsula region. Glob. Planet. Chang. 100, 215-223. https://doi.org/10.1016/j.gloplacha.2012.10.018.

Bohuslavová, O., Macek, P., Redčenko, O., Láska, K., Nedbalová, L. and Elster, J., 2018. Dispersal of lichens along a successional gradient after deglaciation of volcanic mesas on northern James Ross Island, Antarctic Peninsula. Polar Biol. 41, 1-12. https://doi.org/10.1007/s00300-018-2357-7

Bokhorst, S., Huiskes, A., Convey, P., Aerts, R., 2007. External nutrient inputs into terrestrial ecosystems of the Falkland Islands and the Maritime Antarctic region. Polar Biol. 30, 1315-1321. https://doi.org/10.1007/s00300-007-0292-0.

Bosson, J.B., Deline, P., Bodin, X., Schoeneich, P., Baron, L., Gardent, M. \& Lambiel, C., 2015. The influence of ground ice distribution on geomorphic dynamics since the Little Ice Age in proglacial areas of two cirque glacier systems. Earth Surf. Process. Landf. 40(5), 666-680. https://doi.org/10.1002/esp.3666.

Boy, J., Godoy, R., Shibistova, O., Boy, D., McCulloch, R., Andrino de la Fuente, A., Aguirre Morales, M., Mikutta, R., Guggenberger, G., 2106. Successional patterns along soil development gradients formed by glacier retreat in the Maritime Antarctic, King George Island. Revista Chilena de Historia Natural. 89, 1-6. https://doi.org/10.1186/s40693-016-0056-8.

Brachfeld, S., Domack, E., Kissel, C., Laj, C., Leventer, A., Ishman, S., Gilbert, R., Camerlenghi, A., Eglinton, L.B., 2003. Holocene history of the Larsen-A Ice Shelf constrained by geomagnetic paleointensity dating. Geology 31, 749-752. https://doi.org/10.1130/G19643.1.

Bradley, J.A., Singarayer, J.S., Anesio, A.M., 2014. Microbial community dynamics in the forefield of glaciers. Proc. R. Soc. Ser. B 281, 20140882. https://doi.org/10.1098/rspb.2014.0882.

Burton-Johnson, A., Black, M., Fretwell, P.T., Kaluza-Gilbert, J., 2016. An automated methodology for differentiating rock from snow, clouds and sea in Antarctica from Landsat 8 imagery: a new rock outcrop map and area estimation for the entire Antarctic continent. Cryosphere. 10, 16651677. https://doi.org/10.5194/tc-10-1665-2016.

Burton-Johnson, A., Riley, T.R., 2015. Autochthonous v. accreted terrane development of continental margins: a revised in situ tectonic history of the Antarctic Peninsula. J. Geol. Soc. 172, 822-835. https://doi.org/10.1144/jgs2014-110.

Campo, J.M., Wellner, J.S., Domack, E., Lavoie, C., Yoo, K.C., 2017. Glacial geomorphology of the northwestern Weddell Sea, eastern Antarctic Peninsula continental shelf: Shifting ice flow patterns during deglaciation. Geomorphology 280, 89-107. https://doi.org/10.1016/j.geomorph.2016.11.022.

Canals, M., Urgeles, R., Calafat, A.M., 2000. Deep sea-floor evidence of past ice streams off the Antarctic Peninsula. Geology 28, 31-34. https://doi.org/10.1130/0091-7613. 
Cannone, N., Corinti, T., Malfasi, F., Gerola, P., Vianelli, A., Vanetti, I., Zaccara, S., Convey, P., Guglielmin, M., 2017b. Moss survival through in situ cryptobiosis after six centuries of glacier burial. Sci. Rep. 7, 4438. https://doi.org/10.1038/s41598-017-04848-6.

Cannone, N., Dalle Fratte, M., Convey, P., Worland, M.R., Guglielmin, M., 2017a. Ecology of moss banks on Signy Island (maritime Antarctic). Bot. J. Linn. Soc. 184, 518-533. https://doi.org/10.1093/botlinnean/box040.

Cannone, N., Guglielmin, M., 2008. Patterned ground features and vegetation. Examples from Continental and Maritime Antarctica. In: Proceedings of 9th International Conference on Permafrost. University of Alaska Fairbanks, Alaska, 29, 227-231.

Carrivick, J.L., Davies, B.J., Glasser, N.F., Nývlt, D., Hambrey, M.J., 2012. Late-Holocene changes in character and behaviour of land-terminating glaciers on James Ross Island, Antarctica. J. Glaciol. 58, 1176-1190. https://doi.org/10.3189/2012JoG11J148.

Cavieres, L.A., Sáez, P., Sanhueza, C., Sierra-Almeida, A., Rabert, C., Corcuera, L.J., Alberdi, M., Bravo, L.A., 2016. Ecophysiological traits of Antarctic vascular plants: their importance in the responses to climate change. Plant Ecol. 2173, 343-358. https://doi.org/10.1007/s11258-0160585-x.

Convey, P., Smith, R.I.L., 2006. Responses of terrestrial Antarctic ecosystems to climate change. Plant Ecol. 182, 1-10. https://doi.org/10.1007/s11258-005-9022-2.

Cook, A.J., Fox, A.J., Vaughan, D.G., Ferrigno, J.G., 2005. Retreating glacier fronts on the Antarctic Peninsula over the past half-century. Science 308, 541-544. https://doi.org/10.1126/science.1104235

Cook, A.J., Holland, P.R., Meredith, M.P., Murray, T., Luckman, A., Vaughan, D.G., 2016. Ocean forcing of glacier retreat in the western Antarctic Peninsula. Science 353, 283-286. https://doi.org/10.1126/science.aae0017.

Cook, A.J., Vaughan, D.G., 2010. Overview of areal changes of the ice shelves on the Antarctic Peninsula over the past 50 years. Cryosphere. 4, 77-98. https://doi.org/10.5194/tc-4-77-2010.

Corner, R.W.M., Smith, R.I.L., 1973. Botanical evidence of ice recession in the Argentine Islands. Br. Antarct. Surv. Bull. 35, 83-86.

Correia, A., Oliva, M., Ruiz-Fernández, J., 2017. Evaluation of frozen ground conditions along a coastal topographic gradient at Byers Peninsula (Livingston Island, Antarctica) by geophysical and geoecological methods. Catena 149, 529-537. https://doi.org/10.1016/j.catena.2016.08.006.

Cossart E. 2008. Landform connectivity and waves of negative feedbacks during the paraglacial period, a case study: the Tabuc subcatchment since the end of the Little Ice Age (massif des Écrins, France). Géomorphologie: relief, processus, environnement 4, 249-260.

Cowan, E.A., Hillenbrand, C.D., Hassler, L.E., Ake, M.T., 2008. Coarse-grained terrigenous sediment deposition on continental rise drifts: A record of Plio-Pleistocene glaciation on the Antarctic Peninsula. Palaeogeogr. Palaeoclimatol. Palaeoecol. 265, 275-291. https://doi.org/10.1016/j.palaeo.2008.03.010.

Curry, A.M., Cleasby, V. \& Zukowskyj, P. (2006). Paraglacial response of steep, sediment-mantled slopes to post-'Little Ice Age'glacier recession in the central Swiss Alps. J. Quat. Sci. 21(3), 211225. https://doi.org/10.1002/jqs.954.

Davies, B.J., Carrivick, J.L., Glasser, N.F., Hambrey, M.J., Smellie, J.L., 2012a. Variable glacier response to atmospheric warming, northern Antarctic Peninsula, 1988-2009. Cryosphere. 6, 1031-1048. https://doi.org/10.5194/tc-6-1031-2012.

Davies, B.J., Glasser, N.F., Carrivick, J.L., Hambrey, M.J., Smellie, J.L., Nývlt, D., 2013. Landscape evolution and ice-sheet behaviour in a semi-arid polar environment: James Ross Island, NE Antarctic Peninsula. Geol. Soc. Lond. Spec. Publ. 381, 353-395. https://doi.org/10.1144/SP381.1.

Davies, B.J., Golledge, N.R., Glasser, N.F., Carrivick, J.L., Ligtenberg, S.R.M., Barrand, N.E., van den Broeke, M.R., Hambrey, M.J., Smellie, J.L., 2014. Modelled glacier response to centennial temperature and precipitation trends on the Antarctic Peninsula. Nat. Clim. Change 4, 993-998, 10.1038/nclimate2369.

Davies, B.J., Hambrey, M.J., Smellie, J.L., Carrivick, J.L., Glasser, N.F., 2012b. Antarctic Peninsula Ice Sheet evolution during the Cenozoic Era. Quat. Sci. Rev. 31, 30-66. https://doi.org/10.1016/j.quascirev.2011.10.012. 
Del Valle, R.A., Montalti, D., Inbar, M., 2002. Mid-Holocene macrofossil-bearing raised marine beaches at Potter Peninsula, King George Island, South Shetland Islands. Antarct. Sci. 14, 263 269. https://doi.org/10.1017/S0954102002000081.

Deline, P., Gruber, S., Delaloye, R., Fischer, L., Geertsema, M., Giardino, M., Hasler, A., Kirkbride, M., Krautblatter, M., Magnin, F., McColl, S., 2015. Ice loss and slope stability in high-mountain regions, in: Snow and Ice-related Hazards, Risks and Disasters, pp. 521-561.

Dingle, R.V., Lavelle, M., 1998. Antarctic Peninsular cryosphere: Early Oligocene (c. 30 Ma) initiation and a revised glacial chronology. J. Geol. Soc. 155, 433-437. https://doi.org/10.1144/gsjgs.155.3.0433.

Domack, E., Duran, D., Leventer, A., Ishman, S., Doane, S., McCallum, S., Amblas, D., Ring, J., Gilbert, R., Prentice, M., 2005. Stability of the Larsen B ice shelf on the Antarctic Peninsula during the Holocene epoch. Nature 436, 681-685. https://doi.org/10.1038/nature03908.

Domack, E., Ishman, W., Stein, S.E., McClennen, C.E., Jull, A.J.T., 1995. Late Holocene advance of Muller Ice Shelf, Antarctic Peninsula: Sedimentological, geochemical and palaeontological evidence. Antarct. Sci. 7, 159-170. https://doi.org/10.1017/S0954102095000228.

Domack, E., Leventer, A., Dunbar, R., Taylor, F., Brachfeld, S., Sjunneskog, C., 2001. Chronology of the Palmer Deep site, Antarctic Peninsula: a Holocene palaeoenvironmental reference for the circum-Antarctic. The Holocene 11, 1-9. https://doi.org/10.1191/095968301673881493.

Dunning, S., Westoby, M., Woodward, J., Hein, A., Marrero, S., 2016. Rockfall erosion in Antarctica as a significant agent of change above ice. Geophys. Res. Abstr. 18, 4690.

Eichel, J., Krautblatter, M., Schmidtlein, S., Dikau, R. (2013). Biogeomorphic interactions in the Turtmann glacier forefield, Switzerland. Geomorphology, 201, 98-110. https://doi.org/10.1016/j.geomorph.2013.06.012.

Elster, J., 2008. Ecological background of cyanobacterial assemblages of the northern part of James Ross Island, Antarctica. Pol. Polar Res. 29, 17-32.

Emslie, S.D., Fraser, W., Smith, R.C., Walker, W., 1998. Abandoned penguin colonies and environmental change in the Palmer Station area, Anvers Island, Antarctic Peninsula. Antarct. Sci. 10, 257-268.

Emslie, S.D. 2001. Radiocarbon dates from abandoned penguin colonies in the Antarctic Peninsula region. Antarct. Sci. 13, 289-295.

Emslie, S.D., McDaniel, J., 2002. Adélie penguin diet and climate change during the middle to late Holocene in northern Marguerite Bay, Antarctic Peninsula. Polar Biol. 25, 222-229.

Engel, Z., Láska, K., Nývlt, D., Stachoň, Z., 2018. Surface mass balance of small glaciers on James Ross Island, north-eastern Antarctic Peninsula, during 2009-2015. J. Glaciol. 64, 349-361, 10.1017/jog.2018.17.

Engel, Z, Nývlt, D., Láska, K., 2012. Ice thickness, areal and volumetric changes of Davies Dome and Whisky Glacier (James Ross Island, Antarctic Peninsula) in 1979-2006. J. Glaciol. 58, 904-914. https://doi.org/10.3189/2012JoG11J156.

Engelen, A., Convey, P., Hodgson, D.A., Worland, M.R., Ott, S., 2008. Soil properties of an Antarctic inland site: implications for ecosystem development. Polar Biol. 31, 1453-1460. https://doi.org/10.1007/s00300-008-0486-0.

Engelen, A., Convey, P., Ott, S., 2010. Life history strategy of Lepraria borealis at an Antarctic inland site, Coal Nunatak. The Lichenologist 42, 339-346. https://doi.org/10.1017/S0024282909990600.

Ermolin, E., De Angelis, H., Skvarca, P., 2002. Mapping of permafrost on Vega Island, Antarctic Peninsula, using satellite images and aerial photography. Ann. Glaciol. 34, 184-188. https://doi.org/10.3189/172756402781817824.

Evans, J., Pudsey, C.J., Ó, Cofaigh, C., Morris, P., Domack, E., 2005. Late Quaternary glacial history, flow dynamics and sedimentation along the eastern margin of the Antarctic Peninsula Ice Sheet. Quat. Sci. Rev, 24, 741-774. https://doi.org/10.1016/j.quascirev.2004.10.007.

Favero-Longo, S., Worland, M.R., Convey, P., Smith, R.I.L., Piervittori, R., Guglielmin, M., Cannone, N., 2012. Primary succession of lichen and bryophyte communities following glacial recession on Signy Island, South Orkney Islands, Maritime Antarctic. Antarct. Sci. 24, 323-336. https://doi.org/10.1017/S0954102012000120. 
Fenton, J.H.C., 1982. Vegetation re-exposed after burial by ice and its relationship to changing climate in the South Orkney Islands. Br. Antarct. Surv. Bull. 51, 247-255.

Fenton, J.H.C., Smith, R.I.L. ,1982. Distribution, composition and general characteristics of the moss banks of the maritime Antarctic. Br. Antarct. Surv. Bull. 51, 215-236.

Fickert, T., Grüninger, F., 2018. High-speed colonization of bare ground-Permanent plotstudies on primary succession of plants in recently deglaciatedglacier forelands. Land Degrad. Dev. 29, 2668-2680. https://doi.org/10.1002/ldr.3063.

Fitzsimons, S.J., 1996. Paraglacial redistribution of glacial sediments in the Vestfold Hills, East Antarctica. Geomorphology 15, 93-108. https://doi.org/10.1016/0169-555X(95)00122-L.

Francelino, M.R., Schaefer, C.E., Simas, F., Fernandes, E.I., Leal, J.J., da Costa, L.M., 2011. Geomorphology and soils distribution under paraglacial conditions in an ice-free area of Admiralty Bay, King George Island, Antarctica. Catena 85, 194-204. https://doi.org/10.1016/j.catena.2010.12.007.

Fretwell, P.T., Hodgson, D.A., Watcham, E.P., Bentley, M.J., Roberts, S.J., 2010. Holocene isostatic uplift of the South Shetland Islands, Antarctic Peninsula, modelled from raised beaches. Quat. Sci. Rev. 29, 1880-1893. https://doi.org/10.1016/j.quascirev.2010.04.006.

Fritz, M., Vonk, J.E., Lantuit, H., 2017. Collapsing Arctic coastlines. Nat. Clim. Chang. 7, 6-7. https://doi.org/10.1038/nclimate3188.

Fukui, K., Sone, T., Strelin, J., Torielli, C., Mori, J., 2007. Ground penetrating radar sounding on an active rock glacier on James Ross Island, Antarctic Peninsula region. Pol. Polar Res. 28, 13-22.

Fukui, K., Sone, T., Strelin, J.A., Torielli, C., Mori, J., Fujii, Y., 2008. Dynamics and GPR stratigraphy of a polar rock glacier on James Ross Island, Antarctic Peninsula. J. Glaciol. 54, 445-451.

Glasser, N.F., Davies, B.J., Carrivick, J.L., Rodés, A., Hambrey, M.J., Smellie, J.L., Domack, E., 2014. Ice-stream initiation, duration and thinning on James Ross Island, northern Antarctic Peninsula. Quat. Sci. Rev. 86, 78-88. https://doi.org/10.1016/j.quascirev.2013.11.012.

Glasser, N.F., Scambos, T.A., 2008. A structural glaciological analysis of the 2002 Larsen B ice-shelf collapse. J. Glaciol. 54, 3-16. https://doi.org/10.3189/002214308784409017.

González-Guzmán, A., Oliva, M., Souza-Júnior, V.S., Pérez-Alberti, A., Ruiz-Fernández, J., Otero, X.L., 2017. Biota and geomorphic processes as key environmental factors controlling soil formation at Elephant Point, Maritime Antarctica. Geoderma 300, 32-43. https://doi.org/10.1016/j.geoderma.2017.04.001.

Gordon, J.E., Birnie, R., Timmis, R., 1978. A major rockfall and debris slide on the Lyell Glacier, South Georgia. Arct. Antarct. Alp. Res. 10, 49-60. https://doi.org/10.2307/1550656.

Graham, A.G.C., Smith, J.A., 2012. Palaeoglaciology of the Alexander Island ice cap, western Antarctic Peninsula, reconstructed from marine geophysical and core data. Quat. Sci. Rev. 35, 63-81. https://doi.org/10.1016/j.quascirev.2012.01.008.

Grämiger, L.M., Moore, J.R., Gischig, V.S., Ivy-Ochs, S., Loew, S., 2017. Beyond debuttressing: Mechanics of paraglacial rock slope damage during repeat glacial cycles. J. Geophys. Res.: Earth Surface. https://doi.org/10.1002/2016JF003967.

Guglielmin, M., Boschi, D., D’Agata, C., Ellis-Evans, C., Worland, M.R., 2008. Periglacial and permafrost map of Signy Island, South Orkneys Islands, Maritime Antarctica, in: Kane, D.L., Hinkel, K.M. (Eds.), Proceedings of 9th International Conference on Permafrost. University of Alaska Fairbanks, Alaska, 1, pp. 569-574.

Guglielmin, M., Convey, P., Malfasi, F., Cannone, N., 2016. Glacial fluctuations since the 'Medieval Warm Period' at Rothera Point (western Antarctic Peninsula). The Holocene 26, 154-158. https://doi.org/10.1177/0959683615596827.

Guglielmin, M., Ponti, S., Forte, E., 2018. The origins of Antarctic rock glaciers: periglacial or glacial features? Earth Surf. Process. Landf. 43, 1390-1402. https://doi.org/10.1002/esp.4320

Guglielmin, M., Worland, R.M., Baio, F., Baio, F., Convey, P., 2014. Permafrost and snow monitoring at Rothera Point (Adelaide Island, Maritime Antarctica): Implications for rock weathering in cryotic conditions. Geomorphology 225, 47-56. https://doi.org/10.1016/j.geomorph.2014.03.051.

Guglielmin, M., Worland, R., Convey, P., Cannone, N., 2012. Schmidt hammer studies in the maritime Antarctic: Application to dating Holocene deglaciation and estimating the effects of macrolichens 
on rock weathering. Geomorphology $\quad$ 155, 34-44. https://doi.org/10.1016/j.geomorph.2011.12.015.

Hall, B.L., 2009. Holocene glacial history of Antarctica and the sub-Antarctic islands. Quat. Sci. Rev. 2821, 2213-2230. https://doi.org/10.1016/j.quascirev.2009.06.011.

Hall, B.L., 2010. Holocene relative sea-level changes and ice fluctuations in the South Shetland Islands. Glob. Planet. Chang. 74, 15-26. https://doi.org/10.1016/j.gloplacha.2010.07.007.

Hall, B.L., Perry, E.R., 2004. Variations in ice rafted detritus on beaches in the South Shetland Islands: a possible climate proxy. Antarct. Sci. 16, 339-344. https://doi.org/10.1017/S0954102004002147.

Hall, K., 1997. Rock temperatures and implications for cold region weathering: I. New data from Viking Valley, Alexander Island (Antarctica). Permafr. Periglac. Process. 8, 69-90. https://doi.org/10.1002/(SICI)1099-1530(199701)8:1<69::AID-PPP236>3.0.CO;2-Q.

Hansom, J.D., 1979. Radiocarbon dating of a raised beach at $10 \mathrm{~m}$ in the South Shetland Islands, Antarctica. Marine Geology 53, 211-229.

Harrison, S., Glasser, N., Winchester, V., Haresign, E., Warren, C., Jansson, K., 2006. A glacial lake outburst flood associated with recent mountain glacier retreat, Patagonian Andes. The Holocene 16(4), 611-620. https://doi.org/10.1191/0959683606hl957rr.

Hepp, D.A., Mörz, T., Grützner, J., 2006. Pliocene glacial cyclicity in a deep-sea sediment drift (Antarctic Peninsula Pacific Margin). Palaeogeogr. Palaeoclimatol. Palaeoecol. 231, 181-198. https://doi.org/10.1016/j.palaeo.2005.07.030.

Heroy, D.C., Anderson, J.B., 2005. Ice-sheet extent of the Antarctic Peninsula region during the Last Glacial Maximum (LGM) - Insights from glacial geomorphology. Geol. Soc. Am. Bull. 117, 1497-1512. https://doi.org/10.1130/B25694.1.

Heroy, D.C., Anderson, J.B., 2007. Radiocarbon constraints on Antarctic Peninsula Ice Sheet retreat following the Last Glacial Maximum (LGM). Quat. Sci. Rev. 26, 3286-3297. https://doi.org/10.1016/j.quascirev.2007.07.012

Heroy, D.C., Sjunneskog, C., Anderson, J.B., 2008. Holocene climate change in the Bransfield Basin, Antarctic Peninsula: Evidence from sediment and diatom analysis. Antarct. Sci. 20, 69-87. https://doi.org/10.1017/S0954102007000788.

Hjort, C., Ingólfsson, Ó., Möller, P., Lirio, J., 1997. Holocene glacial history and sea-level changes on James Ross Island, Antarctic Peninsula. J. Quat. Sci. 12, 259-273. https://doi.org/10.1002/(SICI)1099-1417(199707/08)12:4<259::AID-JQS307>3.0.CO;2-6.

Hodgson, D.A., Roberts, S.J., Bentley, M.J., Smith, J.A., Johnson, J.S., Verleyen, E., Vyverman, W., Hodson, A.J., Leng, M.J., Cziferszky, A., Fox, A.J., Sanderson, D.C.W., 2009. Exploring former subglacial Hodgson Lake, Antarctica Paper I: site description, geomorphology and limnology. Quat. Sci. Rev. 28, 2295-2309. https://doi.org/10.1016/j.quascirev.2009.04.011.

Hodgson, D.A., Roberts, S.J., Smith, J.A., Verleyen, E., Sterken, M., Labarque, M., Sabbe, K., Vyverman, W., Allen, C.S., Leng, M.J., Bryant, C. 2013. Late Quaternary environmental changes in Marguerite Bay, Antarctic Peninsula, inferred from lake sediments and raised beaches. Quat. Sci. Rev. 68, 216-236. https://doi.org/10.1016/j.quascirev.2013.02.002.

Hodson, A., Nowak, A., Sabacka, M., Jungblut, A., Navarro, F., Pearce, D., Ávila-Jiménez, M.L., Convey, P., Vieira, G., 2017. Climatically sensitive transfer of iron to maritime Antarctic ecosystems by surface runoff. Nat. Commun. 8, 14499. https://doi.org/10.1038/ncomms14499.

Holzhauser, H., Magny, M., Zumbühl, H.J., 2005. Glacier and lake-level variations in west-central Europe over the last 3500 years. The Holocene 15, 789-801. https://doi.org/10.1191/0959683605hl853ra.

Hrbáček, F., Oliva, M., Láska, K., Ruiz-Fernández, J., de Pablo, M.A., Vieira, G., Ramos, M., Nývlt, D., 2016. Active layer termal regime in two climatically contrasted sites of the Antarctic Peninsula Region. Cuadernos de Investigación Geográfica 42(2), 457-474.

Humlum, O., 1996. Origin of Rock Glaciers: Observations from Mellemfjord, Disko Island, Central West Greenland. Permafr. Periglac. Process. 7, 361-380.

IMBIE team, 2018. Mass balance of the Antarctic Ice Sheet from 1992 to 2017. Nature 558, 219-222, 10.1038/s41586-018-0179-y.

Ingólfsson, Ó., 2004. Quaternary glacial and climate history of Antarctica. Dev. Quat. Sci. 2, 3-43. https://doi.org/10.1016/S1571-0866(04)80109-X. 
Ingólfsson, Ó., Hjort, C., Björck, S., Smith, R.I.L., 1992. Late Pleistocene and Holocene glacial history of James Ross Island, Antarctic Peninsula. Boreas 21, 209-222. https://doi.org/10.1111/j.15023885.1992.tb00029.x.

Ingólfsson, Ó., Hjort, C., Humlum, O., 2003. Glacial and climate history of the Antarctic Peninsula since the Last Glacial Maximum. Arct. Antarct. Alp. Res. 35, 175-186. https://doi.org/10.1657/1523-0430(2003)035[0175:GACHOT]2.0.CO;2.

Iturrizaga, L., 2008. Paraglacial landform assemblages in the Hindukush and Karakoram Mountains. Geomorphology 95, 27-47. https://doi.org/10.1016/j.geomorph.2006.07.030.

Ivany, L.C., Van Simaeys, S., Domack, E.W., Samson, S.D., 2006. Evidence for an earliest Oligocene ice sheet on the Antarctic Peninsula. Geology 34, 377-380. https://doi.org/10.1130/G22383.1.

Jamieson, S.S.R., Vieli, A., Livingstone, S.J., Ó Cofaigh, C., Stokes, C., Hillenbrand, C.D., Dowdeswell, J.A. 2012. Ice-stream stability on a reverse bed slope. Nat. Geosci. 5, 799-802. https://doi.org/10.1038/ngeo1600.

Janiec, K., 1996. Short distance wind transport of microfauna in maritime Antarctic King George Island, South Shetland Islands. Pol. Polar Res. 173, 3-4.

John, B.S., Sugden, D.E., 1971. Raised marine features and phases of glaciation in the South Shetland Islands. Br. Antarct. Surv. Bull. 24, 45-111.

Johnson, J.S., Bentley, M.J., Roberts, S.J., Binnie, S.A., Freeman, S.P.H.T., 2011. Holocene deglacial history of the northeast Antarctic Peninsula - A review and new chronological constraints. Quat. Sci. Rev. 30, 3791-3802. https://doi.org/10.1016/j.quascirev.2011.10.011.

Johnson, J.S., Everest, J.D., Leat, P.T., Golledge, N.R., Rood, D.H., Stuart, F.M., 2012. The deglacial history of NW Alexander Island, Antarctica, from surface exposure dating. Quat. Res. 77, 273280. https://doi.org/10.1016/j.yqres.2011.11.012.

Johnson, J.S., Smellie, J.L., Nelson, A.E. \& Stuart, F.M., 2009. History of the Antarctic Peninsula Ice Sheet since the early Pliocene-Evidence from cosmogenic dating of Pliocene lavas on James Ross Island, Antarctica. Global and Planetary Change 69, 205-213, 10.1016/j.gloplacha.2009.09.001.

Jones, V.J., Hodgson, D.A., Chepstow-Lusty, A., 2000. Palaeolimnological evidence for marked Holocene environmental changes on Signy Island, Antarctica. The Holocene 10, 43-60. https://doi.org/10.1191/095968300673046662.

Kavan, J., Nývlt, D. 2018. Blowing in the wind - where does the Antarctic fluvial suspended load come from? In: Polar 2018. Where the Poles come together. Abstract Proceedings. Wed_93_CR2_332, p. 870, Davos, Switzerland.

Kavan, J., Ondruch, J., Nývlt, D., Hrbáček, F., Carrivick, J.L., Láska, K., 2017. Seasonal hydrological and suspended sediment transport dynamics in proglacial streams, James Ross Island, Antarctica. Geogr. Ann. Ser. A, 97, 38-55. https://doi.org/10.1080/04353676.2016.1257914.

Kellerer-Pirklbauer, A., Proske, H., Strasser, V., 2010. Paraglacial slope adjustment since the end of the Last Glacial Maximum and its long-lasting effects on secondary mass wasting processes: Hauser Kaibling, Austria. Geomorphology 120, 65-76. https://doi.org/10.1016/j.geomorph.2009.09.016.

Kenner, R. (2019). Geomorphological analysis on the interaction of Alpine glaciers and rock glaciers since the Little Ice Age. Land Degrad. Dev. https://doi.org/10.1002/ldr.3238

Kilfeather, A.A., Ó Cofaigh, C., Lloyd, J.M., Dowdeswell, J.A., Xu, S., Moreton, S.G., 2011. Ice-stream retreat and ice-shelf history in Marguerite Trough, Antarctic Peninsula: Sedimentological and foraminiferal signatures. Geol. Soc. Am. Bull. 123, 997-1015. https://doi.org/10.1130/B30282.1.

Knight, J., Harrison, S., 2014. Mountain glacial and paraglacial environments under global climate change: Lessons from the past, future directions and policy implications. Geogr. Ann. Ser. A, 96(3), 245-264. https://doi.org/10.1111/geoa.12051.

Knight, J., Harrison, S., 2018. Transience in cascading paraglacial systems. Land Degrad. Dev. 29(6), 1991-2001. https://doi.org/10.1002/ldr.2994.

Kopalová, K., Nedbalová, L., Nývlt, D., Elster, J., Van de Vijver, B., 2013. Diversity, ecology and biogeography of the freshwater diatom communities from Ulu Peninsula (James Ross Island, NE Antarctic Peninsula). Polar Biol. 36, 933-948. https://doi.org/10.1007/s00300-013-1317-5.

Kozeretska, I.A., Parnikoza, I.Y., Mustafa, O., Tyschenko, O.V., Korsun, S.G., Convey, P., 2010. Development of Antarctic herb tundra vegetation near Arctowski station, King George Island. Polar Sci. 3, 254-261. https://doi.org/10.1016/j.polar.2009.10.001. 
Láska, K., Barták, M., Hájek, J., Prošek, P., Bohuslavová, O., 2011. Climatic and ecological characteristics of deglaciated area of James Ross Island, Antarctica, with a special respect to vegetation cover. Czech Polar Rep. 1, 49-62. https://doi.org/10.5817/CPR2011-1-5.

Lecomte, K.L., Vignoni, P.A., Córdoba, F.E., Chaparro, M.A.E., Chaparro, M.A.E., Kopalová, K., Gargiulo, J.D., Lirio, J.M., Irurzun, M.A., Böhnel, H.N., 2016. Hydrological systems from the Antarctic Peninsula under climate change: James Ross archipelago as study case. Environ. Earth Sci. 75. 623. https://doi.org/10.1007/s12665-016-5406-y.

Livingstone, S.J., Ó Cofaigh, C., Stokes, C.R., Hillenbrand, C.D., Vieli, A., Jamieson, S.S.R., 2012. Antarctic palaeo-ice streams. Earth-Sci. Rev. 111, 90-128. https://doi.org/10.1016/j.earscirev.2011.10.003

López-Martínez, J., Martínez de Pisón, E., Serrano, E., Arche, A., 1996. Geomorphological map of Byers Peninsula, Livingston Island. British Antarctic Survey, Cambridge, UK. BAS Geomap Series, Sheet 5-A.

López-Martínez, J., Schmid, T., Serrano, E., Mink, S., Nieto, A., Guillaso, S., 2016. Geomorphology and surface landforms distribution in selected ice-free areas within the South Shetland Islands, northern Antarctic Peninsula region. Cuadernos de Investigación Geográfica 42(2), 435-455. https://doi.org/10.18172/cig.2965.

López-Martínez, J., Serrano, E., 2002. Geomorphology of Deception Island. En: López-Martínez J, Smellie JL, Thomson JW, Thomson MRA. Geology and Geomorphology of Deception Island. British Antarctic Survey, Cambridge, UK. BAS Geomap Series, Sheets 6-A, 6-B.

López-Martínez, J., Serrano, E., Schmid, T., Mink, S., Linés, C., 2012. Periglacial processes and landforms in the South Shetland Islands (northern Antarctic Peninsula region). Geomorphology 155-156: 62-79. DOI:10.1016/j.geomorph.2011.12.018.

Lundqvist, J., Lilliesköld, M., Östmark, K., 1995. Glacial and periglacial deposits of the Tumbledown Cliffs area, James Ross Island, West Antarctica. Geomorphology 11, 205-214.

Marrero, S.M., Andrew, S.H., Naylor, M., Attal, M., Shanks, R., Winter, K., Woodward, J., Dunning, S., Westoby, M., Sudgen, D., 2018. Controls on subaerial erosion rates in Antarctica. Earth and Planetary Science Letters 501, 56-66. https://doi.org/10.1016/j.eps1.2018.08.018

McColl, S.T., 2012. Paraglacial rock-slope stability. Geomorphology 153, 1-16. https://doi.org/10.1016/j.geomorph.2012.02.015.

Mercier, D., 2008. Paraglacial geomorphology: Conceptual and methodological revival. Géomorphologie: relief, processus, environnement 4, 219-222. https://doi.org/10.4000/geomorphologie.7395.

Mercier, D., Etienne, S., 2008. Paraglacial geomorphology: processes and paraglacial context. Geomorphology 95, 1-2. https://doi.org/10.1016/S0277-3791(02)00005-7.

Mercier, D., Etienne, S., Sellier, D., André, M.F., 2009. Paraglacial gullying of sediment-mantled slopes: a case study of Colletthøgda, Kongsfjorden area, West Spitsbergen (Svalbard), Earth Surf. Process. Landf. 34, 1772-1789. https://doi.org/10.1002/esp.1862.

Mercier, D., Laffly, D., 2005. Actual paraglacial progradation of the coastal zone in the Kongsfjorden area, western Spitsbergen (Svalbard). Geol. Soc. Lond. Spec. Publ. 242, 111-117. https://doi.org/10.1016/j.geomorph.2011.12.018.

Michalchuk, B.R., Anderson, J.B., Wellner, J.S., Manley, P.L., Majewski, W., Bohaty, S., 2009. Holocene climate and glacial history of the northeastern Antarctic Peninsula: the marine sedimentary record from a long SHALDRIL core. Quat. Sci. Rev. 28, 3049-3065. https://doi.org/10.1016/j.quascirev.2009.08.012

Michel, R.F., Schaefer, C.E., Dias, L., Simas, F.N., Benites, V., Mendonça, E.S., 2006. Ornithogenic Gelisols Cryosols from Maritime Antarctica: Pedogenesis, vegetation and carbon studies. Soil Sci. Soc. Am. J. 70, 1370-1376. https://doi.org/10.2136/sssaj2005.0178

Michel, R.F., Schaefer, C.E., López-Martínez, J., Simas, F.N., Haus, N.W., Serrano, E., Bockheim, J.G., 2014. Soils and landforms from Fildes Peninsula and Ardley Island, Maritime Antarctica. Geomorphology 225, 76-86. https://doi.org/10.1016/j.geomorph.2014.03.041.

Milliken, K.T., Anderson, J.B., Wellner, J.S., Bohaty, S.M., Manley, P.L., 2009. High-resolution Holocene climate record from Maxwell Bay, South Shetland Islands, Antarctica. Geol. Soc. Am. Bull. 121, 1711-1725. https://doi.org/10.1130/B26478.1. 
Mink, S., López-Martínez, J., Maestro, A., Garrote, J., Ortega, J.A., Serrano, E., Durá, J.J., Schmid, T., 2014. Insights into deglaciation of the largest ice-free area in the South Shetland Islands (Antarctica) from quantitative analysis of the drainage system. Geomorphology 225, 4-24. https://doi.org/10.1016/j.geomorph.2014.03.028.

Minzoni, R.T., Anderson, J.B., Fernandez, R., Wellner, J.S., 2015. Marine record of Holocene climate, ocean, and cryosphere interactions: Herbert Sound, James Ross Island, Antarctica. Quat. Sci. Rev. 129, 239-259. https://doi.org/10.1016/j.quascirev.2015.09.009.

Mlčoch, B., Nývlt, D., Mixa, P., 2018. Geological map of James Ross Island - Northern Part 1: 25,000. Czech Geological Survey, Prague.

Monien, P., Schnetger, B., Brumsack, H.J., Hass, H.C., Kuhn, G., 2011. A geochemical record of late Holocene palaeoenvironmental changes at King George Island (Maritime Antarctica). Antarct. Sci. 23, 255-267. https://doi.org/10.1017/S095410201100006X.

Moreau, M., Mercier D., Laffly D. \& Roussel E. (2008). Recent paraglacial dynamics impact on plant colonization: a case study on Midre Lovénbreen foreland, Spitsbergen (Svalbard), Geomorphology, 95(1-2), 48-60. https://doi.org/10.1016/j.geomorph.2006.07.031.

Moreno, L., Silva-Busso, A., López-Martínez, J., Durán, J.J., Martínez-Navarrete, C., Cuchí, J.A., Ermolin, E., 2012. Hydrogeological characteristics at Cape Lamb, Vega Island, Antarctic Peninsula. Antarct. Sci.24, 591-607. https://doi.org/10.1017/S0954102012000478.

Moura, P.A., Francelino, M.R., Schaefer, C.E., Simas, F.N., de Mendonça, B., 2012. Distribution and characterization of soils and landform relationships in Byers Peninsula, Livingston Island, Maritime Antarctica. $\quad$ Geomorphology 45 155, https://doi.org/10.1016/j.geomorph.2011.12.011.

Mulvaney, R., Abram, N.J., Hindmarsh, R.C.A., Arrowsmith, C., Fleet, L., Triest, J., Sime, L., Alemany, O., Foord, S., 2012. Recent Antarctic Peninsula warming relative to Holocene climate and ice shelf history. Nature 488, 141-144. https://doi.org/10.1038/nature11391.

Myrcha, A., Tatur, A., 1991. Ecological role of the current and abandoned penguin rookeries in the land environment of the maritime Antarctic. Pol. Polar Res. 121, 3-24.

Naish, T., Powell, R., Levy, R., Wilson, G., Scherer, R., Talarico, F., Krissek, L., Niessen, F., Pompilio, M., Wilson, T., Carter, L., DeConto, R., Huybers, P., McKay, R., Pollard, D., Ross, J., Winter, D., Barrett, P., Browne, G., Cody, R., Cowan, E., Crampton, J., Dunbar, G., Dunbar, N., Florindo, F., Gebhardt, C., Graham, I., Hannah, M., Hansaraj, D., Harwood, D., Helling, D., Henrys, S., Hinnov, L., Kuhn, G., Kyle, P., Läufer, A., Maffioli, P., Magens, D., Mandernack, K., McIntosh, W., Millan, C., Morin, R., Ohneiser, C., Paulsen, T., Persico, D., Raine, I., Reed, J., Riesselman, C., Sagnotti, L., Schmitt, D., Sjunneskog, C., Strong, P., Taviani, M., Vogel, S., Wilch, T., Williams, T., 2009. Obliquity-paced Pliocene West Antarctic ice sheet oscillations. Nature 458, 322-8. https://doi.org/10.1038/nature07867.

Navarro, F., Jonsell, U., Corcuera, M.I., Martín Español, A., 2013. Decelerated mass loss of Hurd and Johnsons glaciers, Livingston Island, Antarctic Peninsula. J. Glaciol. 59, 115-128.

Navas, A., López-Martínez, J., Casas, J., Machín, J., Durán, J.J., Serrano, E., Cuchí, J.A., Mink, S., 2008. Soil characteristics on varying lithological substrates in the South Shetland Islands, Maritime Antarctica. Geoderma 144, 123-139. https://doi.org/10.1016/j.geoderma.2007.10.011.

Navas, A., López-Martínez, J., Casas, J., Machín, J., Serrano, E., Durán, J.J., Cuchí, J.A., 2006. Soil characteristics along a transect on raised marine surfaces on Byers Peninsula, South Shetland Islands, in: Fütterer, D.K., Damaske, D., Kleinschmidt, G., Miller, H., Tessensohn, F. (Eds.), Antarctica. Contributions to Global Earth Science, Springer.Berlin-Heildelberg-New York, pp. 467-474. https://doi.org/10.1007/3-540-32934-x_60.

Navas, A., Oliva, M., Ruiz-Fernández, J., Gaspar, L., Quijano, L., Lizaga, I., 2017. Radionuclides and soil properties as indicators of glacier retreat in a recently deglaciated permafrost environment of the Maritime Antarctica. Sci. Total Environ. 609, 192-204. https://doi.org/10.1016/j.scitotenv.2017.07.115.

Nedbalová, L., Nývlt, D., Lirio, J.M., Kavan, J., Elster, J., 2017. Current distribution of Branchinecta gaini on James Ross Island and Vega Island. Antarct. Sci. 29, 341-342. https://doi.org/10.1017/S0954102017000128. 
Nedbalová, L., Nývlt, D., Kopáček, J., Šobr, M., Elster, J., 2013. Freshwater lakes of Ulu Peninsula, James Ross Island, northeast Antarctic Peninsula: origin, geomorphology and physical and chemical limnology. Antarct. Sci. 25, 358-372. https://doi.org/10.1017/S0954102012000934.

Negrete, J., Soibelzon, E., Tonni, E.P., Carlini, A., Soibelzon, L.H., Poljak, S., Huarte, R.A., Carbonari, J.E., 2011. Antarctic radiocarbon reservoir: the case of the mummified crabeater seals (Lobodon carcinophaga) in Bodman Cape, Seymour Island, Antarctica. Radiocarbon 53, 161-166. https://doi.org/10.1017/S0033822200034433.

Negrete, J., Soibelzon, L.H., Soibelzon, E., Márquez, M.E.I., Loza, C.M., Acosta, W., Lusky, J., Pecoraro, M., 2015. Aggregation of mummified adult crabeater seals (Pinnipedia: Phocidae) in the eastern Antarctic Peninsula: age and sex structure, taphonomy and cause of death. Antarct. Sci. 27, 274-280. https://doi.org/10.1017/S0954102014000741.

Nelson, A.E., Smellie, J.L., Williams, M., Moreton, S., 2008. Age, geographical distribution and taphonomy of an unusual occurrence of mummified crabeater seals on James Ross Island, Antarctic Peninsula. Antarct. Sci. 20, 485-493. https://doi.org/10.1017/S095410200800134X.

Newsham, K.K., Pearce, D.A., Bridge, P.D., 2010. Minimal influence of water and nutrient content on the bacterial community composition of a maritime Antarctic soil. Microbiol. Res. 165, 523-530. https://doi.org/10.1016/j.micres.2009.11.005.

Nield, G.A., Barletta, V.R., Bordoni, A., King, M.A., Whitehouse, P.L., Clarke, P.J., Domack, E., Scambos, T.A., Berthier, E., 2014. Rapid bedrock uplift in the Antarctic Peninsula explained by viscoelastic response to recent ice unloading. Earth Planet. Sci. Lett. 397, 32-41. https://doi.org/10.1016/j.eps1.2014.04.019.

Nozal, F., Martin-Serrano, A., Montes, M., Del Valle, R., 2013. Mapa geomorfológico de Bahía Esperanza. Antártica; scale 1:10,000. 1st edition. Serie Cartográfica Geocientifica Antártica. Madrid: Instituto Geológicao y Minero de España, Buenos Aires: Instituto Antártico Argentino.

Nývlt, D., Braucher, R., Engel, Z., Mlčoch, B., ASTER Team, 2014. Timing of the Northern Prince Gustav Ice Stream retreat and the deglaciation of northern James Ross Island, Antarctic Peninsula during the last glacial-interglacial transition. Quat. Res. 82, 441-449. https://doi.org/10.1016/j.yqres.2014.05.003.

Nývlt, D., Košler, J., Mlčoch, B., Mixa, P., Lisá, L., Bubík, M., Hendriks, B.W.H., 2011. The Mendel Formation: Evidence for Late Miocene climatic cyclicity at the northern tip of the Antarctic Peninsula. Palaeogeogr. Palaeoclimatol. Palaeoecol. 299, 363-384. https://doi.org/10.1016/j.palaeo.2010.11.017.

Nývlt, D., Nývltová, Fišáková, M., Barták, M., Stachoň, Z., Pavel, V., Mlčoch, B., Láska, K., 2016. Death age, seasonality, taphonomy and colonization of seal carcasses from Ulu Peninsula, James Ross Island, Antarctic Peninsula. Antarct. Sci. 28, 3-16. https://doi.org/10.1017/S095410201500036X.

Ó Cofaigh, C., Davies, B.J., Livingstone, S.J., Smith, J.A., Johnson, J.S., Hocking, E.P., Hodgson, D.A., Anderson, J.B., Bentley, M.J., Canals, M., Domack, E., Dowdeswell, J.A., Evans, J., Glasser, N.F., Hillenbrand, C.D., Larter, R.D., Roberts, S.J., Simms, A.R., 2014. Reconstruction of icesheet changes in the Antarctic Peninsula since the Last Glacial Maximum. Quat. Sci. Rev. 100, 87-110. https://doi.org/10.1016/j.quascirev.2014.06.023.

Oliva, M., Antoniades, D., Giralt, S., Granados, I., Pla-Rabes, S., Toro, M., Liu, E.J., Sanjurjo, J., Vieira, G. 2016. The Holocene deglaciation of the Byers Peninsula (Livingston Island, Antarctica) based on the dating of lake sedimentary records. Geomorphology 261, 89-102. https://doi.org/10.1016/j.geomorph.2016.02.029.

Oliva, M., Hrbacek, F., Ruiz-Fernández, J., de Pablo, M.A., Vieira, G., Ramos, M., Antoniades, D., 2017b. Active layer dynamics in three topographically distinct lake catchments in Byers Peninsula (Livingston Island, Antarctica). Catena 149, 548-559. http://dx.doi.org/10.1016/j.catena.2016.07.011

Oliva, M., Mercier, D., Ruiz-Fernández, J., McColl, S., 2019. Paraglacial processes in recently deglaciated environments. Land Degrad Dev. https://doi.org/10.1002/ldr.3283

Oliva, M., Navarro, F., Hrbáček, F., Hernandéz, A., Nývlt, D., Perreira, P., Ruiz-Fernández, J., Trigo, R., 2017a. Recent regional climate cooling on the Antarctic Peninsula and associated impacts on the cryosphere. Sci. Total Environ. 580, 210-223. https://doi.org/10.1016/j.scitotenv.2016.12.030. 
Oliva, M., Ruiz-Fernández, J., 2015. Coupling patterns between para-glacial and permafrost degradation responses in Antarctica. Earth Surf. Process. Landf. 40, 1227-1238. https://doi.org/10.1002/esp.3716.

Oliva, M., Ruiz-Fernández, J., 2017. Geomorphological processes and frozen ground conditions in Elephant Point (Livingston Island, South Shetland Islands, Antarctica). Geomorphology 293, 368-379. https://doi.org/10.1016/j.geomorph.2016.01.020.

Owen, L.A., Sharma, M.C., 1998. Rates and magnitudes of paraglacial fan formation in the Garhwal Himalaya: implications for landscape evolution. Geomorphology 26, 171-184. https://doi.org/10.1016/S0169-555X(98)00057-9.

Palacios, D., Parrilla, G., Zamorano, J.J., 1999. Paraglacial and postglacial debris flows on a Little Ice Age terminal moraine: Jamapa Glacier, Pico de Orizaba (Mexico). Geomorphology 28, 95-118.

Pereira, T.T., Schaefer, C.E., Ker, J.C., Almeida, C.C., Almeida, I.C., Pereira, A.B., 2013. Genesis, mineralogy and ecological significance of ornithogenic soils from a semi-desert polar landscape at Hope Bay, Antarctic Peninsula. Geoderma 209, 98-109. https://doi.org/10.1016/j.geoderma.2013.06.012.

Píšková, A., Nývlt, D., Roman, M., Lirio, J.M., Kopalová, K., 2017. Revealing past environmental changes on the Antarctic Peninsula by analyzing high resolution sedimentary records from Lake Esmeralda, Vega Island. Geophys. Res. Abstr. 19, 6135.

Pudsey, C.J., Evans, J., 2001. First survey of Antarctic sub-ice shelf sediments reveals mid-Holocene ice shelf retreat. Geology 29, 787-790. https://doi.org/10.1130/00917613(2001)029<0787: FSOASI $>2.0 . \mathrm{CO} ; 2$.

Pudsey, C.J., Murray, J.W., Appleby, P., Evans, J., 2006. Ice shelf history from petrographic and foraminiferal evidence, Northeast Antarctic Peninsula. Quat. Sci. Rev. 25, 2357-2379. https://doi.org/10.1016/j.quascirev.2006.01.029.

Rachlewicz, G., 2010. Paraglacial modifications of glacial sediments over millennial to decadal timescales in the High Artic (Billefjorden, Central Spitsbergen, Svalbard). Quaestiones Geographicae 29, 59-67. https://doi.org/10.2478/v10117-010-0023-4.

Radic, V., Bliss, A., Beedlow, A.C., Hork, R., Miles, E., Cogley, J.G., 2014. Regional and global projections of twenty-first century glacier mass changes in response to climate scenarios from global climate models. Clim. Dyn. 42, 37-58. https://doi.org/10.1007/s00382-013-1719-7.

Raymo, M.E., Lisiecki, L.E., Nisancioglu, K.H., 2006. Plio-Pleistocene Ice Volume, Antarctic Climate, and the Global $\delta 18 \mathrm{O}$ Record. Science 313, 492-495. https://doi.org/10.1126/science.1123296.

Riquelme, R., Rojas, C., Aguilar, G., Flores, P., 2011. Late Pleistocene-early Holocene paraglacial and fluvial sediment history in the Turbio valley, semiarid Chilean Andes. Quat. Res. 75, 166-175. https://doi.org/10.1016/j.yqres.2010.10.001.

Roberts, S.J., Hodgson, D.A., Bentley, M.J., Sanderson, D.C.W., Milne, G., Smith, J.A., Verleyen, E., Balbo, A., 2009. Holocene relative sea-level change and deglaciation on Alexander Island, Antarctic Peninsula, from elevated lake deltas. Geomorphology 112, 122-134. https://doi.org/10.1016/j.geomorph.2009.05.011.

Roberts, S.J., Hodgson, D.A., Bentley, M.J., Smith, J.A., Millar, I.L., Olive, V., Sugden, D.E., 2008. The Holocene history of George VI Ice Shelf, Antarctic Peninsula from clast-provenance analysis of epishelf lake sediments. Palaeogeogr. Palaeoclimatol. Palaeoecol. 259, 258-283. https://doi.org/10.1016/j.palaeo.2007.10.010.

Roberts, S.R., Sterken, M., Hodgson, D.A., Vyverman, W., Balbo, A.L., Sabbe, K., Moreton, S.G., Verleyen, E., 2011. Geological constraints on glacio-isostatic adjustment models of relative sealevel change during deglaciation of Prince Gustav Channel, Antarctic Peninsula. Quat. Sci. Rev. 30, 3603-3617. https://doi.org/10.1016/j.quascirev.2011.09.009.

Roman, M., Nedbalová, L., Kohler, T.J., Lirio, J.M., Coria, S.H., Kopáček, J., Vignoni, P., Kopalová, K., Lecomte, K., Elster, J., Nývlt, D. Lacustrine systems of Clearwater Mesa (James Ross Island, northeastern Antarctic Peninsula): geomorphological settings and limnological characterization. Submitted for publication in Antarct. Sci.

Royles, J., Amesbury, M.J., Convey, P., Griffiths, H., Hodgson, D.A., Leng, M.J., Charman, D.J., 2013. Plants and Soil Microbes Respond to Recent Warming on the Antarctic Peninsula. Curr. Biol. 23, 1702-1706. https://doi.org/10.1016/j.cub.2013.07.011. 
Royles, J., Meogèe, J., Wingate, L., Hodgson, D.A., Convey, P., Griffiths, H., 2012. Carbon isotope evidence for recent climate-related enhancement of $\mathrm{CO} 2$ assimilation and peat accumulation rates in Antarctica. Glob. Chang. Biol. 18, 3112-3124. https://doi.org/10.1111/j.13652486.2012.02750.x.

Rückamp, M., Braun, M., Suckro, S., Blindow, N., 2011. Observed glacial changes on the King George Island ice cap, Antarctica, in the last decade. Glob. Planet. Chang. 79, 99-109. https://doi.org/10.1016/j.gloplacha.2011.06.009.

Ruiz-Fernández, J., Oliva, M., 2016. Relative palaeoenvironmental adjustments following deglaciation of the Byers Peninsula (Livingstone Island, Antarctica). Arct. Antarct. Alp. Res. 48, 345-359. https://doi.org/10.1657/AAAR0015-014.

Ruiz-Fernández, J., Oliva, M., García-Hernández, C., 2016. Procesos geomorfológicos y formas del relieve en dos cuencas lacustres de la península Byers (isla Livingston, Antártida marítima): implicaciones paleoambientales. Polígonos. Revista de Geografía, 28, 211-237. https://doi.org/10.18002/pol.v0i28.4294.

Ruiz-Fernández, J., Oliva, M., García-Hernández, C., 2017. Topographic and geomorphologic controls on the distribution of vegetation formations in Elephant Point (Livingston Island, Maritime $\begin{array}{llll}\text { Antarctica). } & \text { Sci. } & \text { Total } & \text { 340-349. }\end{array}$ https://doi.org/10.1016/j.scitotenv.2017.02.158.

Sancho, L.G., Pintado, A., 2004. Evidence of high annual growth rate for lichens in the Maritime Antarctic. Polar Biol. 27, 312-319. https://doi.org/10.1007/s00300-004-0594-4.

Sancho, L.G., Valladares, F., 1993. Lichen colonization of recent moraine on Livingston Island (South Shetland I, Antarctica). Polar Biol. 13, 227-233.

Schaefer, C.E., Pereira, C., Torres, T., Ker, J.C., Almeida, I.C., Simas, F.N., Vieira, G., 2015. Soils and Landforms at Hope Bay, Antarctic Peninsula: Formation, Classification, Distribution, and Relationships. Soil Sci. Soc. Am. J. 79, 175-184. https://doi.org/10.2136/sssaj2014.06.0266.

Schlensog, M., Green, T.A., Schroeter, B., 2013. Life form and water source interact to determine active time and environment in cryptogams: an example from the maritime Antarctic. Oecologia 173, 59-72. https://doi.org/10.1007/s00442-013-2608-9.

Seehaus, T., Cook, A.J., Silva, A.B., Braun, M., 2018. Changes in glacier dynamics in the northern Antarctic Peninsula since 1985. Cryosphere, 12, 577-594. https://doi.org/10.5194/tc-12-5772018.

Seong, Y.B., Owen, L.A., Lim, H.S., Yoon, H.I., Kim, Y., Lee, Y.I., Caffee, M.W., 2009. Rate of late Quaternary ice-cap thinning on King George Island, South Shetland Islands, West Antarctica defined by Cosmogenic $36 \mathrm{Cl}$ surface exposure dating. Boreas 38, 207-213. https://doi.org/10.1111/j.1502-3885.2008.00069.x.

Serrano, E., Giner, J., Gumiel, P., López-Martínez, J., 2004. El glaciar rocoso de Hurd. Estructura e inserción en el sistema de transferencia de derrubios antártico marítimo (Isla Livingston, Islas Shetland del Sur, Antarctica). Cuaternario y Geomorfología 18, 13-24.

Serrano, E., Gumiel, P., Giner, J., López-Martínez, J., 2002. Morfodinámica de laderas en las Islas Shetland del Sur (Antártida marítima), in: Serrano, E., García, A. (Eds.), Periglaciarismo en montaña y altas latitudes. Dpto. Geografía, Universidad de Valladolid, Valladolid, pp. 231-256.

Serrano, E., López-Martínez, J., 1997a. Evolución de las formas de relieve y los depósitos superficiales cuaternarios en la Isla Media Luna. Islas Shetland del Sur. Bol. R. Soc. Esp. Hist. Nat. (Sección Geológica), 93, 207-218.

Serrano, E., López-Martínez, J., 1997b. Geomorfología de la Península Coppermine, Isla Robert, islas Shetland del Sur, Antártida. Serie Científica INACH, 47, 19-29.

Serrano, E., López-Martínez, J., 1998. Caracterización y distribución de las formas y los procesos periglaciares en las Islas Shetland del Sur (Antártida), in: Gómez, A., Salvador, F., Schulte, L., García, A. (Eds.), Procesos biofísicos actuales en medios fríos. Estudios recientes. Universidad de Barcelona, Barcelona, pp. 181-204.

Serrano, E., López-Martínez, J., 2000. Rock glaciers in the South Shetland Islands, Western Antarctica. Geomorphology 35, 145-162. https://doi.org/10.1016/S0169-555X(00)00034-9.

Serrano, E., López-Martínez, J., 2004. Morfogénesis periglaciar y deglaciación en las penínsulas Barton y Weaver (Islas Shetland del Sur, Antártida). Bol. R. Soc. Esp. Hist. Nat. (Sección Geológica), 99, 131-140. 
Serrano, E., Martínez de Pisón, E., López-Martínez, J., 1996. Periglacial and nival landforms and deposits, in: López-Martínez, J., Thomson, M.R.A., Thomson, J.W. (Eds.), Geomorphological Map of Byers Peninsula, Livingston Island. British Antarctic Survey, Cambridge, UK. BAS Geomap Series, Sheet 5-A, pp. 28-34.

Shevenell, A.E., Ingalls, A.E., Domack, E.W., Kelly, C., 2011. Holocene Southern Ocean surface temperature variability west of the Antarctic Peninsula. Nature 470, 250-254. https://doi.org/10.1038/nature09751.

Siegert, M.J., Barrett, P., DeConto, R., Dunbar, R., Ó Cofaigh, C., Passchier, S., Naish, T., 2008. Recent advances in understanding Antarctic climate evolution. Antarct. Sci. 20, 313-325. https://doi.org/10.1017/S0954102008000941.

Simas, F.N., Schaefer, C.E., Melo, V.F., Albuquerque-Filho, M.R., Michel, R.F., Pereira, V.V., Gomes, M.R., da Costa, L.M., 2007. Ornithogenic cryosols from Maritime Antarctica: phosphatization as a soil forming process. Geoderma 138, 191-203. https://doi.org/10.1016/j.geoderma.2006.11.011.

Simms, A.R., DeWitt, R., Kouremenos, P., Drewry, A.M., 2011. A new approach to reconstructing sea levels in Antarctica using optically stimulated luminescence of cobble surfaces. Quat. Geochronol. 6, 50-60. https://doi.org/10.1016/j.quageo.2010.06.004.

Simms, A.R., Ivins, E., DeWitt, R., Kouremenos, P., Simkins, L.M., 2012. Timing of the most recent Neoglacial advance and retreat in the South Shetland Islands, Antarctic Peninsula: insights from raised beaches and Holocene uplift rates. Quat. Sci. Rev. 47, 41-55.

Simms, A.R., Milliken, K.T., Anderson, J.B., Wellner, J.S., 2011. The marine record of deglaciation of the South Shetland Islands, Antarctica since the Last Glacial Maximum. Quat. Sci. Rev. 30, 1583-1601. https://doi.org/10.1016/j.quascirev.2011.03.018.

Skvarca, P., Rott, H., Nagler, T., 1995. Satellite imagery, a base line for glacier variation study on James Ross Island, Antarctica. Ann. Glaciol. 21, 291-296. https://doi.org/10.3189/S0260305500015962.

Smellie, J.L., Johnson, J.S., Nelson, A.E., 2013. Geological Map of James Ross Island 1. James Ross Island Volcanic Group (1:125000 scale). BAS Geomap 2 Series, Sheet 5. https://doi.org/10.1029/2006GC001450.20.

Smith, R.I.L., 1982. Plant succession and re-exposed moss banks on a deglaciated headland in Arthur Harbour, Anvers Island. Br. Antarct. Surv. Bull. 51, 193-199.

Smith, R.I.L., 1984. Terrestrial plant biology of the sub-Antarctic and Antarctic, in: Laws, R.M. (Ed.), Antarctic ecology. Academic Press, London, pp. 61-162.

Smith, R.I.L., 1995. Colonization by lichens and the development of lichen dominated communities in the Maritime Antarctic. The Lichenologist 27, 473-483. https://doi.org/10.1016/S00242829(05)80007-6

Smith, R.T., Anderson, J.B., 2010. Ice-sheet evolution in James Ross Basin, Weddell sea margin of the Antarctic peninsula: The seismic stratigraphic record. Geol. Soc. Am. Bull. 122, 830-842. https://doi.org/10.1130/B26486.1.

Smith, R.C., Ainley, D., Baker, K., Domack, E., Emslie, S., Fraser, B., Kennett, J., Leventer, A., Mosley-Thompson, E., Stammerjohn, S., Vernet, M., 1999. Marine ecosystem sensitivity to climate change. Bioscience 49, 393-404.

Smykla, J., Wołek, J., Barcikowski, A., 2007. Zonation of vegetation related to penguin rookeries on King George Island, Maritime Antarctic. Arct. Antarct. Alp. Res. 39, 143-151. https://doi.org/10.1657/1523-0430(2007)39[143:ZOVRTP]2.0.CO;2.

Smykla, J., Wołek, J., Barcikowski, A., Loro, P., 2006. Vegetation patterns around penguin rookeries at Admiralty Bay, King George Island, maritime Antarctic: preliminary results. Polish Bot. Stud. 22, 449-458.

Sone, T., Fukui, K., Strelin, J.A., Torielli, C.A., Mori, J., 2007. Glacier lake outburst flood on James Ross Island, Antarctic Peninsula region. Pol. Polar Res. 28, 3-12. https://doi.org/10.1.1.616.6101.

Souza, K.K., Schaefer, C.E., Simas, F.N., Spinola, D.N., de Paula, M.D., 2014. Soil formation in Seymour Island, Weddell Sea, Antarctica. Geomorphology 225, 87-99. https://doi.org/10.1016/j.geomorph.2014.03.047. 
Sterken, M., Roberts, S.J., Hodgson, D.A., Vyverman, W., Balbo, A.L., Sabbe, K., Moreton, S.G., Verleyen, E., 2012. Holocene glacial and climate history of Prince Gustav Channel, northeastern Antarctic Peninsula. Quat. Sci. Rev. 31, 93-111. https://doi.org/10.1016/j.quascirev.2011.10.017.

Strauss, S.L., Garcia-Pichel, F., Day, T.A., 2012. Soil microbial carbon and nitrogen transformations at a glacial foreland on Anvers Island, Antarctic Peninsula. Polar Biol. 35, 1459-1471. https://doi.org/10.1007/s00300-012-1184-5.

Strauss, S.L., Ruhland, C.T., Day, T.A., 2009. Trends in soil characteristics along a recently deglaciated foreland on Anvers Island, Antarctic Peninsula. Polar Biol. 32, 1779-1788. https://doi.org/10.1007/s00300-009-0677-3.

Strelin, J.A., Sone, T., 1998. Rock glaciers on James Ross Island, Antarctica. Permafrost. Seventh International Conference (Proceedings), 55, 1027-1033.

Strelin, J.A., Malagnino, E.C., 1992. Geomorfologia de la Isla James Ross, in: Rinaldi, C.A. (Ed.), Geología de la isla James Ross, Instituto Antártico Argentino, Buenos Aires, pp. 7-36.

Strelin, J.A., Torielli, C.A., Sone, T., Fukui, K., Mori, J., 2007. Rerticularidades genéticas de glaciares de roca en la isla James Ross, Península Antártica. Revista de la Asociación Geológica Argentina, 62, 627-634.

Strzelecki, M., Lim, M., Kasprzak, M., Swirad, Z., Rachlewicz, G., Pawlowski, L., Jaskolski, M., Migoń, P., 2017. Impact of periglacial and paraglacial processes on rocky coast geomorphology in Arctic and Antarctic. Geophys. Res. Abstr. 19, 7814.

Tatur, A., 1989. Ornithogenic soils of the maritime Antarctic. Pol. Polar Res. 10, 481-532.

Tatur, A., 2002. Ornithogenic ecosystems in the Maritime Antarctic-Formation, Development and Disintegration, in: Beyer, L., Bölter, M., (Eds.), Geoecology of Antarctic Ice-Free Coastal Landscapes. Springer Verlag, Berlin - Heidelberg, pp, 161-184.

Tatur, A., Barczuk, A., Del Valle, R., Sletten, R., Kicinska, E., 1993. Surface mineralization on Seymour Island, Antarctica. Pol. Polar Res. 14, 153-168.

Tatur, A., Myrcha, A., Niegodzisz, J., 1997. Formation of abandoned penguin rookery ecosystems in the maritime Antarctic. Polar Biol. 17, 405-417. https://doi.org/10.1007/s003000050135.

Toro, M., Granados, I., Pla, S., Giralt, S., Antoniades, D., Galán, L., Cortizas, A.M., Lim, H.S., Appleby, P.G., 2013. Chronostratigraphy of the sedimentary record of Limnopolar Lake, Byers Peninsula, Livingston Island, Antarctica. Antarct. Sci. 25, 198-212. https://doi.org/10.1017/S0954102012000788.

Toro, M., Camacho, A., Rochera, C., Rico, E., Bañó, M., Fernández-Valiente, E., Marco, E., Justel, A., Avendano, M.C., Ariosa, Y., Vincent, W.F., Quesada, A., 2007. Limnological characteristics of freshwater ecosystems of Byers Peninsula, Livingston Island, in Maritime Antarctica. Polar Biol. 30, 635-649. DOI 10.1007/s00300-006-0223-5.

Troedson, A.L., Smellie, J.L., 2002. The Polonez Cove Formation of King George Island, Antarctica: Stratigraphy, facies and implications for mid-Cenozoic cryosphere development. Sedimentology 49, 277-301. https://doi.org/10.1046/j.1365-3091.2002.00441.x.

Turner, J., Colwell, S.R., Marshall, G.J., Lachlan-Cope, T.A., Carleton, A.M., Jones, P.D., Lagun, V., Reid, P.A., Lagovkina, S., 2005. Antarctic climate change during last 50 years. Int. J. Climatol. 25, 279-294. https://doi.org/10.1002/joc.1130.

Turner, J., Barrand, N.E., Bracegirdle, T.J., Convey, P., Hodgson, D.A., Jarvis, M., Jenkins, A., Marshall, G., Meredith, M.P., Roscoe, H., Shanklin, J., French, J., Goosse, H., Guglielmin, M., Gutt. J., Jacobs, S., Kennicutt, M.C., Masson-Delmotte, V., Mayewski, P., Navarro, F., Robinson, S., Scambos, T., Sparrow, M., Summerhayes, C., Speer, K., Klepikov, A., 2014. Antarctic climate change and the environment: an update. Polar Rec. 50(3), 237-259. https://doi.org/10.1017/S0032247413000296.

Váczi, P., Barták, M., Nedbalová, L., Elster, J., 2011. Comparative analysis of temperature courses in Antarctic lakes of different morphology: Study from James Ross Island, Antarctica. Czech Polar Rep. 1, 78-87. https://doi.org/10.5817/CPR2011-2-7.

Valladares, F., Sancho, L.G., 1995. Lichen colonization and recolonization of two recently deglaciated zones in the maritime Antarctic. The Lichenologist 27, 485-493. https://doi.org/10.1016/S00242829(05)80008-8. 
Vaughan, D.G., Marshall, G.J., Connolley, W.M., Parkinson, C., Mulvaney, R., Hodgson, D.A., King, J.C., Pudsey, C.J., Turner, J., 2003. Recent rapid regional climate warming on the Antarctic Peninsula. Clim. Chang. 60, 243-274.

Vieira, G., Bockheim, J., Guglielmin, M., Balks, M., Abramov, A.A., Boelhouwers, J., Cannone, N., Ganzert, L., Gilichinsky, D., Goryachkin, S., López-Martínez, J., Meiklejohn, I., Raff,i R., Ramos, M., Schaefer, C., Serrano, E., Simas, F., Sletten, R., Wagner, D. 2010. Thermal state of permafrost and active-layer monitoring in the Antarctic: advances during the International Polar Year 2007-2008. Permafr. Periglac. Process. 21, 182-197. https://doi.org/10.1002/ppp.685.

Watcham, E.P., Bentley, M.J., Hodgson, D.A., Roberts, S.J., Fretwell, P.T., Lloyd, J.M., Larter, R.D., Whitehouse, P.L., Leng, M.J., Monien, P., Moreton, S.G., 2011. A new Holocene relative sea level curve for the South Shetland Islands, Antarctica. Quat. Sci. Rev. 30, 3152-3170. https://doi.org/10.1016/j.quascirev.2011.07.021.

Weaver, A.J., Saenko, O.A., Clark, P.U., Mitrovica, J.X., 2003. Meltwater Pulse 1A from Antarctica as a Trigger of the Bølling-Allerød Warm Interval. Science 299, 1709-1713. https://doi.org/10.1126/science.1081002.

Weber, M.E., Clark, P.U., Kuhn, G., Timmermann, A., Sprenk, D., Gladstone, R., Zhang, X., Lohmann, G., Menviel, L., Chikamoto, M.O., Friedrich, T., Ohlwein, C., 2014. Millennial-scale variability in Antarctic ice-sheet discharge during the last deglaciation. Nature 510, 134-138. https://doi.org/10.1038/nature13397.

Wilhelm, K.R., Bockheim, J.G., Kung, S., 2015. Active layer thickness prediction on the Western Antarctic Peninsula. Permafr. Periglac. Process. 26(2), 188-199. https://doi.org/10.1002/ppp.1845.

Ye, Z., Rongquan, L., 1999. 14C dating of moss peat banks in Fildes Peninsula, Antarctica. Chinese Sci. Bull. 44, 1817-1819. https://doi.org/10.1007/bf02886168.

Yegorova, T., Bakhmutov, V., Janik, T., Grad, M., 2011. Joint geophysical and petrological models for the lithosphere structure of the Antarctic Peninsula continental margin. Geophys. J. Int. 184, 90110. https://doi.org/10.1111/j.1365-246x.2010.04867.x.

Yergeau, E., Kowalchuk, G.A., 2008. Responses of Antarctic soil microbial communities and associated functions to temperature and freeze-thaw cycle frequency. Environ. Microbiol. 109, 2223-2235. https://doi.org/10.1111/j.1462-2920.2008.01644.x.

Yoo, K.C., Yoon, H.I., Kim, J.K., Khim, B.K., 2009. Sedimentological, geochemical and palaeontological evidence for a neoglacial cold event during the late Holocene in the continental shelf of the northern South Shetland Islands, West Antarctica. Polar Res. 28, 177-192. https://doi.org/10.1111/j.1751-8369.2009.00109.x.

Zvěřina, O., Coufalík, P., Brat, K., Červenka, R., Kuta, J., Mikeš, O., Komárek, J., 2017. Leaching of mercury from seal carcasses into Antarctic soils. Environ. Sci. Pollut. Res. 24, 1424-1431. https://doi.org/10.1007/s11356-016-7879-3.

Zwally, H.J., Li, J., Robbins, J.W., Saba, J.L., Yi, D., Brenner, A.C., 2015. Mass gains of the Antarctic ice sheet exceed losses. J. Glaciol. 61, 1019-1036. https://doi.org/10.3189/2015JoG15J071.

\section{Figure captions}

Figure 1. (A) Location map of the AP region within the Antarctic continent, and (B) extension of icefree areas around the AP region.

Figure 2. Detail of the study area including the main sites mentioned in the text.

Figure 3. Examples of the redefinition of coastlines related to past $(A, B, C)$ and recent (D, E, F) paraglacial responses.

Figure 4. Examples of permafrost, periglacial processes and mass movements related to past $(\mathrm{A}, \mathrm{B}, \mathrm{C})$ and recent (D, E, F) paraglacial responses. 
Figure 5. Examples of alluvial and lacustrine dynamics related to past $(\mathrm{A}, \mathrm{B}, \mathrm{C})$ and recent $(\mathrm{D}, \mathrm{E}, \mathrm{F})$ paraglacial responses.

Figure 6. Examples of geoecological processes related to past (A, B, C) and recent (D, E, F) paraglacial responses.

Figure 7. Synthetic representation of past and recent paraglacial responses in the AP region. 


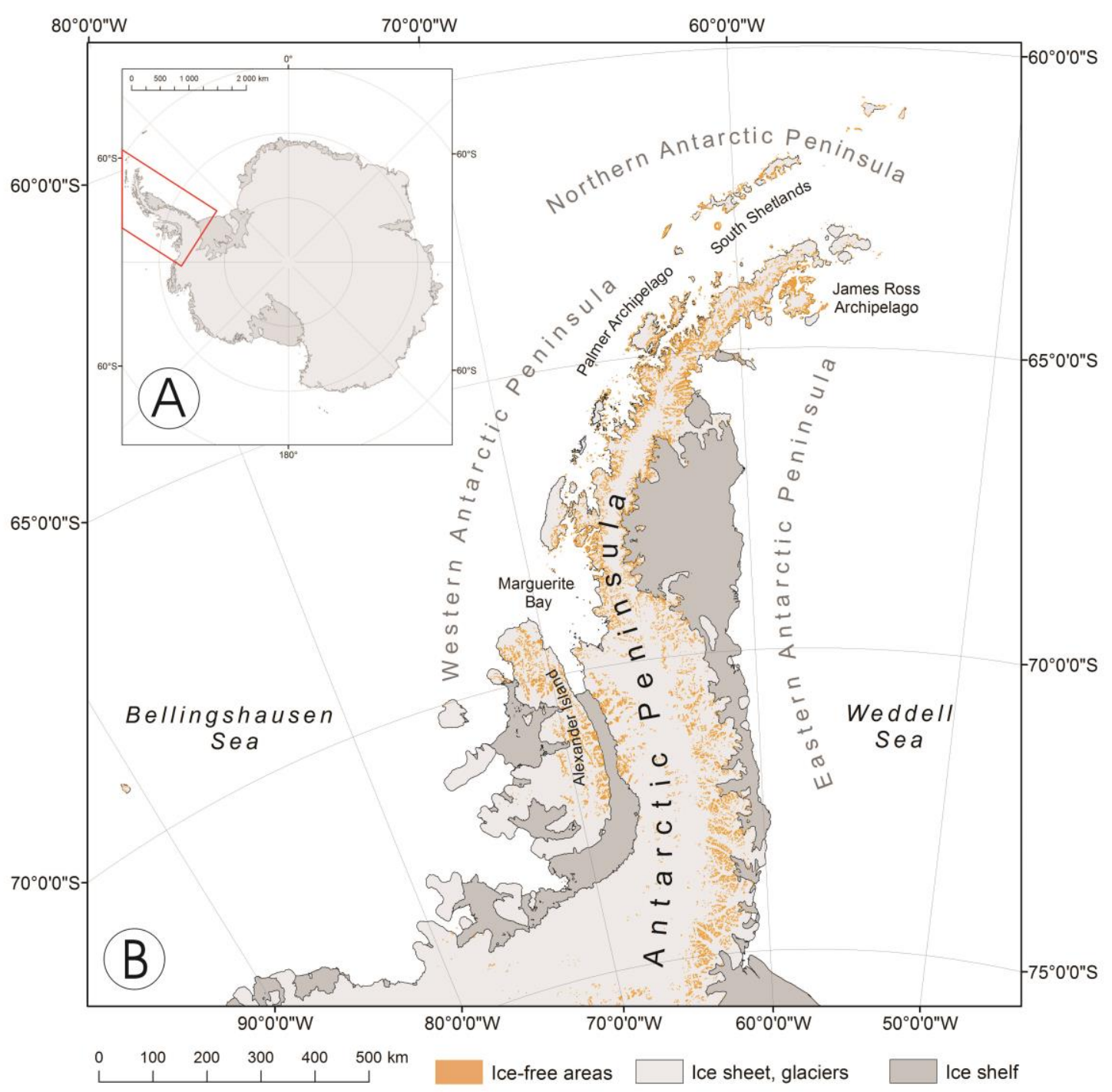

Figure 1. (A) Location map of the AP region within the Antarctic continent, and (B) extension of ice-free areas around the AP region. 


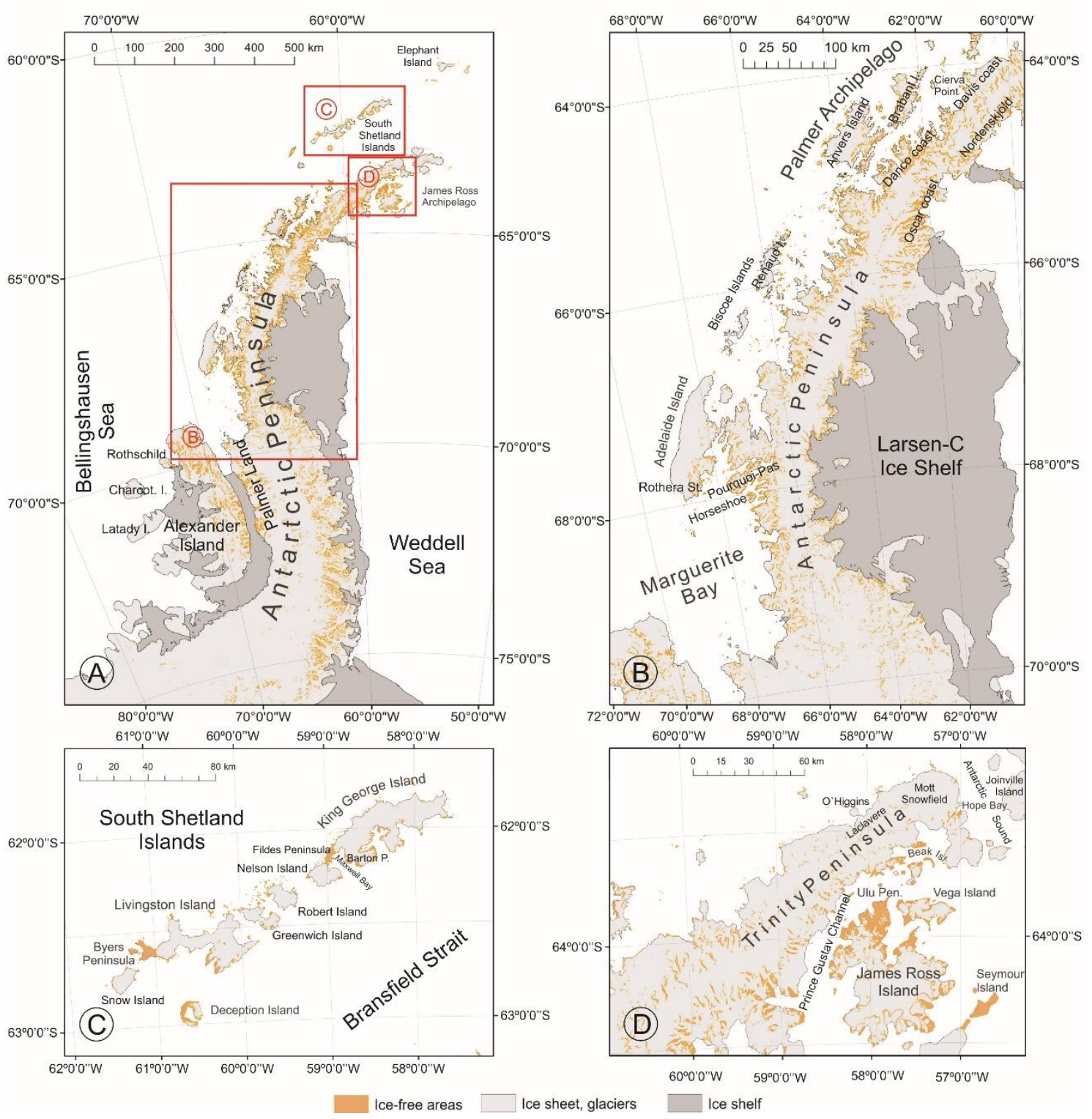

Figure 2. Detail of the study areas including the main sites mentioned in the text. 


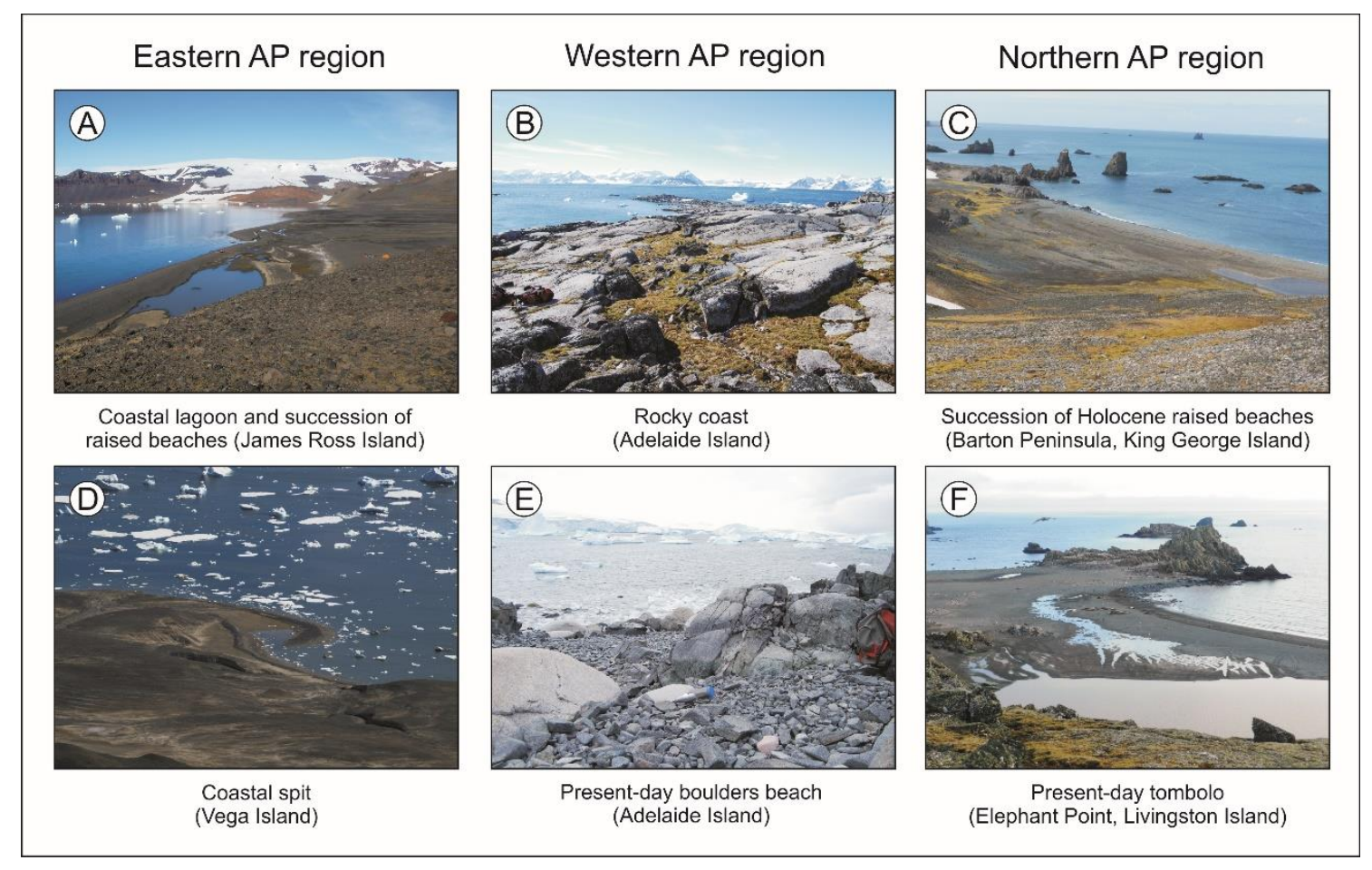

Figure 3. Examples of the redefinition of coastlines related to past (A, B, C) and recent (D, E, F) paraglacial responses.

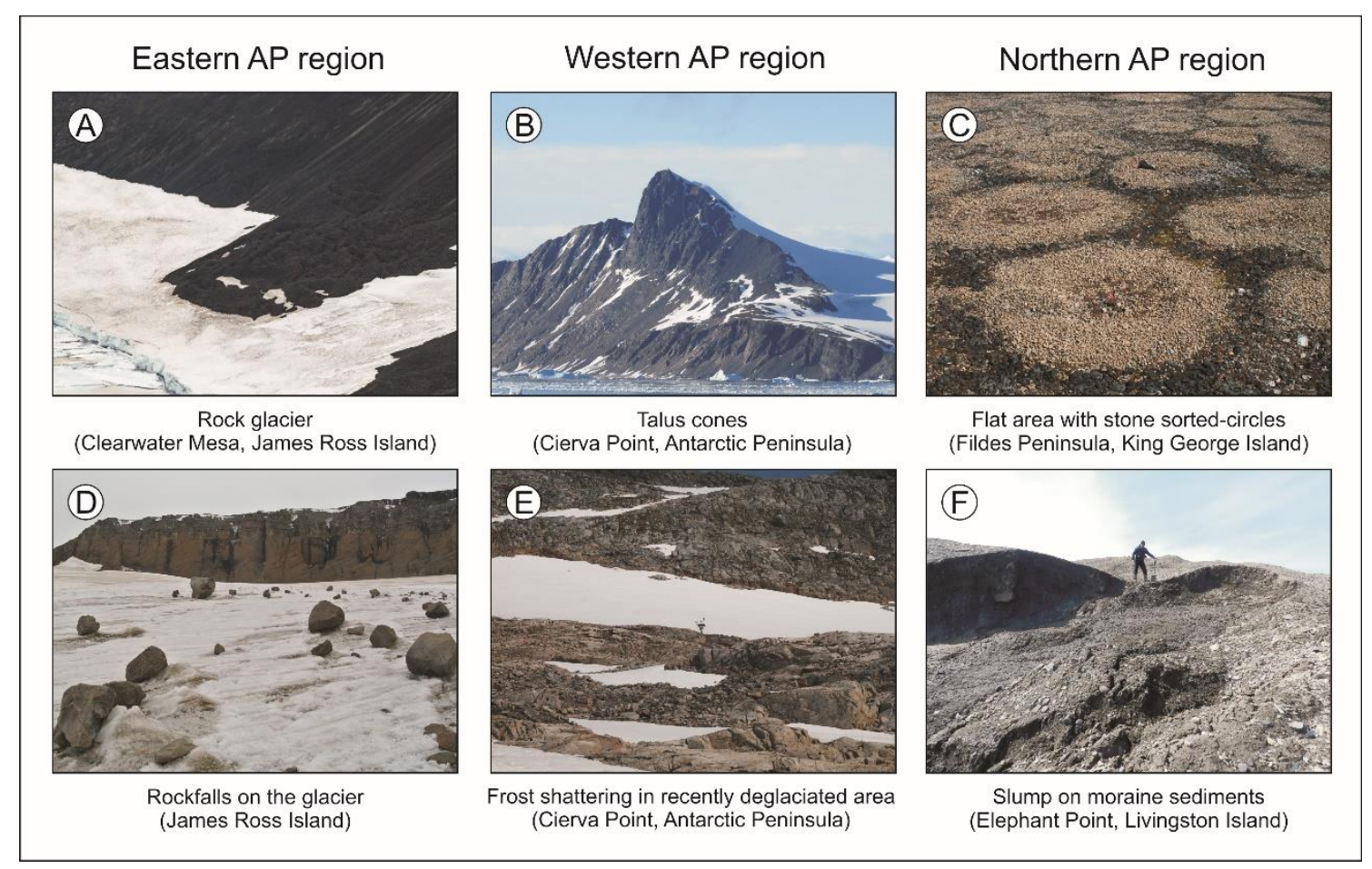

Figure 4. Examples of permafrost, periglacial processes and mass movements related to past (A, $\mathrm{B}, \mathrm{C})$ and recent $(\mathrm{D}, \mathrm{E}, \mathrm{F})$ paraglacial responses. 


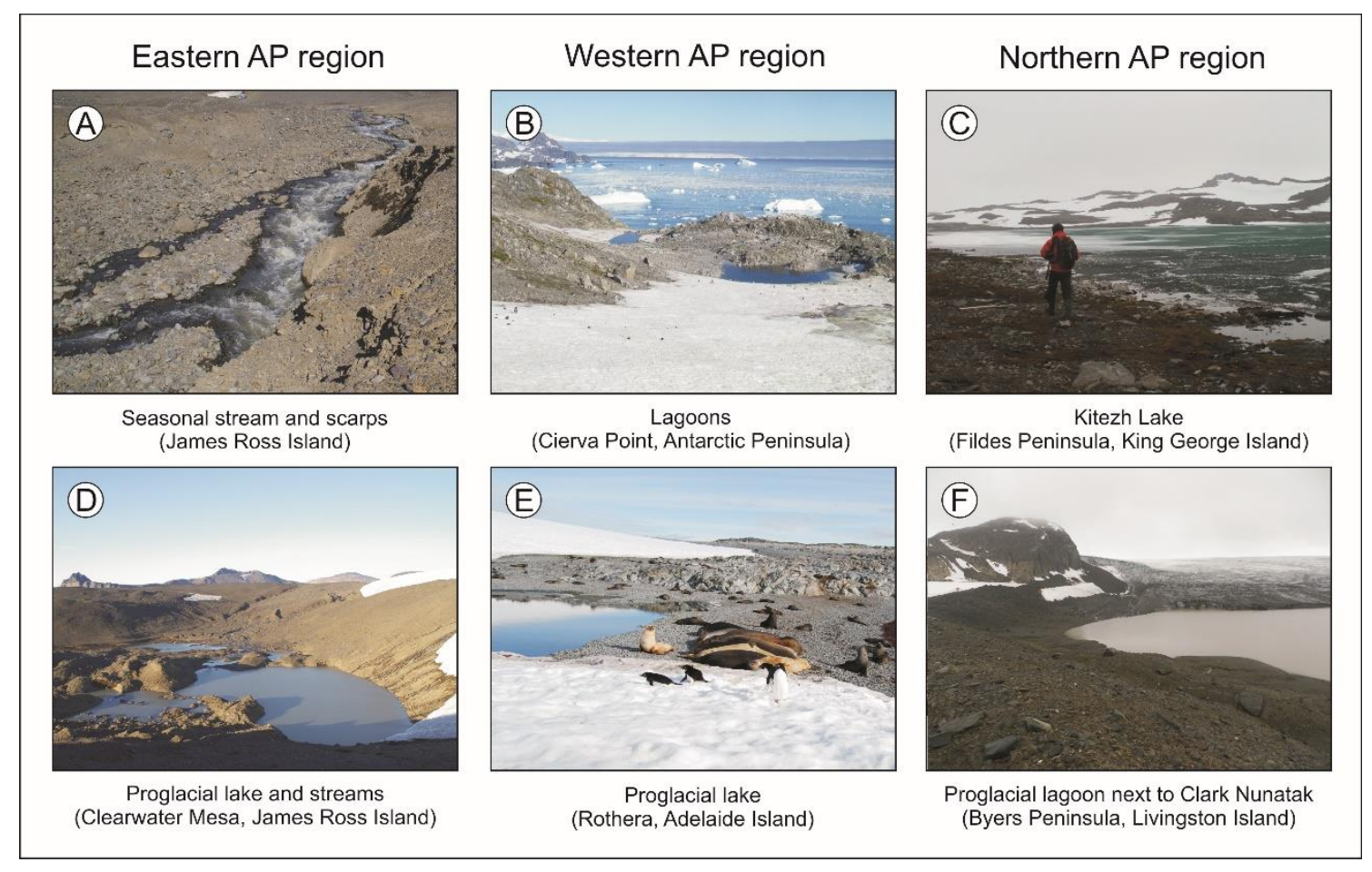

Figure 5. Examples of alluvial and lacustrine dynamics related to past $(A, B, C)$ and recent (D, E, F) paraglacial responses.

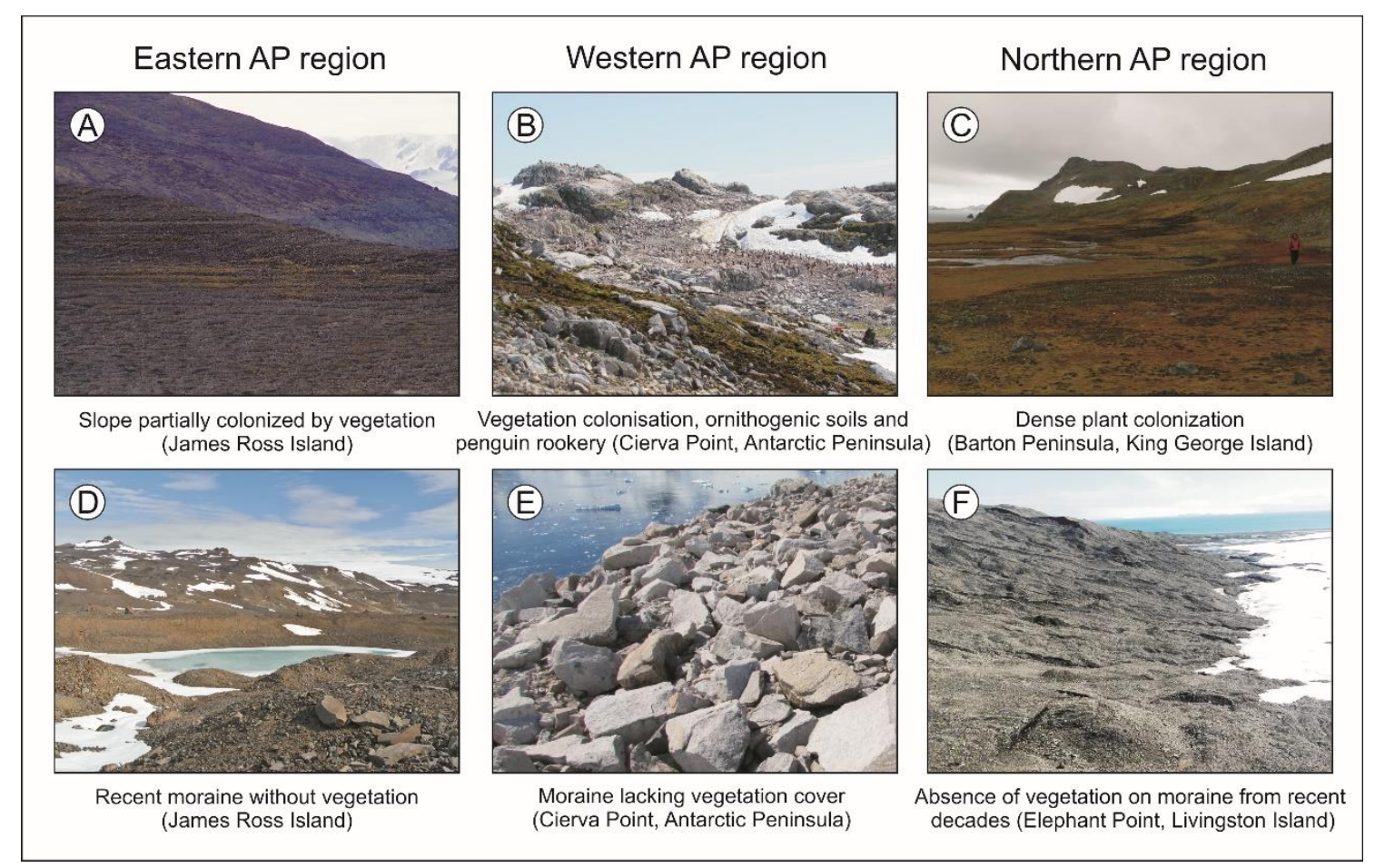

Figure 6. Examples of geoecological processes related to past (A, B, C) and recent (D, E, F) paraglacial responses. 


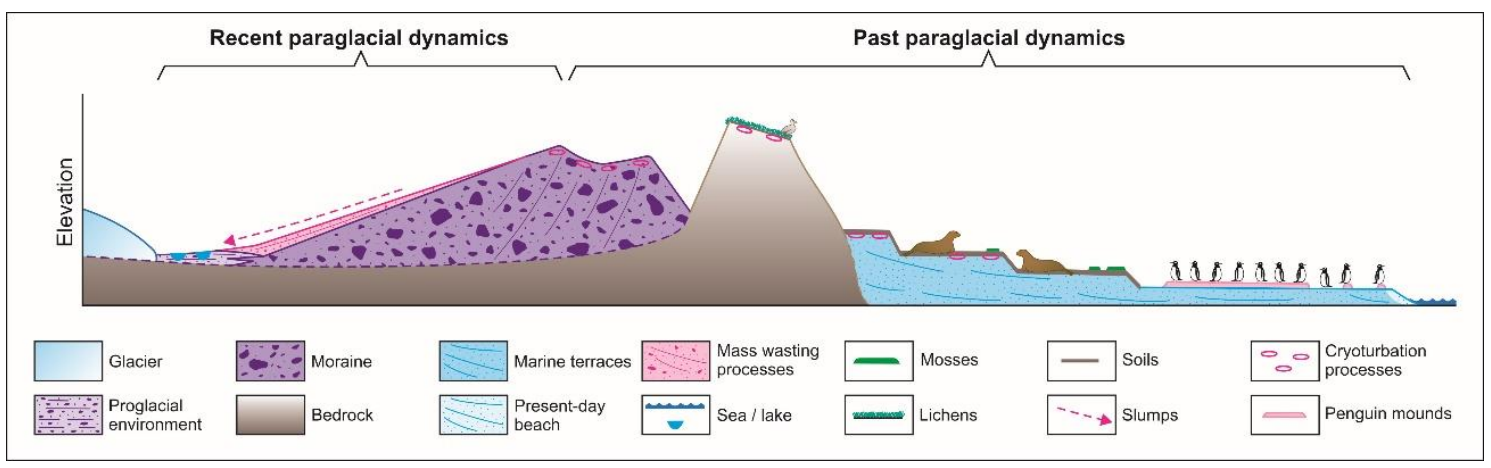

Figure 7. Synthetic representation of past and recent paraglacial responses in the AP region. 
Table 1. Coastline adjustment related to paraglacial dynamics in the AP region.

\begin{tabular}{|c|c|c|c|c|c|c|}
\hline \multirow[t]{2}{*}{ Region } & \multicolumn{3}{|c|}{ Past processes } & \multicolumn{3}{|c|}{ Recent processes } \\
\hline & Processes/landforms & Area/ Chronology & References & Processes/landforms & Area & References \\
\hline Western AP & $\begin{array}{l}\text { Highest marine terraces from } \\
\qquad 40.8 \text { to } 40.5 \mathrm{~m} \\
\begin{array}{c}\text { At least } 5 \text { levels of Holocene } \\
\text { raised beaches between } 22.2 \\
\text { and } 4.5 \mathrm{~m} \\
\text { Rate of uplift between } 2.7 \\
\mathrm{~mm} \text { yr-1 to } 4.1 \mathrm{~mm} \text { yr-1 }\end{array} \\
\begin{array}{l}\text { Higher roundness of boulders } \\
\text { related to periods of higher } \\
\text { wave activity }\end{array}\end{array}$ & $\begin{array}{c}\text { Pourquoi-Pas Island, } \\
\text { Horseshoe Island / After } 9 \text { ka } \\
\text { BP } \\
\text { Antarctic Peninsula; Rothera } \\
\text { and Anchorage Island } \\
\text { Pourquoi-Pas Island, } \\
\text { Horseshoe Island; Rothera } \\
\text { and Anchorage Island / } \\
\text { Between } 7.3 \text { and } 2.7 \text { ka BP } \\
\\
\text { 8.8 ka BP / Calmette Bay } \\
\text { Horseshoe Island / } 6 \text { and } 2.3 \\
\text { ka BP } \\
\text { Rothera and Anchorage } \\
\text { Island / } 3.5 \text { and } 2.4 \text { ka BP }\end{array}$ & $\begin{array}{l}\text { Hodgson et al., } 2013 \\
\text { Bentley et al., 2009; } \\
\text { Guglielmin et al., 2012 } \\
\text { Guglielmin et al., 2012; } \\
\text { Hodgson et al., 2013 } \\
\\
\text { Hodgson et al., 2013 } \\
\text { Bentley et al., 2005; } \\
\text { Guglielmin et al., 2012 }\end{array}$ & $\begin{array}{l}\text { Numerous glaciers show stable } \\
\text { ice-front positions or even some } \\
\text { advance } \\
\text { Locally, pronounced glacial } \\
\text { retreats have also been recorded, } \\
\text { but they did not affect the } \\
\text { coastline }\end{array}$ & $\begin{array}{l}\text { Along the west coast of the } \\
\text { AP }\end{array}$ & 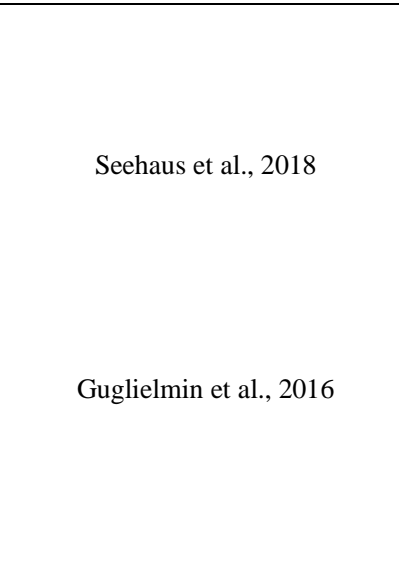 \\
\hline Eastern AP & $\begin{array}{c}\text { Development of marine } \\
\text { terraces } \\
\text { - isostatic uplift up to ca } 30 \\
\mathrm{~m} \\
\text { - isostatic uplift up to ca } 15 \\
\mathrm{~m}\end{array}$ & $\begin{array}{l}\text { JRI - Ulu Peninsula } \\
\text { Beak Island }\end{array}$ & $\begin{array}{l}\text { Hjort et al., } 1997 \\
\text { Roberts et al., } 2011\end{array}$ & $\begin{array}{c}\text { Breakup of ice shelves and } \\
\text { opening of coastal areas } \\
\begin{array}{c}\text { Sand and gravel spits and modern } \\
\text { beaches formation }\end{array}\end{array}$ & $\begin{array}{c}\text { Prince Gustav Ice Shelf } \\
\text { Larsen A Ice Shelf } \\
\text { Larsen B Ice Shelf } \\
\text { JRI }\end{array}$ & $\begin{array}{c}\text { Skvarca et al., 1995 } \\
\text { Cook \& Vaughan, } 2010 \\
\\
\text { Strelin \& Malagnino, 1992; } \\
\text { Davies et al., 2013 } \\
\text { Mlčoch et al., } 2017\end{array}$ \\
\hline $\begin{array}{l}\text { Northern AP and } \\
\text { surrounding areas }\end{array}$ & $\begin{array}{l}\text { Development of a sequence } \\
\text { of 5-7 raised beaches } \\
\text { (relative heights above sea } \\
\text { level from } 2 \text { to } 20 \mathrm{~m} \text { ) during } \\
\text { the Holocene showing a } \\
\text { maximum glacio-isostatic } \\
\text { uplift of ca } 20 \mathrm{~m} \text {. } \\
\text { Center of maximum uplift } \\
\text { situated in the SSI between } \\
\text { Greenwich and Robert } \\
\text { islands }\end{array}$ & $\begin{array}{l}\text { SSI / Uplift rates of } 2.2 \text { and } \\
4.8 \mathrm{~mm} \text { yr-1 over the last } \sim 7 \\
\text { ka BP. Age of the highest } \\
\text { raised beaches of } 7.5-7 \mathrm{ka} \\
\text { BP. }\end{array}$ & $\begin{array}{c}\text { John \& Sudgen, 1971; } \\
\text { Hanson, 1979; Del Valle et } \\
\text { al., 2002; Bentley et al., } \\
\text { 2005a; Fretwell et al., 2010; } \\
\text { Hall, 2010; Watcham et al., } \\
2011\end{array}$ & $\begin{array}{l}\text { Formation of tombolos and } \\
\text { present-day beaches, and } \\
\text { discharge of sediments from new } \\
\text { proglacial environments to } \\
\text { marine environments }\end{array}$ & $\begin{array}{l}\text { Livingston (Byers, } \\
\text { Elephant Point), Deception }\end{array}$ & $\begin{array}{c}\text { López-Martínez et al., 1996; } \\
\text { López-Martínez \& Serrano, 2002; } \\
\text { Oliva \& Ruiz-Fernández, 2015, } \\
2017\end{array}$ \\
\hline
\end{tabular}


Table 2. Permafrost, periglacial processes and mass movements related to paraglacial dynamics in the AP region.

\begin{tabular}{|c|c|c|c|c|c|c|}
\hline \multirow{2}{*}{ Region } & \multicolumn{3}{|c|}{ Past processes } & \multicolumn{3}{|c|}{ Recent processes } \\
\hline & Processes/landforms & Area/ Chronology & References & Processes/landforms & Area & References \\
\hline Western AP & $\begin{array}{l}\text { Sporadic permafrost at } \\
\text { elevations above 100- } \\
180 \text { m a.s.l. } \\
\text { Continuous permafrost } \\
\\
\text { Permafrost strongly } \\
\text { controlled by snow } \\
\text { accumulation } \\
\text { Stone-banked } \\
\text { solifluction lobes and } \\
\text { terracettes are common } \\
\text { features }\end{array}$ & $\begin{array}{l}\text { Palmer Archipelago and } \\
\text { Biscoe Islands } \\
\text { Rothera area } \\
\text { WAP } \\
\text { WAP }\end{array}$ & $\begin{array}{l}\text { Bockheim et al., } 2013 \\
\text { Guglielmin et al., } 2014 \\
\text { Bockheim et al., } 2013 \\
\text { Guglielmin et al., } 2014\end{array}$ & $\begin{array}{l}\text { Thermal weathering and thermal } \\
\text { shock are very effective in the } \\
\text { newly exposed areas } \\
\text { Widespread distribution of } \\
\text { permafrost (mainly in strong } \\
\text { degradation) favour mass wasting } \\
\text { processes (rock falls, rock } \\
\text { landslides, debris flows, slumps, } \\
\text { etc.) }\end{array}$ & WAP & Hall, 1997 \\
\hline Eastern AP & $\begin{array}{l}\text { Mass processes like } \\
\text { landslides, debris flows } \\
\text { and rockfalls } \\
\text { Talus slopes, scree } \\
\text { slopes, protalus rampart } \\
\text { Active rock glaciers } \\
\\
\text { Rock glaciers, sorted } \\
\text { grounds, thermokarst } \\
\text { depresions }\end{array}$ & $\begin{array}{c}\text { JRI - Ulu Peninsula } \\
\text { JRI - Ulu Peninsula, Vega } \\
\text { Island } \\
\text { JRI - Ulu Peninsula, } \\
\text { Tumbledown Cliffs, Rink } \\
\text { Crags } \\
\text { Vega Island, Devil Bay }\end{array}$ & 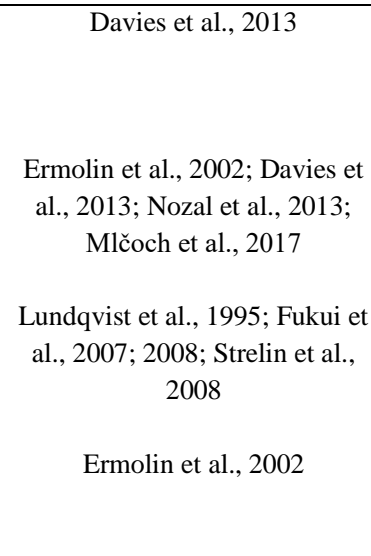 & $\begin{array}{l}\text { Recent process limited to scree on } \\
\text { newly exposed areas }\end{array}$ & JRI - Ulu Peninsula & Davies et al., 2013 \\
\hline $\begin{array}{l}\text { Northern AP and } \\
\text { surrounding areas }\end{array}$ & $\begin{array}{l}\text { Nine rock glaciers and } \\
\text { eleven main protalus }\end{array}$ & $\begin{array}{l}\text { King George (Fildes, Keller, } \\
\text { Italian Valley, Ferguson, } \\
\text { Tyreell, Hennequin, Loggia } \\
\text { Corrie,), Livingston (Hurd, } \\
\text { Mackay, Renier), Robert } \\
\text { (Coppermine), Nelson } \\
\text { (Standbury)/ Three }\end{array}$ & $\begin{array}{l}\text { Serrano \& López-Martínez, } \\
\text { 2000; López-Martínez et al., }\end{array}$ & $\begin{array}{c}\text { Several slow and rapid mass } \\
\text { movements related with presence } \\
\text { of permafrost/seasonal frost: } \\
\text { mudflows, debris flows, rockfalls, } \\
\text { landslides, solifluction landforms }\end{array}$ & $\begin{array}{l}\text { SSI - King George (Fildes), } \\
\text { Livingston (Byers, Elephant } \\
\text { Point), Deception; NAP }\end{array}$ & $\begin{array}{l}\text { López-Martínez et al., 1996, 2012; López- } \\
\text { Martínez \& Serrano, 2002; Serrano et al., } \\
\text { 2002; Bockheim et al., 2013; Michel et al., } \\
\text { 2014; Oliva \& Ruiz-Fernández, 2015, 2017; } \\
\text { Ruiz-Fernández \& Oliva, 2016; Ruiz- } \\
\text { Fernández et al., 2016 }\end{array}$ \\
\hline
\end{tabular}




\begin{tabular}{|c|c|c|c|c|c|c|}
\hline & Inactive blockstreams & $\begin{array}{c}\text { generations of rock glaciers } \\
\text { formed: 1) post-last major } \\
\text { deglaciation, 2) between } 2 \mathrm{ka} \\
\text { BP and pre-LIA, 3) during } \\
\text { the LIA } \\
\text { SSI; Byers Peninsula / } \\
\text { Presence of inactive } \\
\text { blockstreams without datings } \\
\text { SSI - King George (Fildes, } \\
\text { Barton, Weaver), Livingston } \\
\text { (Byers, Elephant Point), } \\
\text { Deception } \\
\text { South Orkneys islands - } \\
\text { Signy }\end{array}$ & $\begin{array}{l}\text { López-Martínez et al., 1996, } \\
\text { 2012; López-Martínez \& } \\
\text { Serrano, 2002; Serrano \& } \\
\text { López-Martínez, 1997a, 1997b, } \\
\text { 1998, 2004; Serrano et al., } \\
\text { 1996, 2002; Guglielmin et al., } \\
\text { 2008; Michel et al., 2014; Oliva } \\
\text { \& Ruiz-Fernández, 2015, 2017; } \\
\text { Ruiz-Fernández \& Oliva, 2016; } \\
\text { Ruiz-Fernández et al., } 2016\end{array}$ & $\begin{array}{l}\text { Active patterned ground features: } \\
\text { stone sorted-circles, stone stripes, } \\
\text { stone fields, stone polygons, } \\
\text { micropolygons, earth hummocks, } \\
\text { mudboils } \\
\text { Active rock glaciers, protalus } \\
\text { lobes and blockstreams } \\
\text { Existence of permafrost in } \\
\text { recently deglaciated areas related } \\
\text { with cold-based glaciers }\end{array}$ & $\begin{array}{c}\text { SSI - King George (Fildes, } \\
\text { Barton, Weaver), Livingston } \\
\text { (Byers, Elephant Point), } \\
\text { Deception, } \\
\text { South Orkneys islands - Signy } \\
\\
\text { SSI - King George (Fildes, } \\
\text { Barton, Weaver, Keller), } \\
\text { Livingston (Hurd, Byers, Barnard } \\
\text { Point), Robert (Coppermine), } \\
\text { Nelson (Standbury) } \\
\text { SSI - Livingston (Byers, Elephant } \\
\text { Point) }\end{array}$ & $\begin{array}{l}\text { López-Martínez et al., 1996, 2012; López- } \\
\text { Martínez \& Serrano, 2002; Serrano \& López } \\
\text { Martínez, 1997a, 1997b, 1998, 2004; Serrano } \\
\text { et al., 1996, 2002; Guglielmin et al., 2008; } \\
\text { Michel et al., 2014; Oliva \& Ruiz-Fernández } \\
\text { 2015, 2017; Ruiz-Fernández \& Oliva, 2016; } \\
\text { Ruiz-Fernández et al., } 2016\end{array}$ \\
\hline
\end{tabular}


Table 3. Alluvial /lacustrine dynamics related to paraglacial dynamics in the AP region.

\begin{tabular}{|c|c|c|c|c|c|c|}
\hline \multirow[t]{2}{*}{ Region } & \multicolumn{3}{|c|}{ Past processes } & \multicolumn{3}{|c|}{ Recent processes } \\
\hline & Processes/landforms & Area/ Chronology & References & Processes/landforms & Area & References \\
\hline Western AP & $\begin{array}{c}\text { Increase of productivity in the } \\
\text { Narrows Lake indicating warm } \\
\text { periods }\end{array}$ & $\begin{array}{c}\text { Marguerite Bay / Between } 9260 \\
\text { and } 8.5 \mathrm{ka} \mathrm{BP} \text {, between } 6.2 \text { and } 2 \\
\text { ka BP, after } 2.1 \mathrm{ka} \mathrm{BP} \text {, and } \\
\text { between } 540 \text { and } 380 \mathrm{cal} \text { yr BP }\end{array}$ & Hodgson et al., 2013 & & & \\
\hline Eastern AP & $\begin{array}{c}\text { Formation of lakes after } \\
\text { deglaciation. Different types of } \\
\text { lakes according to their origin } \\
\text { and geomorphological position: } \\
\text { coastal lakes, lakes on volcanic } \\
\text { mesas and other erosional } \\
\text { surfaces, lakes in old moraines, } \\
\text { lakes in young moraines, cirque } \\
\text { lakes }\end{array}$ & $\begin{array}{l}\text { JRI, Ulu Peninsula } \\
\text { JRI, Lagoons Mesa } \\
\text { JRI, Clearwater Mesa } \\
\text { Beak Island } \\
\text { Vega Island }\end{array}$ & $\begin{array}{l}\text { Ingólfsson et al., 1992; Björk } \\
\text { et al., 1996; Hjort et al., } \\
\text { 1997; Nedbalová et al., } 2013 \\
\text { Lecomte et al., } 2016 \\
\text { Roman et al., in review } \\
\text { Sterken et al., } 2012 \\
\text { Lecomte et al., 2016; Píšková } \\
\text { et al., } 2017\end{array}$ & $\begin{array}{l}\text { Kettle, cirque and unstable moraine lakes } \\
\text { Moraine lake development and outburst }\end{array}$ & $\begin{array}{l}\text { JRI, Ulu Peninsula } \\
\text { JRI, Ulu Peninsula } \\
\text { JRI, Abernethy Flats }\end{array}$ & $\begin{array}{l}\text { Carrivick et al., 2012; Davies et } \\
\text { al., 2013; Nedbalová et al., } \\
2013 \\
\text { Sone et al., } 2008\end{array}$ \\
\hline & River network formation & JRI, Ulu Peninsula & $\begin{array}{l}\text { Davies et al., 2013; } \\
\text { Kavan et al., } 2017\end{array}$ & & & \\
\hline $\begin{array}{l}\text { Northern AP and } \\
\text { surrounding areas }\end{array}$ & $\begin{array}{l}\text { Formation of lakes and semi- } \\
\text { permanent coastal lagoons } \\
\text { favouring changes on terrestrial } \\
\text { vs aquatic ecosystem dynamics } \\
\text { in these areas }\end{array}$ & $\begin{array}{c}\text { SSI - King George (Fildes), } \\
\text { Livingston (Byers, Elephant } \\
\text { Point) / since the Early Holocene } \\
\text { onwards }\end{array}$ & $\begin{array}{l}\text { Toro et al., 2013; Oliva et al., } \\
\text { 2016, Oliva \& Ruiz- } \\
\text { Fernández, } 2017\end{array}$ & $\begin{array}{l}\text { Hydrologic changes with the formation of } \\
\text { kettle-lakes, seasonal streams, lagoons, } \\
\text { lakes, alluvial fans in proglacial areas }\end{array}$ & $\begin{array}{l}\text { SSI - King George } \\
\text { (Fildes), Livingston } \\
\text { (Byers, Elephant Point), } \\
\text { Deception Island }\end{array}$ & $\begin{array}{l}\text { López-Martínez et al., 1996, } \\
\text { 2012; López-Martínez \& } \\
\text { Serrano, 2002; Oliva \& Ruiz- } \\
\text { Fernández, 2015, } 2017 .\end{array}$ \\
\hline & $\begin{array}{l}\text { Early stage of drainage network } \\
\text { related to past local glacial spots }\end{array}$ & SSI - Livingston (Byers) & Mink et al., 2014 & $\begin{array}{c}\text { Early stage of drainage network related to } \\
\text { past local glacial spots }\end{array}$ & SSI - Livingston (Byers) & Mink et al., 2014 \\
\hline
\end{tabular}


Table 4. Geoecological responses related to paraglacial dynamics in the AP region.

\begin{tabular}{|c|c|c|c|c|c|c|}
\hline \multirow{2}{*}{ Region } & \multicolumn{3}{|c|}{ Past processes } & \multicolumn{3}{|c|}{ Recent processes } \\
\hline & Processes & Area/ Chronology & References & Processes & Area & References \\
\hline Western AP & $\begin{array}{l}\text { Vegetation succession with } \\
\text { increasing cover and changes of } \\
\text { floristic composition on } \\
\text { deglaciated areas } \\
\text { Vegetation cover is denser in the } \\
\text { oldest tundra areas. Increase of } \mathrm{C} \text {, } \\
\mathrm{N} \text {, and P under vegetation cover } \\
\text { Permafrost aggradation after } \\
\text { deglaciation promotes the } \\
\text { development and persistence up to } \\
\text { millennia of moss peat banks } \\
\text { Moss individuals survived through } \\
\text { cryptobiosis during six centuries of } \\
\text { cold-based glacier burial and were } \\
\text { alive after re-exposure } \\
\text { Occupation cycles of fauna } \\
\text { correlate with glacial retreat stages }\end{array}$ & $\begin{array}{c}\text { Deglaciated terrains at } \\
\text { Argentine and Comer Island; } \\
\text { Anvers Island } \\
\text { Anvers / ice-free for several } \\
\text { hundred years } \\
\text { Anvers Island } \\
\text { Alexander Island } \\
\text { glacier forefield at Rothera } \\
\text { Point } \\
\\
\text { Marguerite Bay / } \\
\text { koils formed }>6 \\
\text { ornithogenic } 6 \\
\text { Palmer Region/ penguin } \\
\text { occupation began } ~ 600 \text { cal yr } \\
\text { BP }\end{array}$ & $\begin{array}{l}\text { Strauss et al., } 2009 \\
\text { Smith } 1982 \\
\text { Royles et al., } 2013\end{array}$ & $\begin{array}{l}\text { Vegetation colonization starts within } 20-30 \\
\text { years since deglaciation } \\
\text { Cryoturbation affects the colonization of } \\
\text { recently deglaciated areas } \\
\text { Coarse textured cryosols with a low content in } \\
\text { soil organic matter form in recently deglaciated } \\
\text { terrain } \\
\text { Soils with different chemistry exhibit similar } \\
\text { bacterial composition } \\
\text { Mineral soils containing greater soil moisture } \\
\text { form near the glacier fronts, with active } \\
\text { microbial community } \\
\text { Higher development of soils affected by faunal } \\
\text { activity, with significant } \mathrm{N} \text { enrichment }\end{array}$ & $\begin{array}{l}\text { Anvers Island } \\
\text { Alexander Island } \\
\text { Alexander } \\
\text { Alexander Island } \\
\text { Anvers } \\
\text { Anchorage }\end{array}$ & $\begin{array}{c}\text { Smith } 1995 \\
\text { Engelen et al., 2008, } 2010 \\
\text { Engelen et al., } 2008 \\
\text { Newsham et al., } 2010 \\
\text { Strauss et al., 2009, } 2012\end{array}$ \\
\hline Eastern AP & $\begin{array}{c}\text { Alteration of guano layer on relict } \\
\text { ornithogenic soils by chemical and } \\
\text { mechanical weathering, mass } \\
\text { movements and frost processes } \\
\text { Hundreds of seal carcasses that are } \\
\text { important transporting agents of } \\
\text { nutrients } \\
\end{array}$ & $\begin{array}{l}\text { Seymour Island } \\
\text { James Ross Island } \\
\text { Archipielago }\end{array}$ & $\begin{array}{c}\text { Tatur, } 1989 \\
\\
\text { Nelson et al., 2008; Negrete } \\
\text { et al., 2011, 2015; Nývlt et } \\
\text { al., 2016 } \\
\end{array}$ & $\begin{array}{l}\text { Periglacial processes limiting vegetation } \\
\text { development } \\
\text { Higher development of soils affected by faunal } \\
\text { activity }\end{array}$ & $\begin{array}{l}\text { James Ross (Lachman Crags, } \\
\text { Rink Plateau) } \\
\text { Seymour; Ice-free terrains in } \\
\text { Hope Bay }\end{array}$ & $\begin{array}{l}\text { Souza et al., 2014; Pereira et al., } \\
\text { 2013; Schaefer et al., } 2015\end{array}$ \\
\hline $\begin{array}{l}\text { Northern AP } \\
\text { and surrounding } \\
\text { areas }\end{array}$ & $\begin{array}{c}\text { Ecological succession with } \\
\text { pioneer/early/late (climax) } \\
\text { communities and increase of plant } \\
\text { species diversity and coverage } \\
\text { with deglaciation age } \\
\text { Vegetation succession with }\end{array}$ & $\begin{array}{l}\text { Deglaciated areas since LGM } \\
\text { to XX century at Signy Island }\end{array}$ & $\begin{array}{c}\text { Smith 1995; Favero-Longo } \\
\text { et al., } 2012\end{array}$ & $\begin{array}{l}\text { Vegetation colonization starts within 20-30 } \\
\qquad \text { years since deglaciation } \\
\text { Coarse textured cryosols with a low content in } \\
\text { soil organic matter form in recently deglaciated } \\
\text { terrain }\end{array}$ & $\begin{array}{c}\text { SSI - King Geroge (Fildes), } \\
\text { Ardley Island. } \\
\text { Close to Arctowski Station }\end{array}$ & $\begin{array}{l}\text { Sancho \& Valladares 1993; } \\
\text { Valladares \& Sancho, } 1995 \\
\text { Blume et al., 2002, Michel et al., } \\
\text { 2014 }\end{array}$ \\
\hline
\end{tabular}




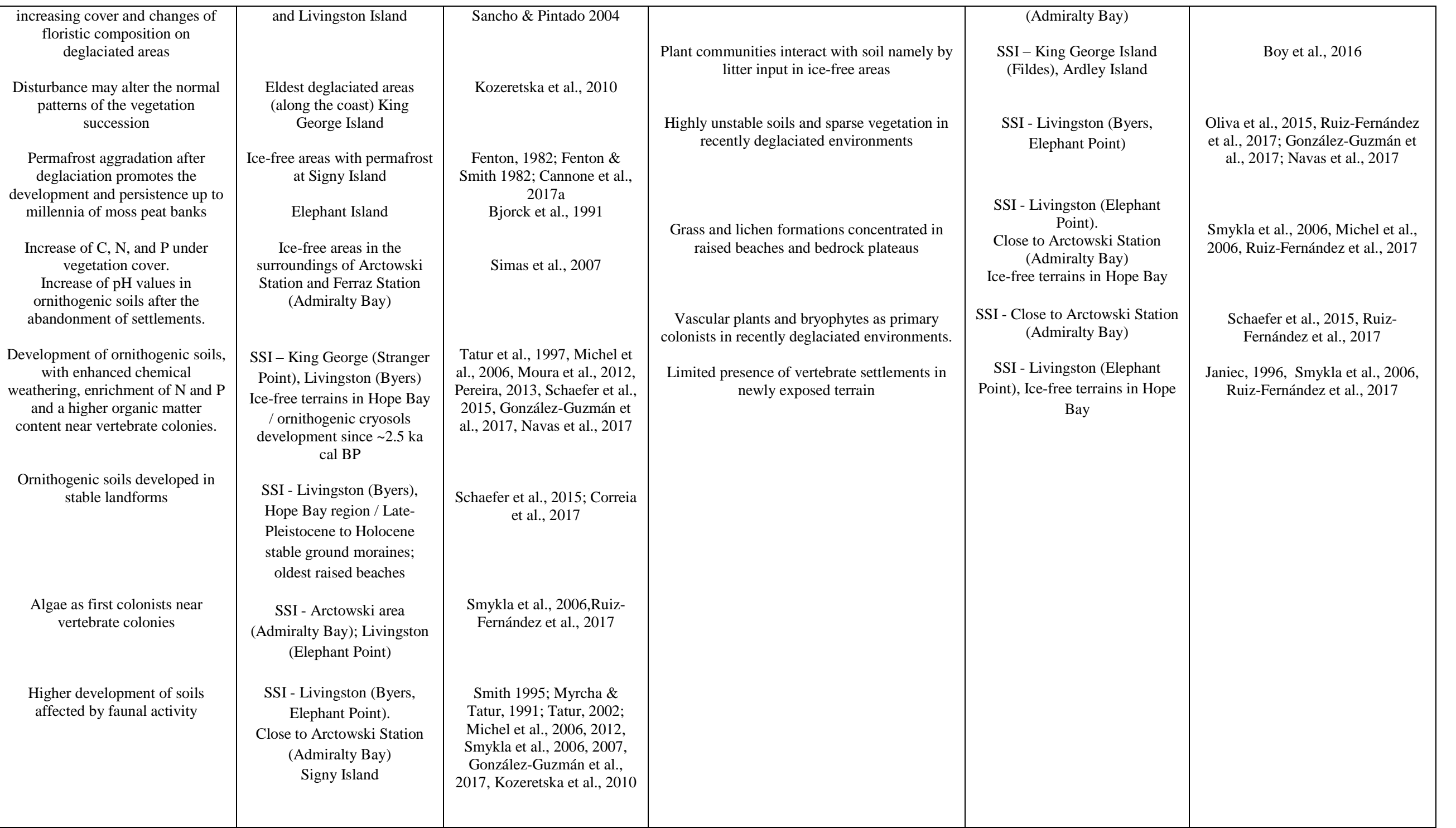

